WHO/MAL/98.1084

توزيع محدود است

نسخه اصلى به زبان انكليسى است

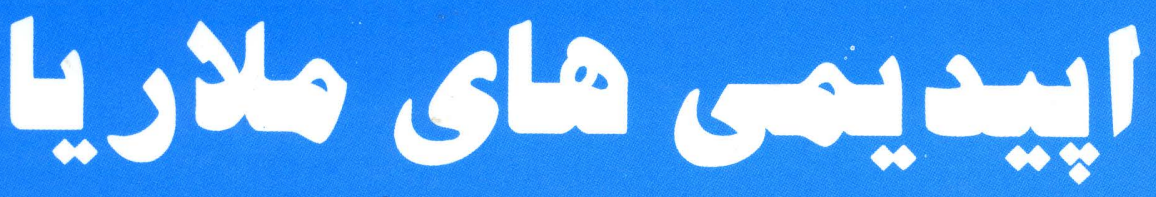

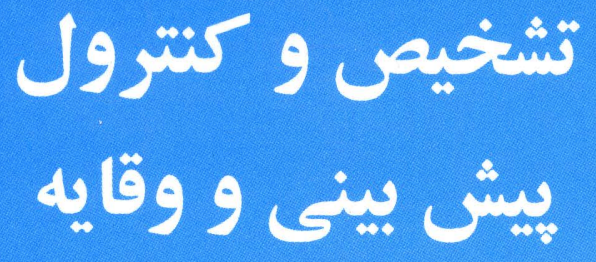

JA Najera, RL Kouznetzsov and C Delacollette

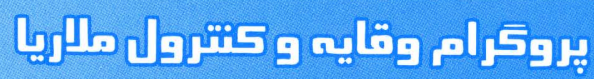
سازمان مسى بطان

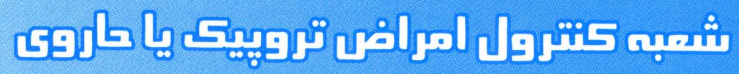


WHO/MAL/98.1084 توزيع محدود أست

نسخه اصلى به زبان انغليسى است

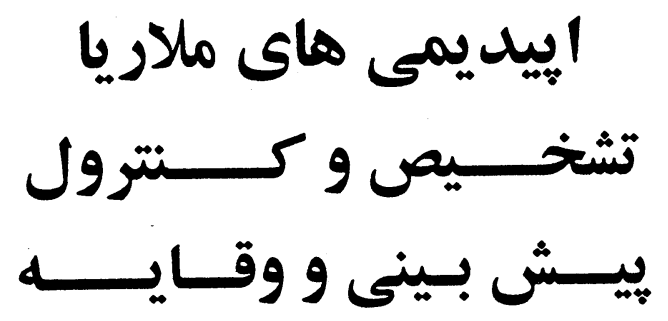

JA. Najera. RL Kouznetzsov and C Delacollette

Wast

سازمان صحى جهان

شعبه كنترول امراض حاروى يا تروييك

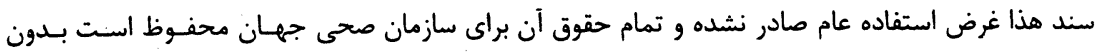

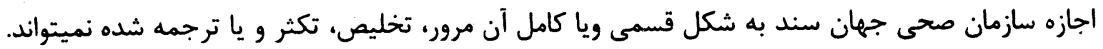

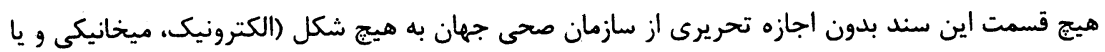

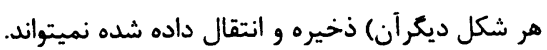
مؤلفين كه نظريات شان در سند تذكر داده شده مسؤوليت كامل خود شان است. 
فهرست مندرجات

$$
\text { لست كراف ها لساول }
$$

1
1
$r$
$r$
$r$
0
$r$
9
1.
11
$r$.

rr

rT

rr

YF

ro

ro

rY

YY

rV

YA

rA

TA

$r$.

ri

rI

rT

1
خصوصيات عمومى اييديمى هاى ملاريا

1. مقدمه

S II

ه. شناسائى و بررسى إيديمولوزيك وتئي

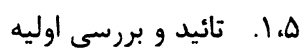

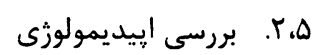

9. كنترول وضعيت هاى إيديمى ايدى

צ، أ. اصول عمومى كنترول

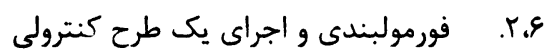

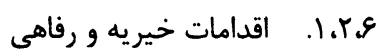

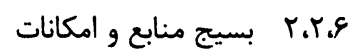

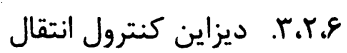

V. منجمنت يا اداره كردن مرض

V.V

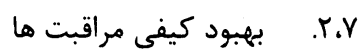

r.r. r.v

1. كنترول انتقال

1، ا منترول انقال 
rF

rF

rA

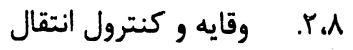

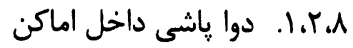

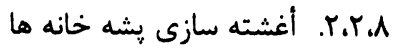

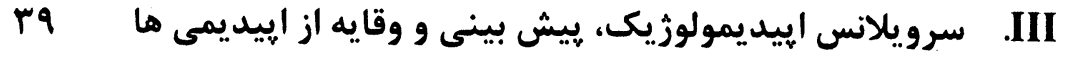

$r$.

f.

FI

fr

Fo

fo

fe

FV

fr

fq

$\Delta r$

$\Delta F$

$\Delta f$

$\Delta V$

qp

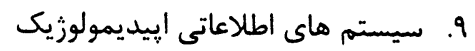

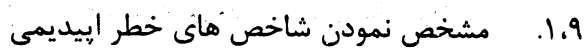

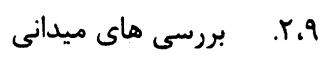

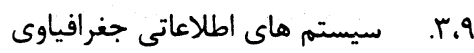

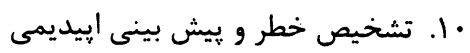

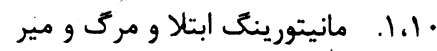

• •

r.l.

f.F.1.

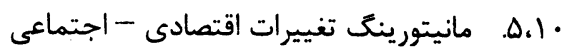

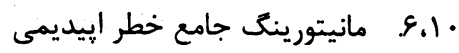

11. آمادكى عاجل و وقايه از اييديمى مانئورئ

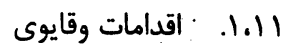




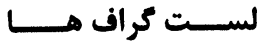

كراف ا منحنى هاى مجزا و تركيبى يك إيديمى

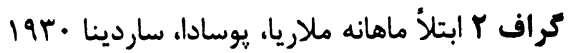

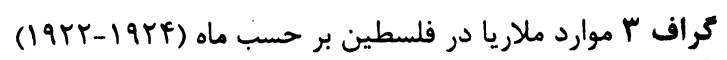

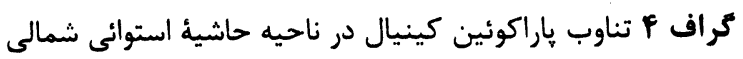
تراف ه الف ميزان مرك و ميردر اييديمى ملاريا به دليل A.albimanus كراف ها ب ميزان مرگ و مير در إيديمى ملاريا به دليل A.darlingi

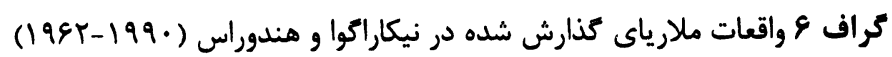
كراف V واقعات ملارياى كذارش شده در ايران (• (99-198Y)

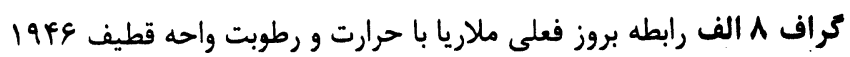

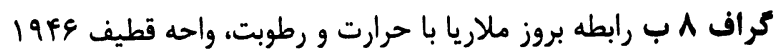
كراف 9 مصابيت و مرى و مير ثبت شده از ملاريا در ايتاليا كراف •ا واقعات ملاريا و مرى و مير ثبت شده از آن در هسيانيا

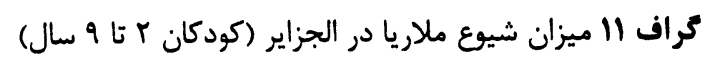
كراف rا واقعات ملاريا كذارش شده در سريلانكا كراف سا تغييرات سطح آب رودخانه انيل در خرتوم كراف F اف بارش ماهانه در خرتوم كراف ها تغييرات سطح آب رود خانه نيل در وادمدانى كراف 19 واقعات كذارش شده ملاريا - برازيل

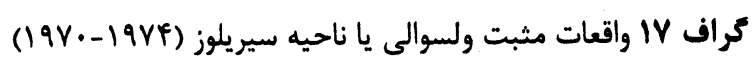

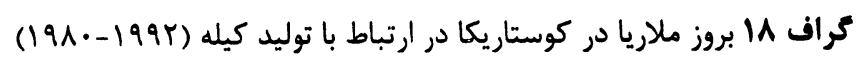

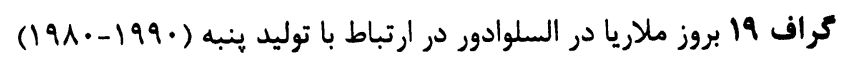

\section{لست جداول}

re جدول 1 حشره كش هاى مورد استفاده در دوا ياشى داخل امكان ef

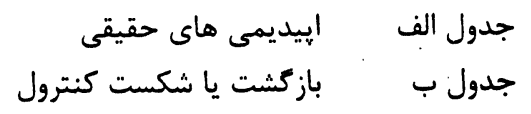




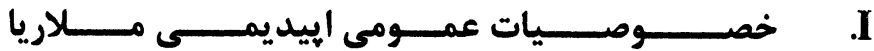 \\ I. GENERAL CHARACTERISTICS OF MALARIA EPIDEMICS}

\section{(Introduction) (1. إ) مقدمه}

ملاريا يكى از علل عمدة ابيديمى هاى بزرى كذشته بوده است. اين إيديمى ها به شكل دوره اى به تعقيب بارندكى

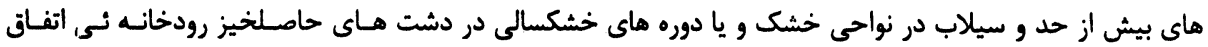

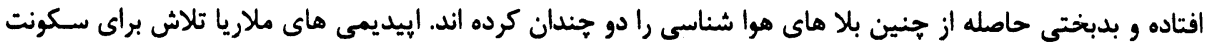

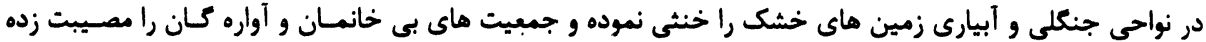

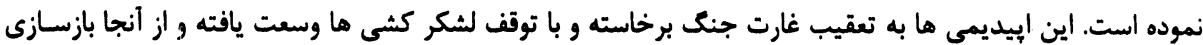
هاى سريع زندكى دهاتى را مختل نموده است.

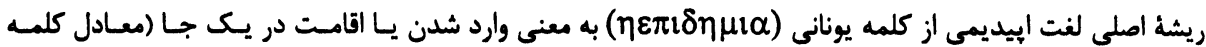
visitation

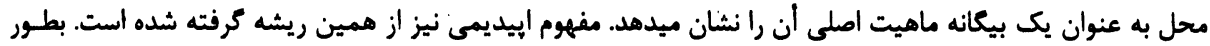

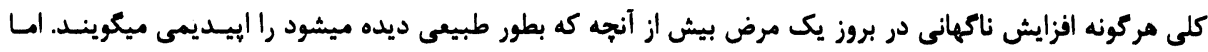

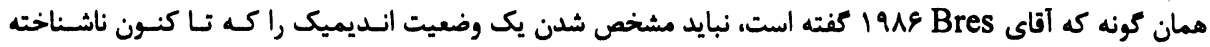

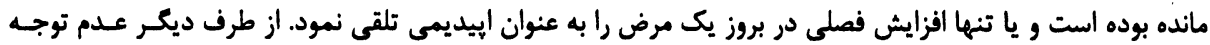

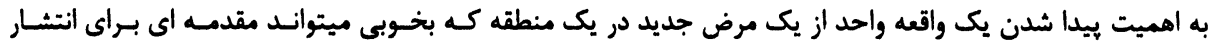
شديد واقعات بعدى باشد، نيز اشتباه خواهد بود.

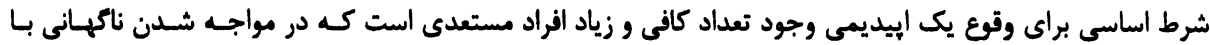

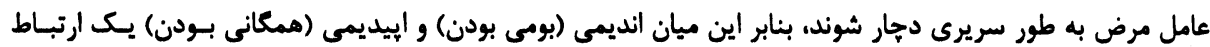

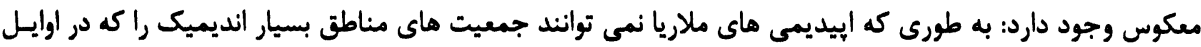

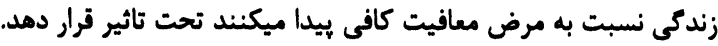

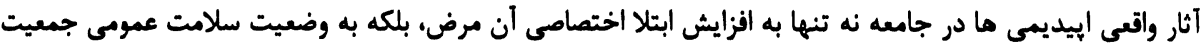

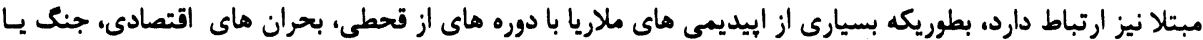

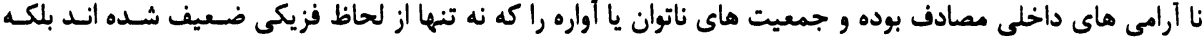

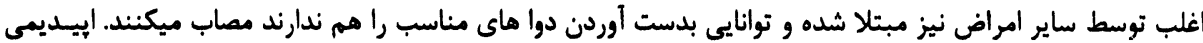

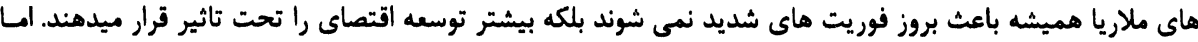

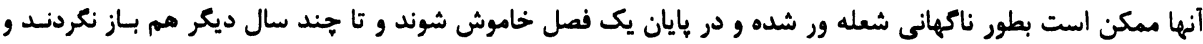

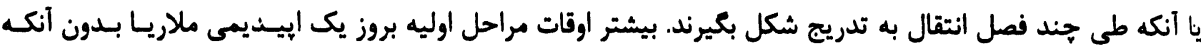

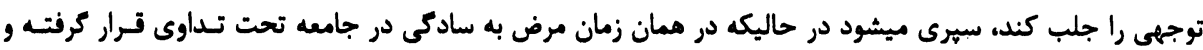

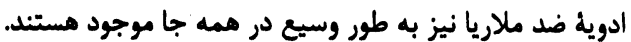




\section{WHO/MAL/98.1084}

\section{صفح}

شكل تظاهر و نحوه انتشار اييديمى هاى ملاريا بطور قابل ملاحظه اي با هم فرق ميكنند. بعضى اوقـات آنها ممكـن

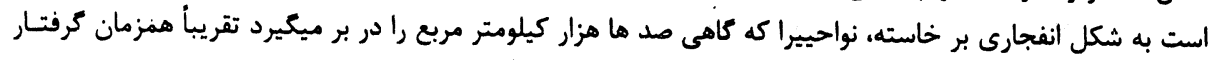

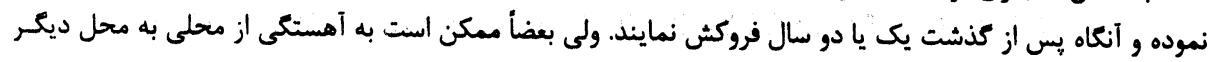

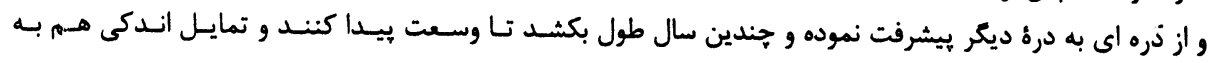
فرونشستن از خود نشان ندهند.

\section{سوابق يا تاريخهه}

ممكن است از لحاظ تاريخى نسبت دادن قطعى ملاريا با بعضى از ايبديمى هاى تب دار كذشته مشكل باشد، اما طسى

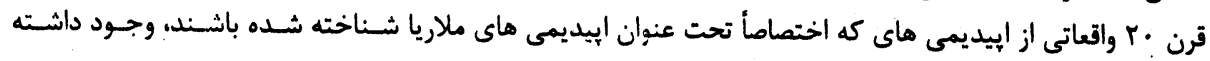

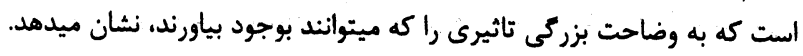

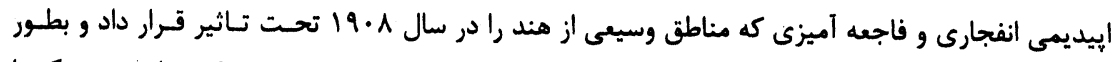

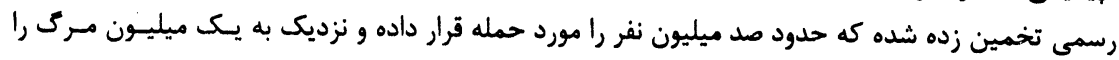
ايجاد نموده است.

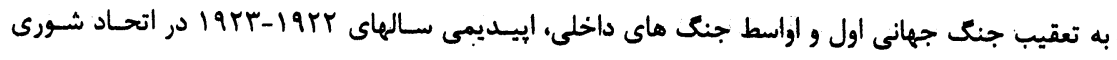

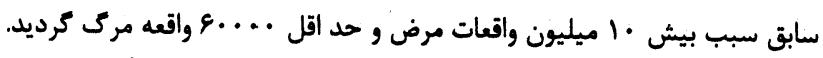

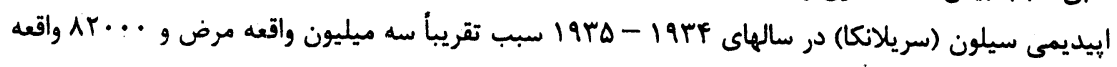
مرك كرديد.

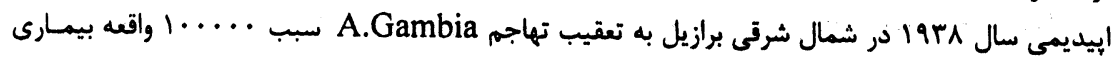

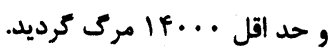

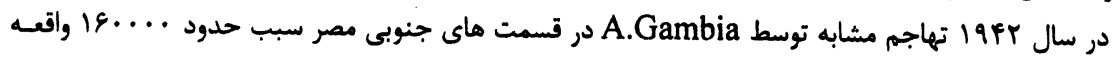

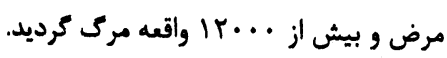

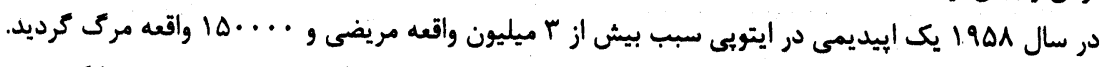

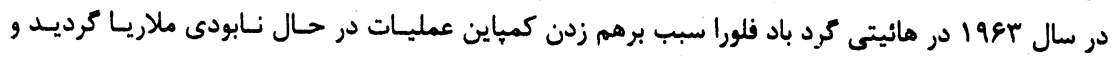

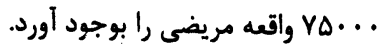

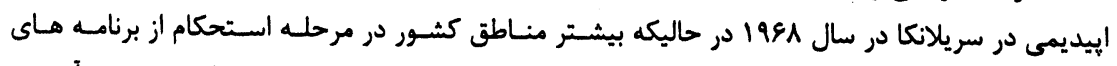

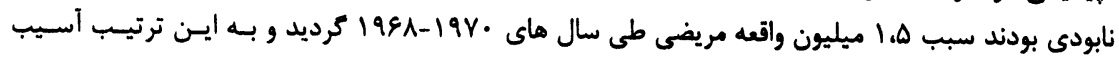

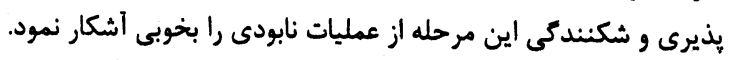

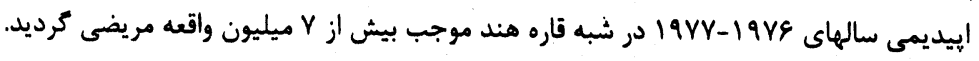

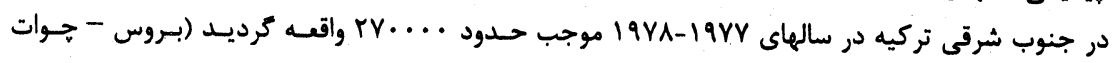

إيديمى هاى ملاريا يديده هاى صرف تاريخى نيستند. بطوريكه إيبديمى هاى شديد نيز اخيرا اتفـاق افتـاده

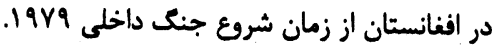

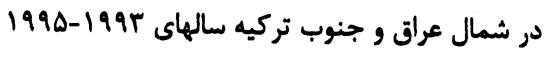




\section{WHO/MAL/98.1084}

p ص v

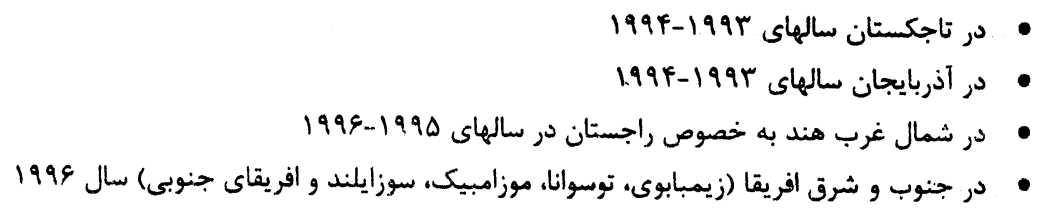

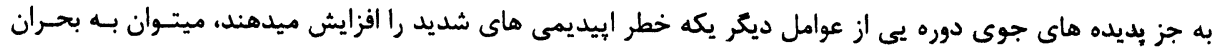

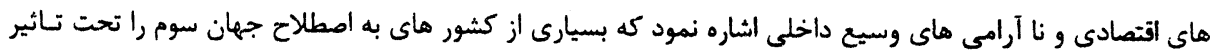
قرار טامه اند.

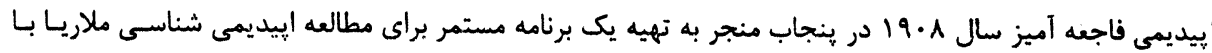

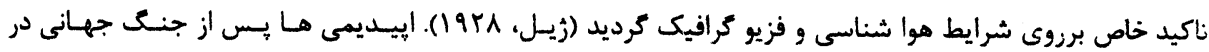

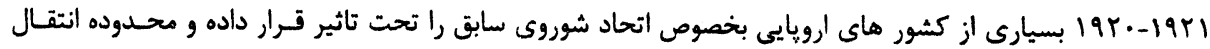

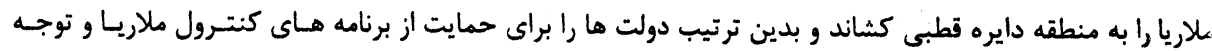

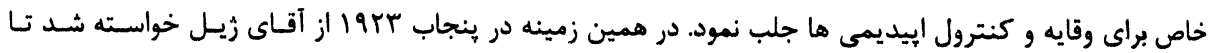

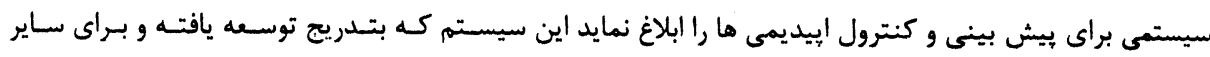

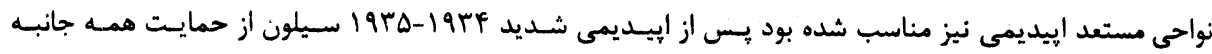

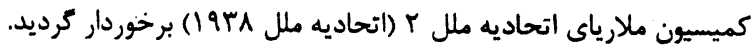

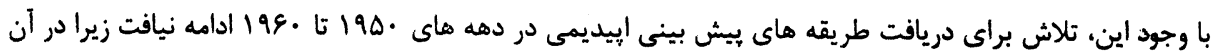

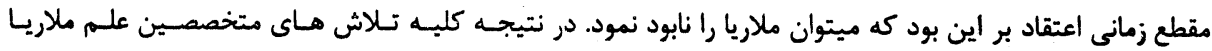

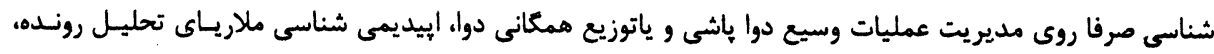
تشخيص كانون هاى ابقايى و وقايه يا حذف بازكشت انتقال متمركز كرديده بوني بودي

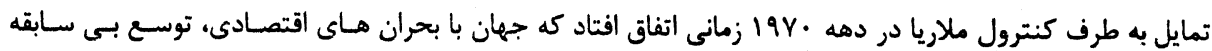

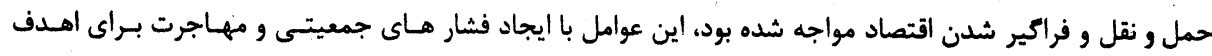

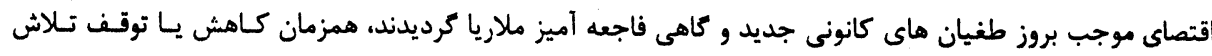

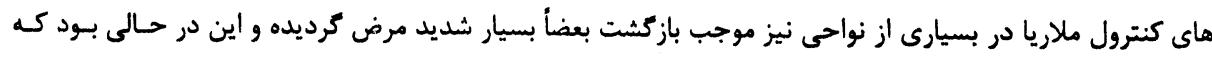

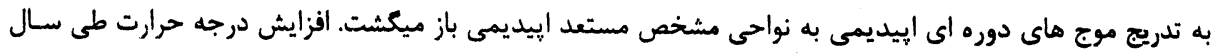

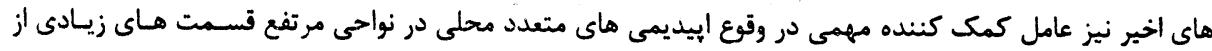
دنيا بوده است.

\section{r.l. تعين كننده هاى اصلى در ابيديمى هاى ملاريا}

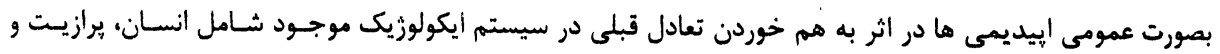

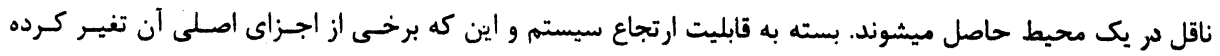

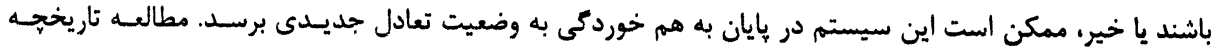

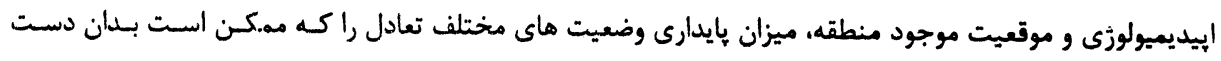

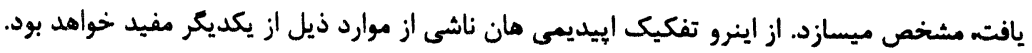


ص صفح

به هم خوردن مؤقت تعادل هايدار در يك منطقه هيهوانديميك مانند مواردى كه در نتيجه شرايط جوى غيـر

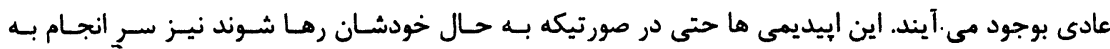
هيبوياميزو انديميك قبلى خود باز ميكردند.

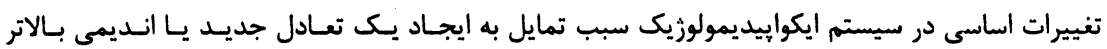

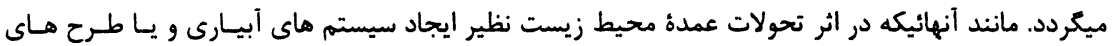

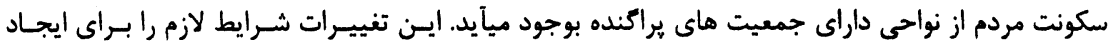

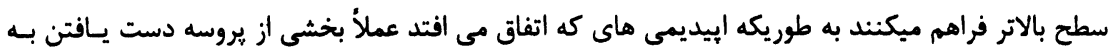

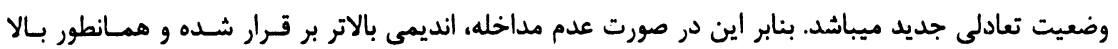

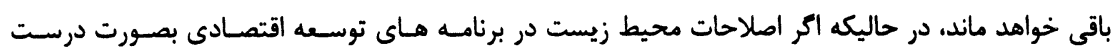

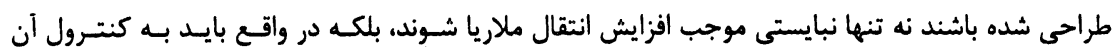

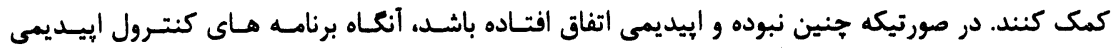

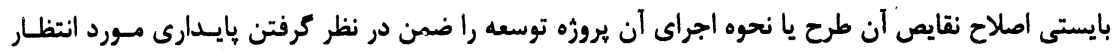

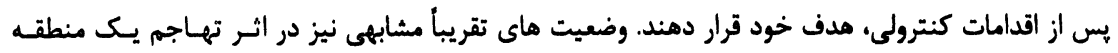

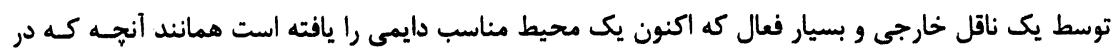

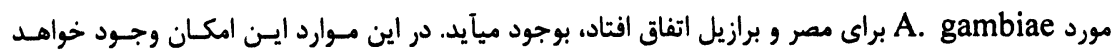

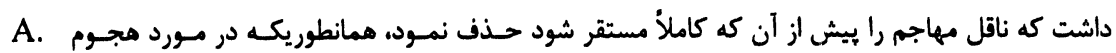
gambiae به مناطق ذكر شده اتفاق افتاد.

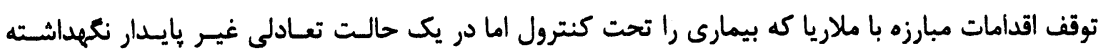

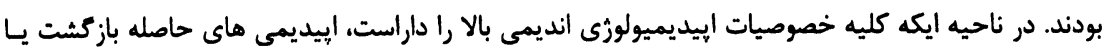

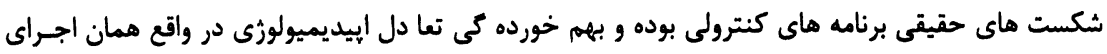

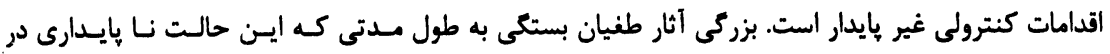

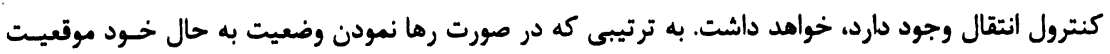

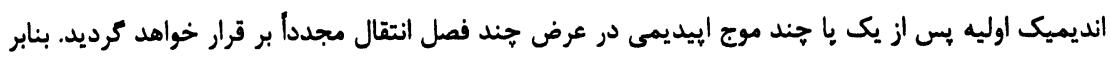

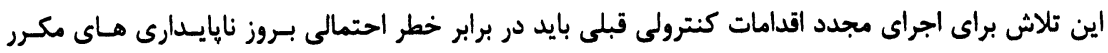

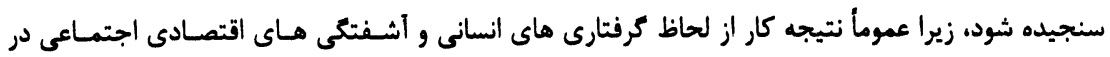

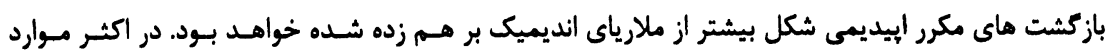

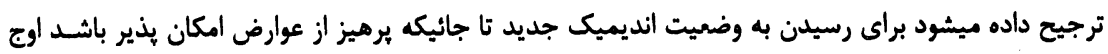

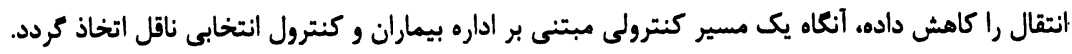

\section{r. موج ها و تناوب إييديمى (Epidemic Waves and Periodicity):}

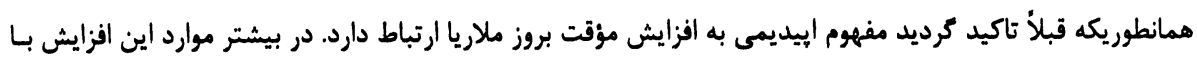

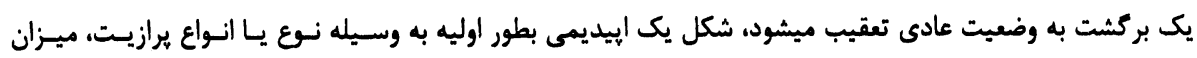
تلقيح آن و نسبت افراد مستعد در جمعيت انسانى تعين ميكردد. 


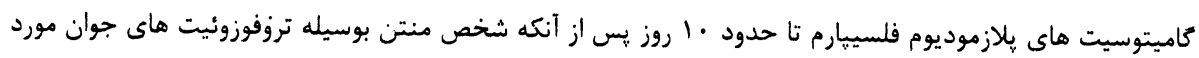

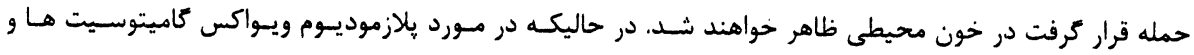

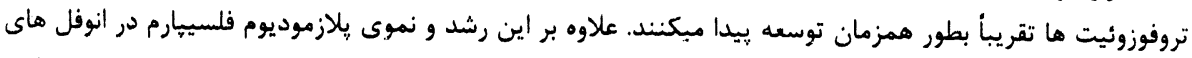

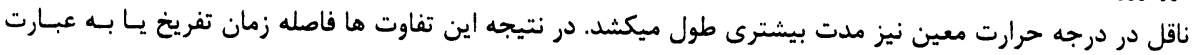

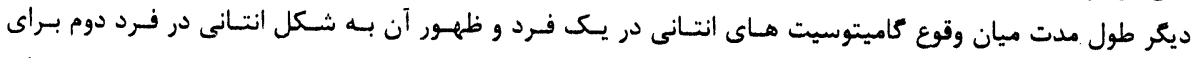

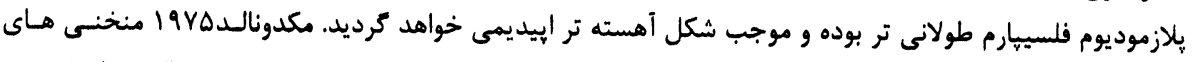

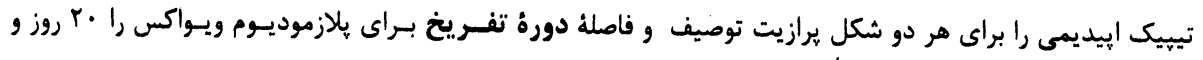

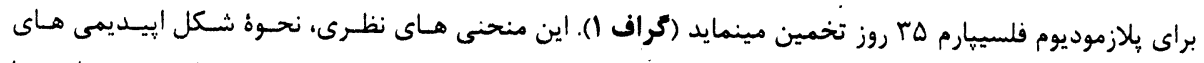

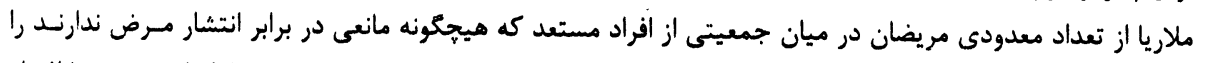

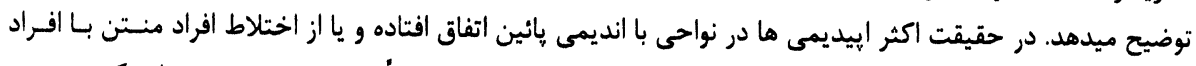

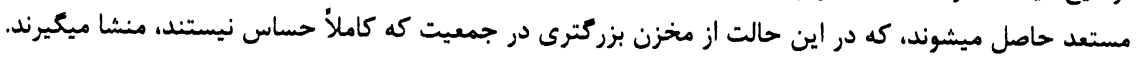

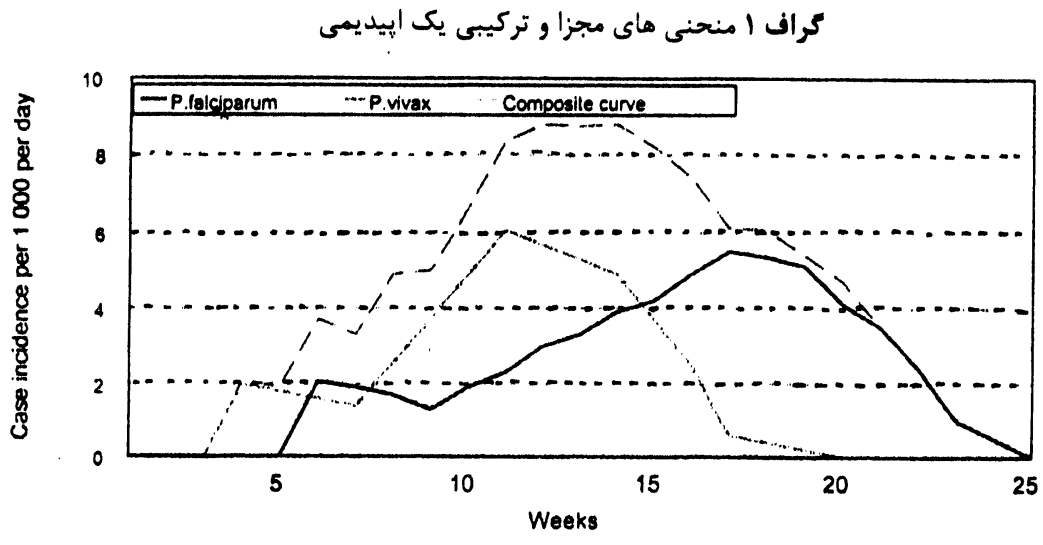

(مك دونالد أبلا اجازه نشر از دانشكاه اكسفورد)

اييديمى هاى يلازموديوم وايواكس عمدتأ در نواحى داراى انتقال فصلى اتفاق افتاده و در واقع بزركنمائى هـاى از اوج

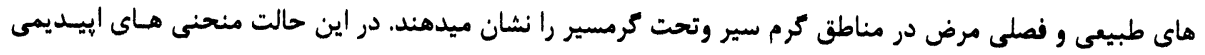

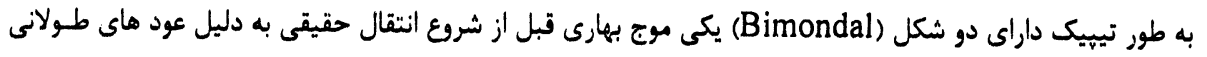

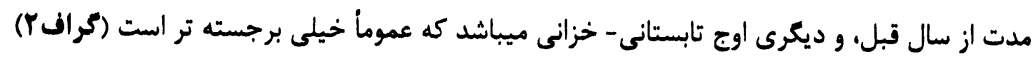

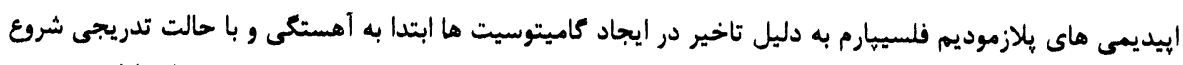

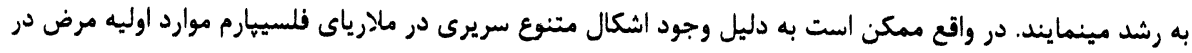

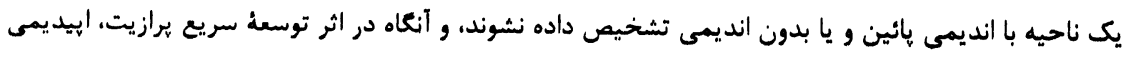
بصورت كاملأ انفجارى ظاهر كردد. 


\section{WHO/MAL/98.1084}

صفو

$$
\text { كراف Y ابتلا ماهانه ملاريا - يوسادا - ساردينا • }
$$

Graph 2 Monthly malaria morbidity, Posada, Sardinia, 1930

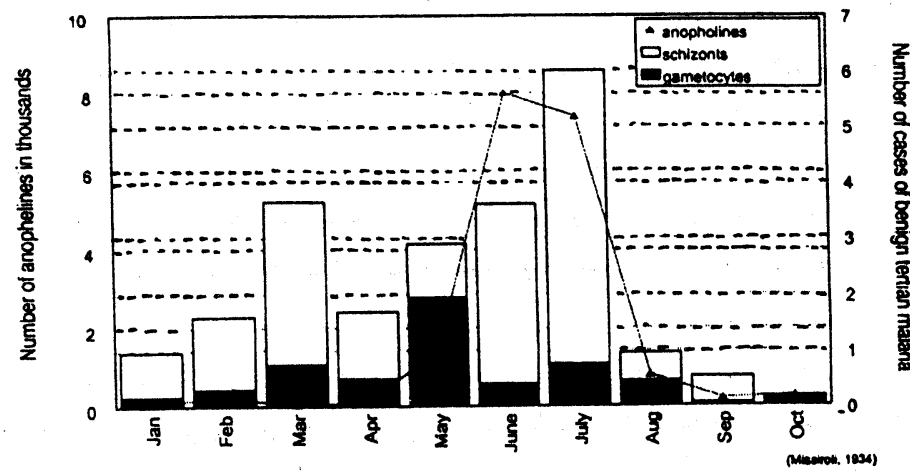

إيديمى هاي يلازموديوم ملاريا بسيار نادر هستند. اين نوع إيبديمى ها ممكن است در جوامع جدا شـده اتفـاق افتـد.

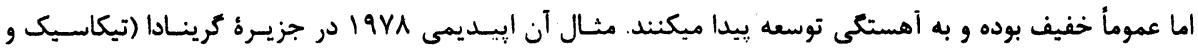

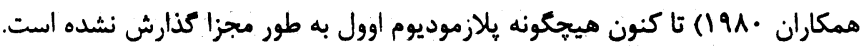

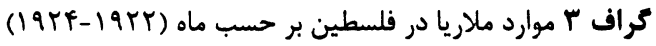

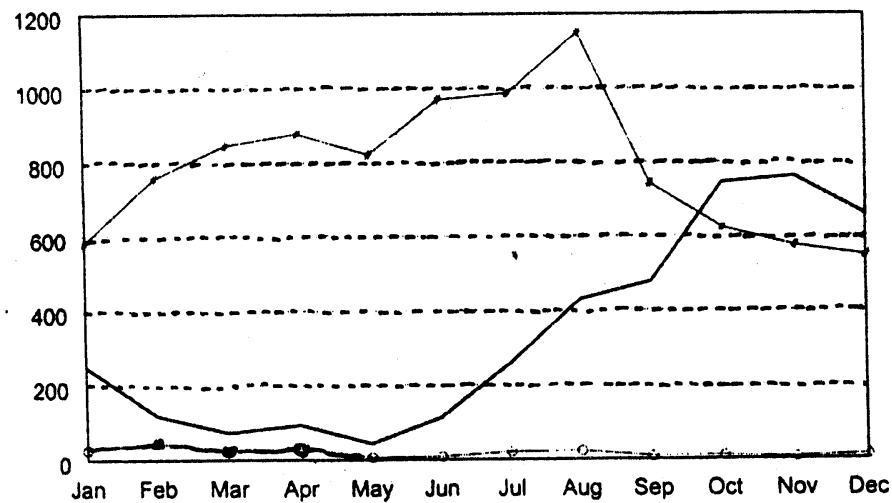

-P.vivax -P.falciparum op.malariae

(Kligler, 1930)

به استثناى افريقاى كر مسير، معمـولاً اكثريست اليـديمى هـا توسـط يـك نـوع واحـد ايجــاد نميشـود بلكـهـ بصـورت

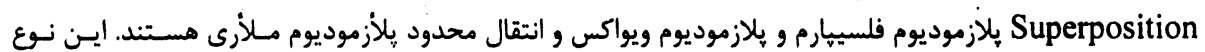

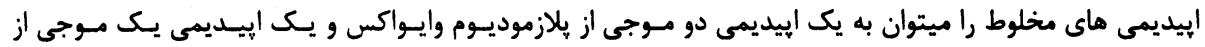

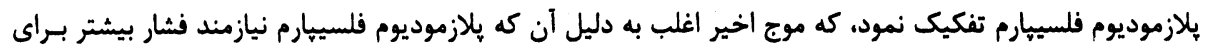

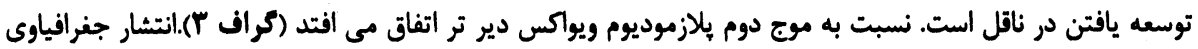

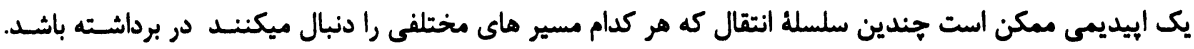




\section{WHO/MAL/98.1084}

صفحه

به طوريكه ممكن است data هاى تجمعى براى يك ناحية نسبتاً بزرى يك إيديمى نسبتأ طولانى را نشان بدهند اما

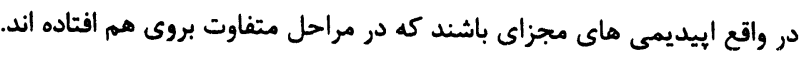

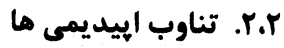

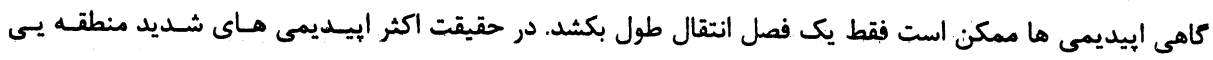

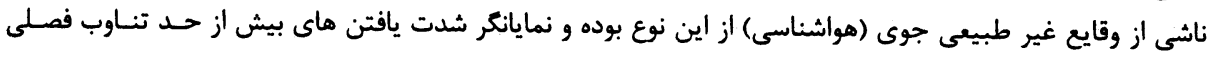

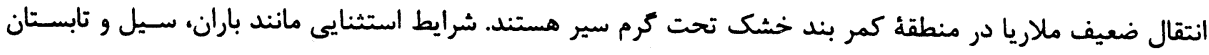

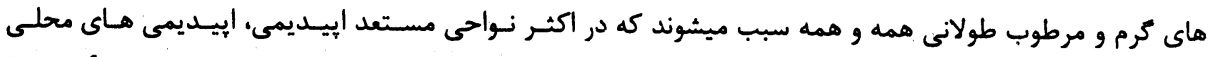

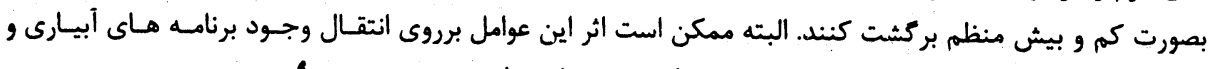
كشاورزى و بخصوص براكندكى جمعيت و معافيت كروهى متفاوت باشد.

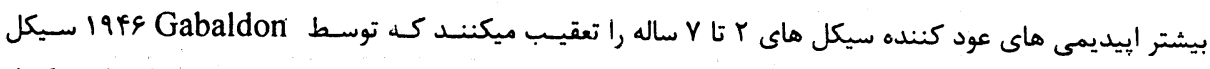

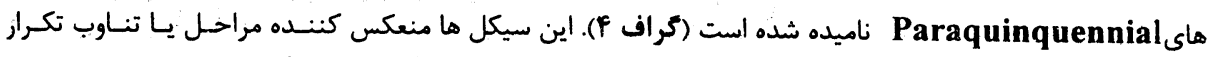

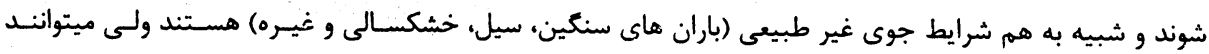

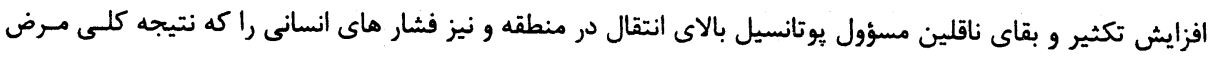
را تشديد ميكنند تعين نمايند.

بعضى نواحى در هر سيكل هوا شناسى Paraquinquennial تحت تاثير اييديمى ها قرار ميكرند، در حاليكه نـواحى ديكر ممكن است فقط در شرايط غير طبيعى شديد تر تحت تاثير قرار كرفته و سيكل هاى تناوبى يا مرحلوى نزديك به ده سال يا بيشتر را تعقيب نمايند.

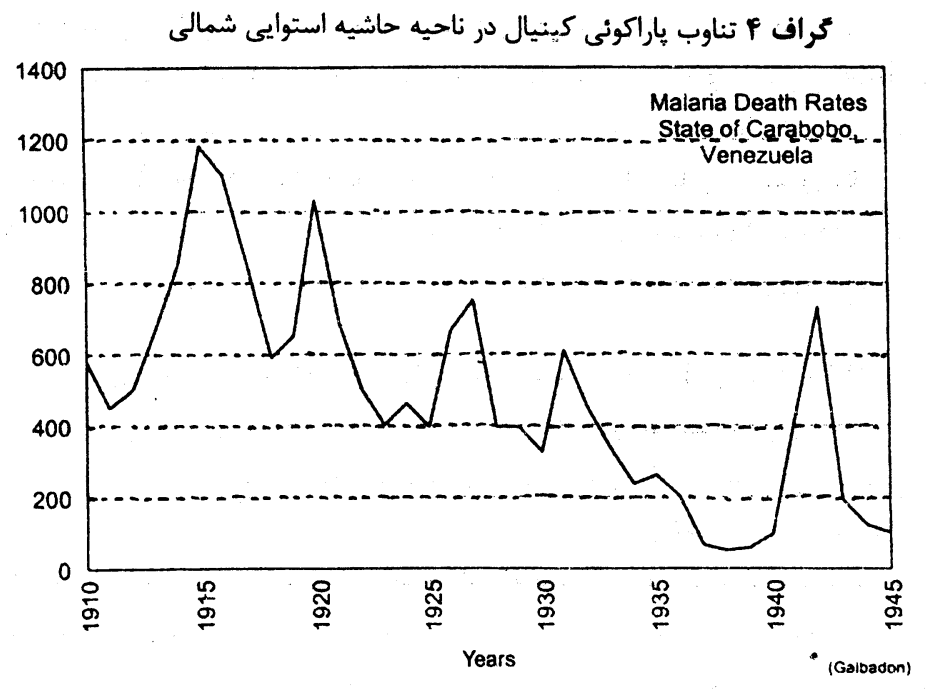

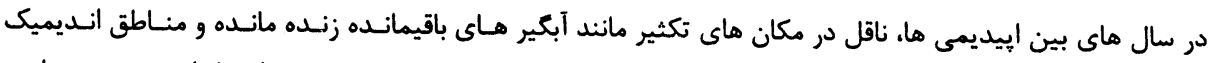

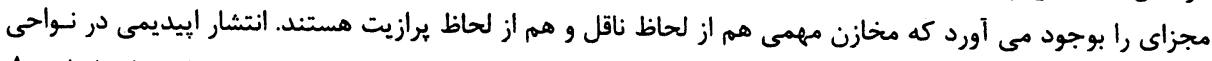

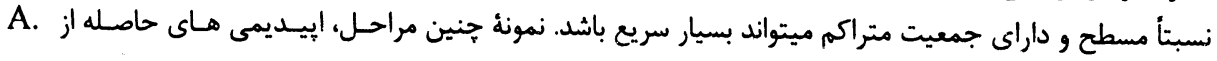




\section{WHO/MAL/98.1084}

صفح 1

albimonus در لانوس كشور وينزويلا (شكل ه الف) . ... ـ كه عمدتأ به خاطر ازدياد انوفيل ها به دنبال بارنـدكى

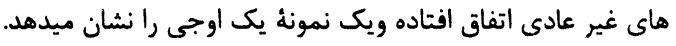

كراف ه ب ميزان مرك در إيديمى

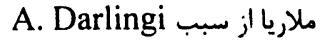

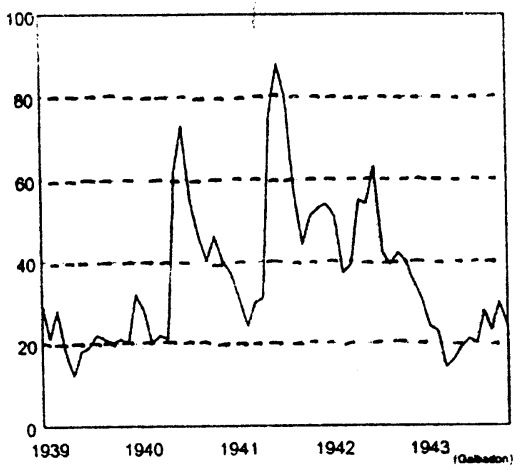

كراف ها الف ميزان مرى در

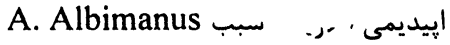

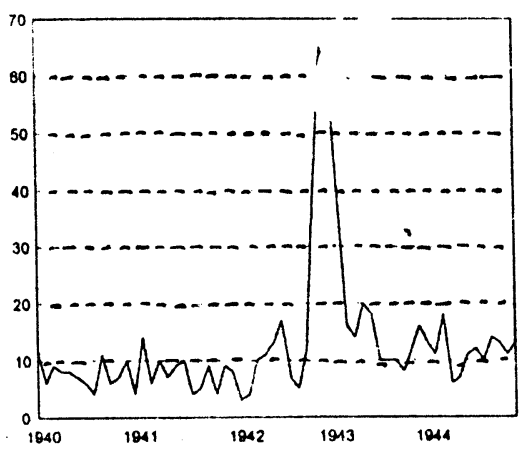

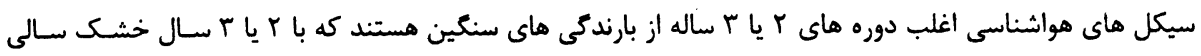

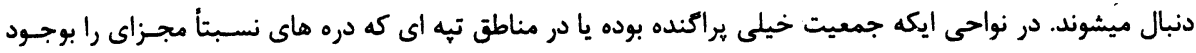

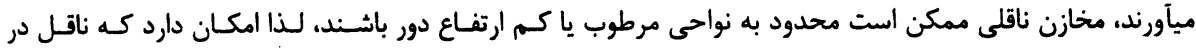

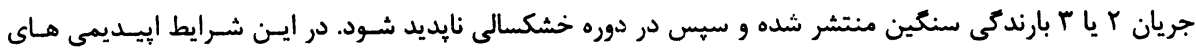

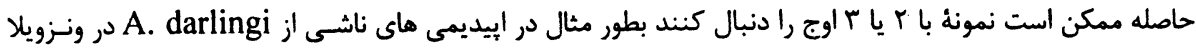

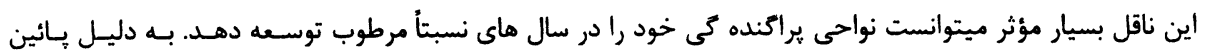

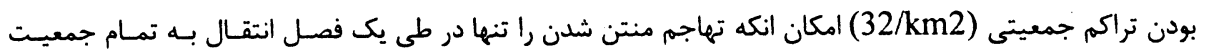

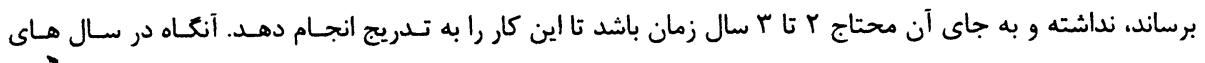

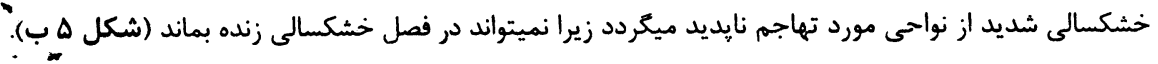
مثال هاى كه تا كنون نشان هاده شده اند (كرافهاى ا تا ه) همه به دورة قبل از شروع عمليات محو ملاريا در كشـور

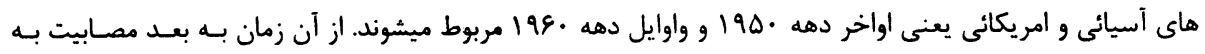

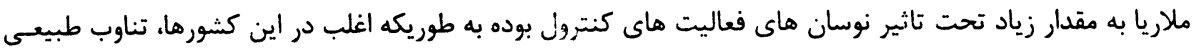

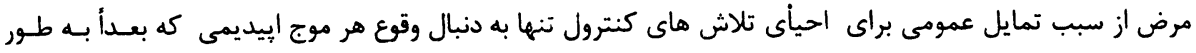

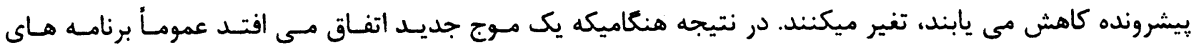

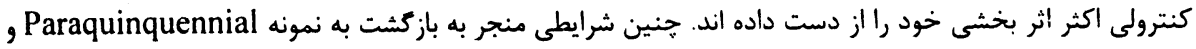

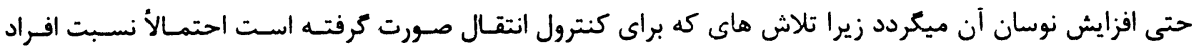




\section{WHO/MAL/98.1084}

صفحس

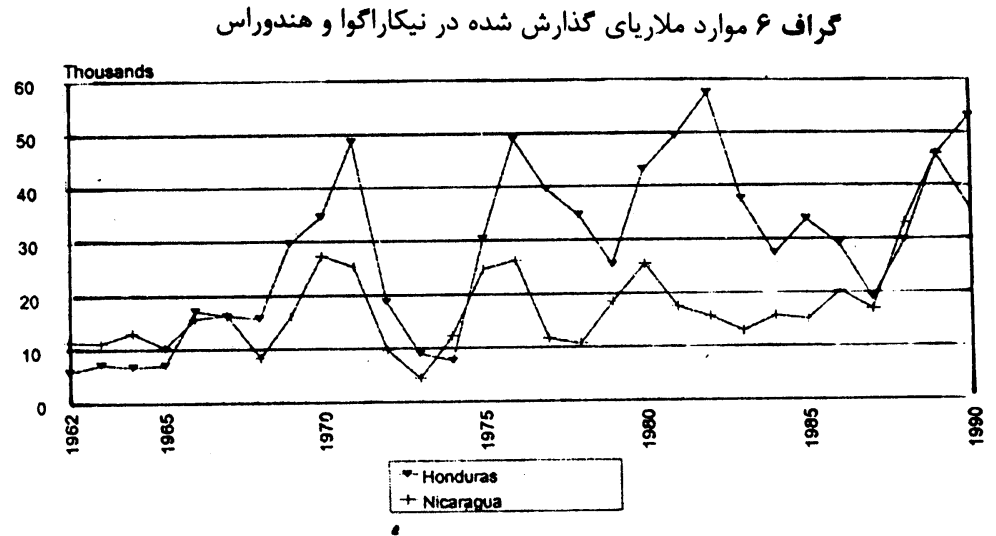

كراف V موارد ملارياى كذارش شده در ايران

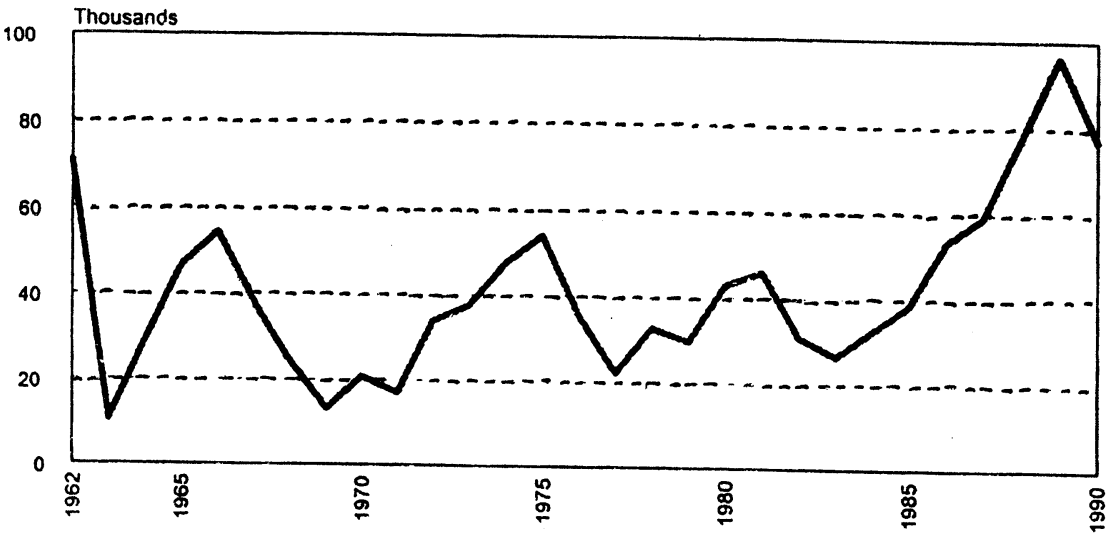

r. طبقه بندى انواع اصلى الييديمى هاى ملاريا (Classification of Major Epidemic Types)

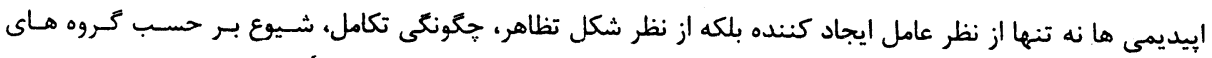

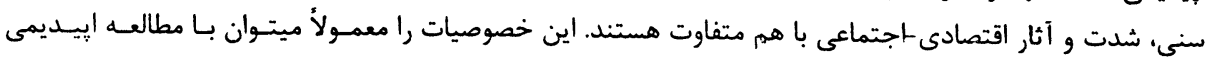

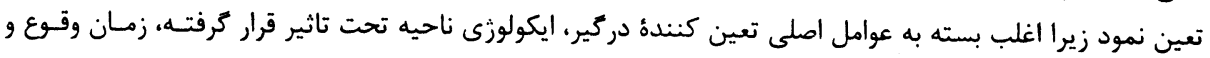

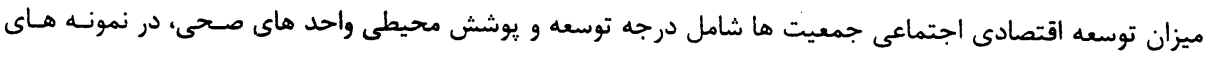

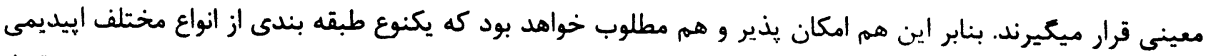

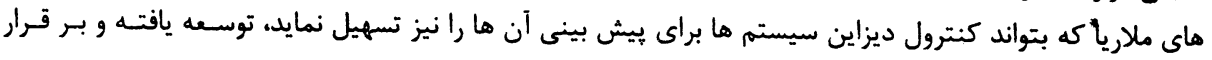




\section{WHO/MAL/98.1084}

1. صفحس

بسيارى از تغييراتيكه ساختار مغلق يك إيديمى را تشكيل ميدهند بطـور كامـل مسنتقل از يكسديكر نبـوده و عمومـاً

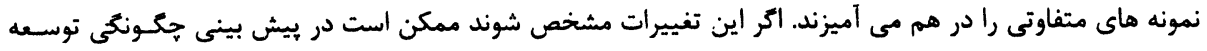

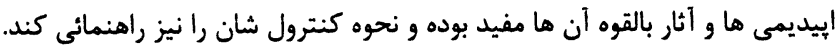

يكنوع طبقه بندى مقدماتى از انواع مختلف إيديمى هاى ملاريا ميتواند بر اساس تظاهز ابتــايى تكامـل اوليـه و هـم

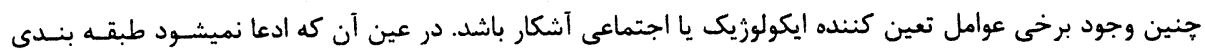

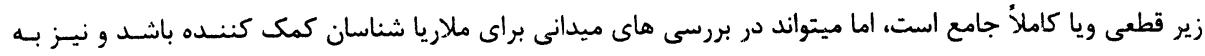

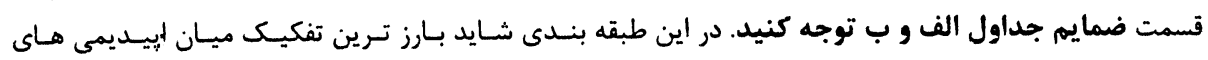

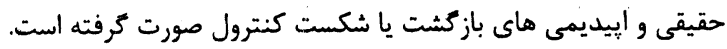

\section{دابـ إييديمى هاى حقيقى}

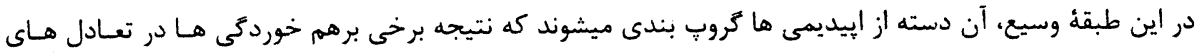

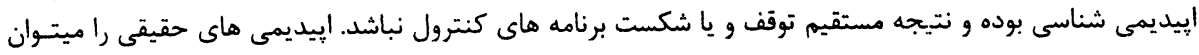

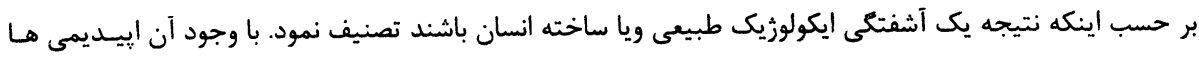

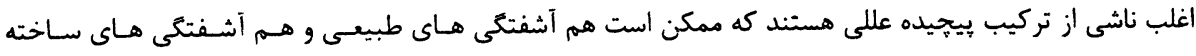

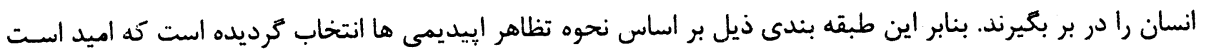

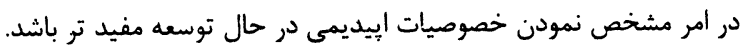

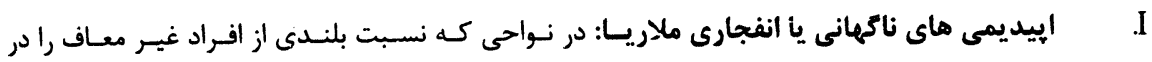

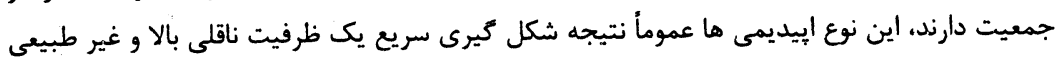

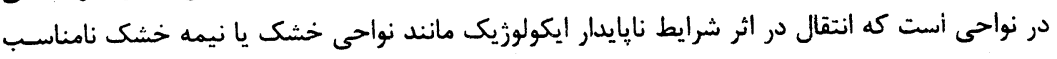

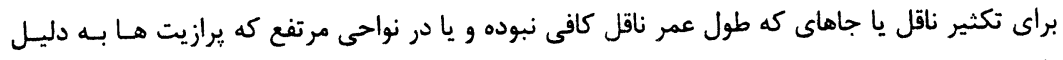

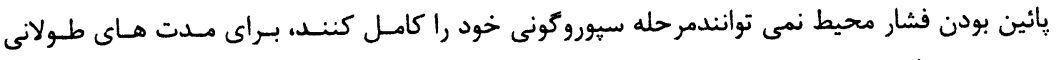

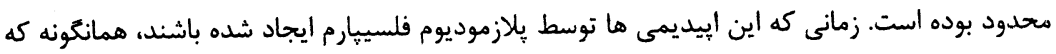

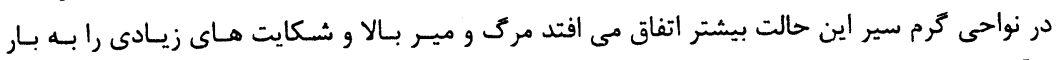

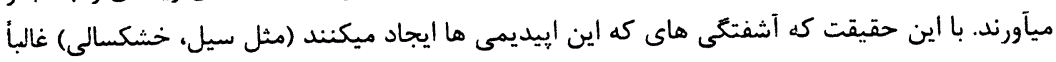

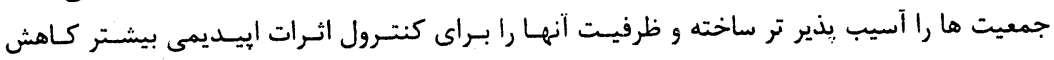

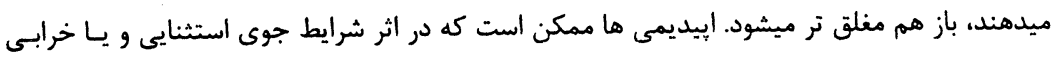

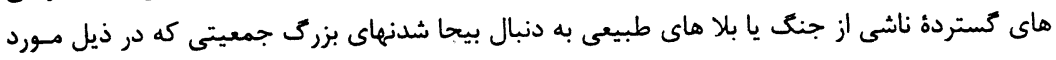

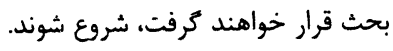

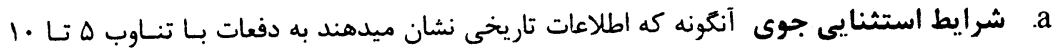

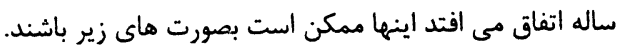

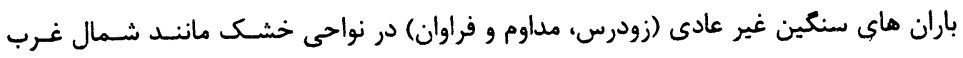

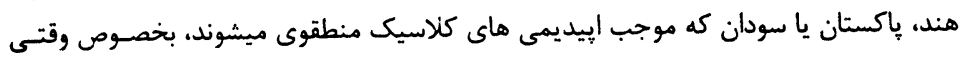




\section{WHO/MAL/98.1084}

\section{صفحس 11}

كه به تعقيب يك سال خشك غير عادى اتفاق افتاده و يك جمعيت ضعيف شده را تحت تساثير

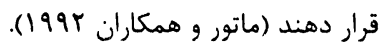
سيل هاى وسيع رود خانه هاى وسيعى مثل نيل در شمال مركزي (ماتور و سودان يا نيجير يا، سنيكال،

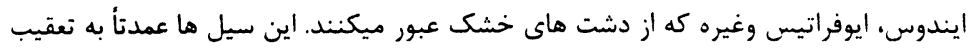

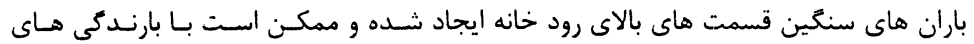

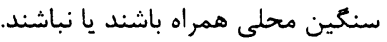

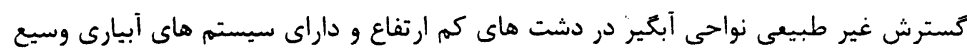

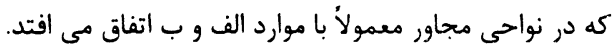

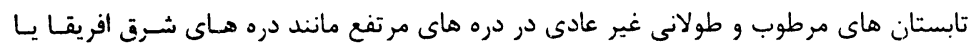

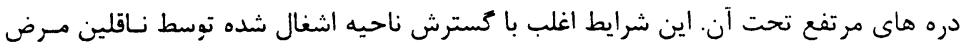

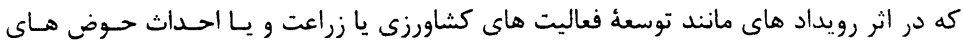

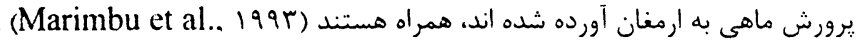

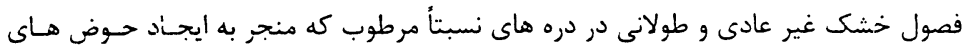

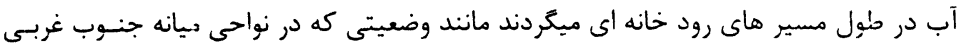

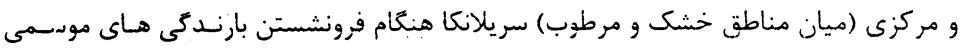

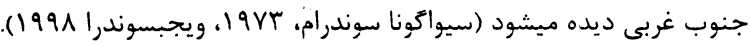

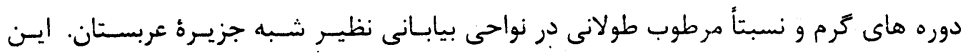

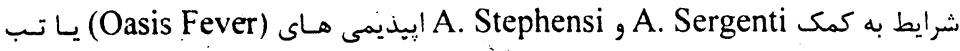
واحه را بوجود مى. آورند كه در كذشته سرتاسر مجمع هاى مسكوني جذيسد را فرا كرفتسه و در

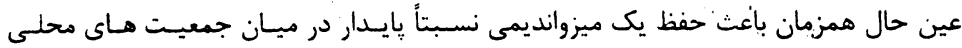

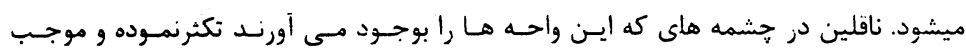

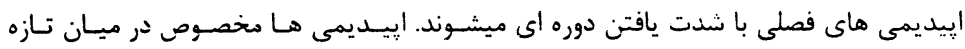

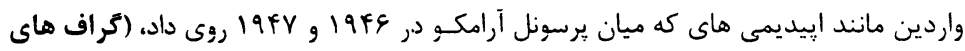

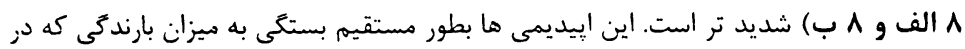

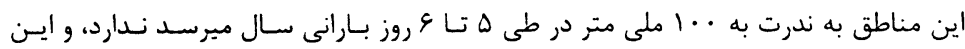

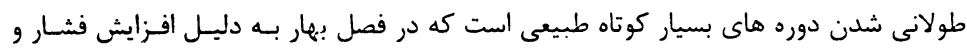

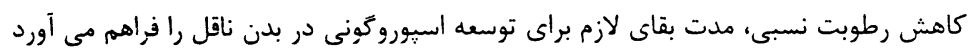

همه اى اين إيديمى ها به شكل د.وره هاى نيمه منظم اتفاق مى افتد و بنابر اين در صورت فراهم بودن

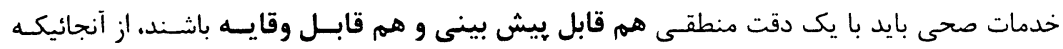

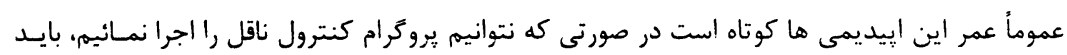

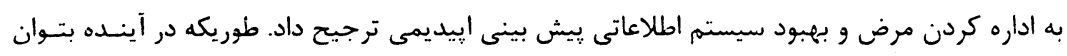
با كنترول به موقع ناقل، از إيديدى هاى ذئ ذيل وقايه نمود. 
WHO/MAL/98.1084

\section{صفحس}

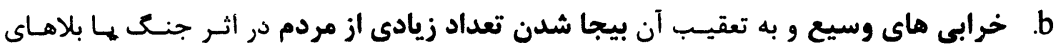

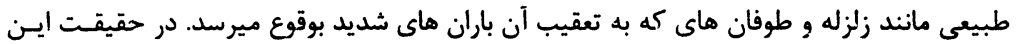

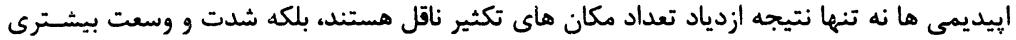

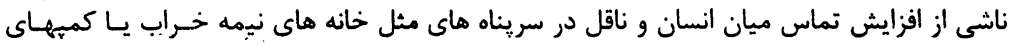

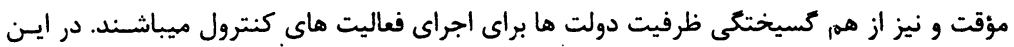

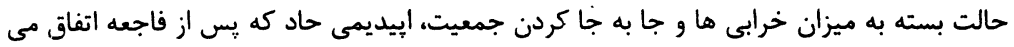

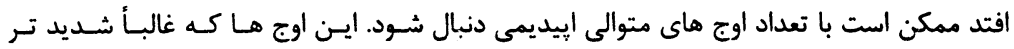

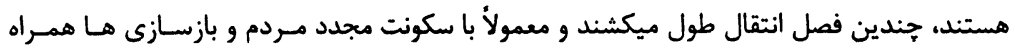
مى باشند.

كراف ^ الف وقوع فصلى ملاريا در ارتباط با فشار و رطوبت در واحه قطيف $19 f \&$

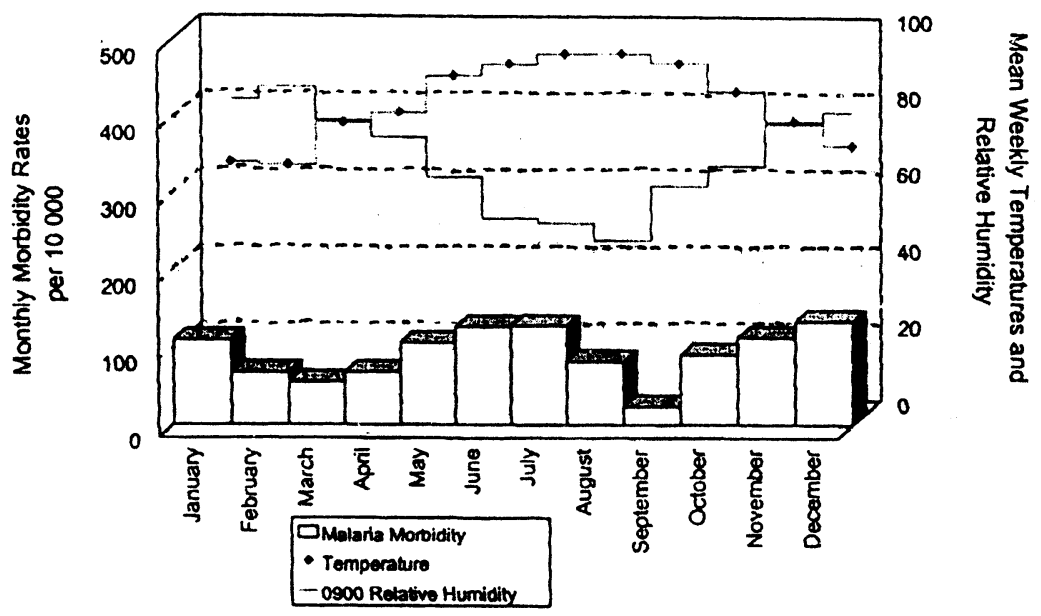


WHO/MAL/98.1084

صفح ri

كراف ^ ب وقوع فصلى ملاريا در ارتباط با فشار و رطوبت در واحه قطيف I9fv

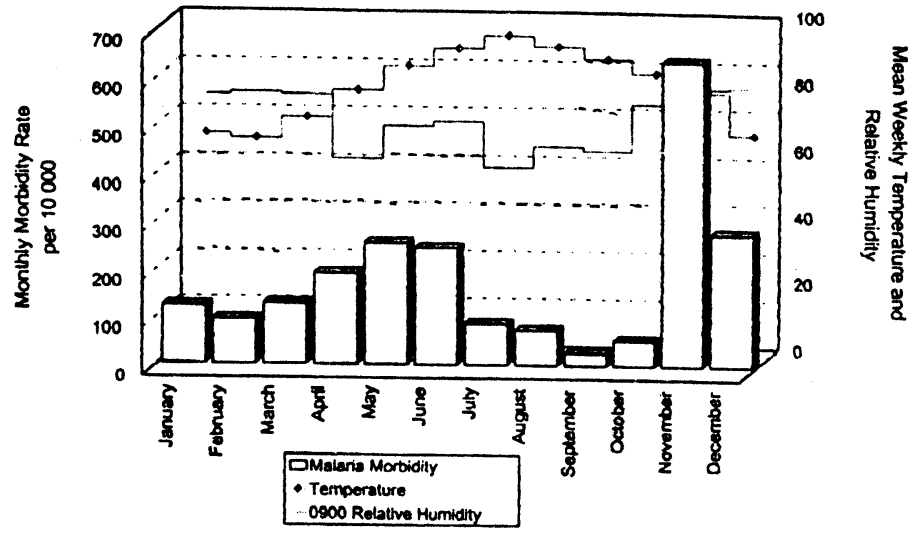

(Daggy, The Americen Joumal for Tropical Medicine and Hygiene, 1959)

كراف 9 مصابيت و مرك و مير ثبت شدة ناشى از ملاريا در ايتاليا

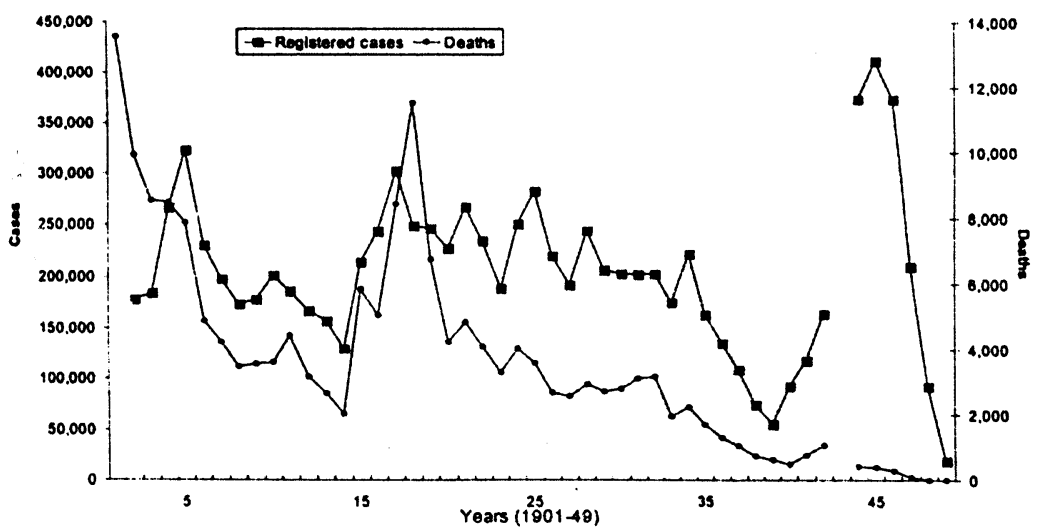

بزرتى خرابى ها و بايدارى وضعيت قبلى كاهى ممكن است طورى باشند كه:

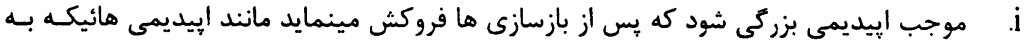

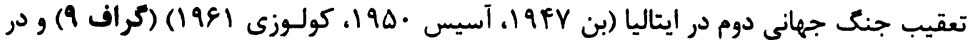

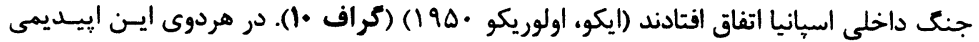

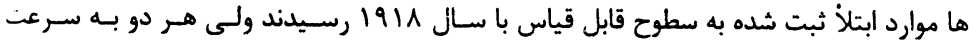

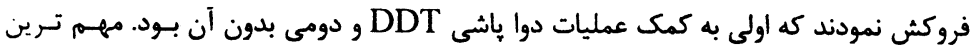


WHO/MAL/98.1084

صفحه \&

اختلاف ميان آنها اين بود كه در حاليكن، إيديمى اسيانيا منجربه مرك و ميسر زيـاد كرديـد، در

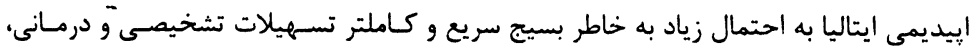
مرك و مير بلند اتفاق نيفتاد.

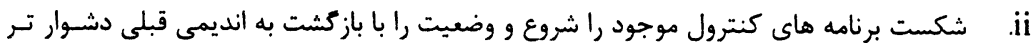

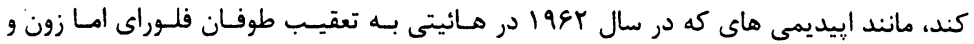

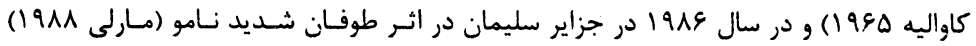
اتفاق افتادند. موجب يك تحول بزرى اجتماعى اقتصادى شود. طوريكه ميل به سـوى برقـرارى يـك تعـادل

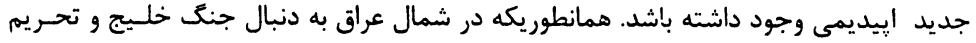

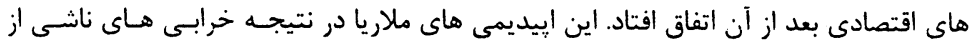

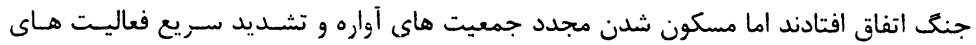

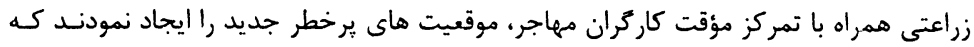

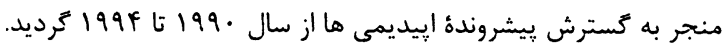

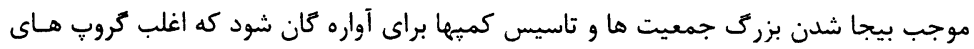
iv

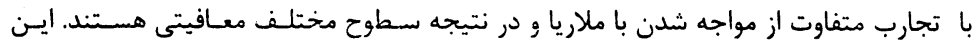

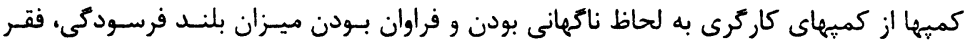

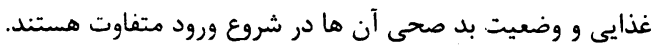

\section{كراف •ا موارد ملاريا و مرك و مير ثبت شده از آن در اسيانيا}

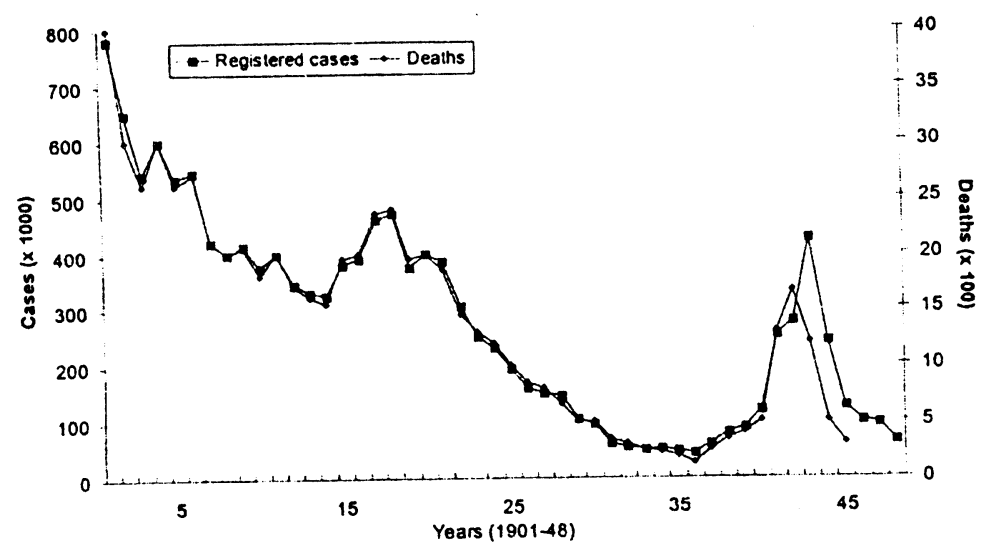

با اينكه اينكونه إِيديمى ها عموماً حالت دوره يى ندارند، اما به تعقيب يك فاجعه قابـل بــيش بينسى

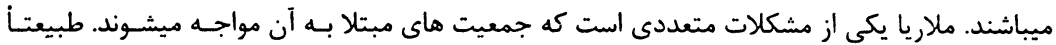

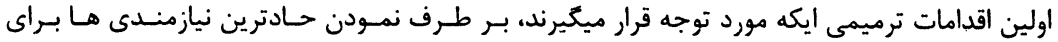

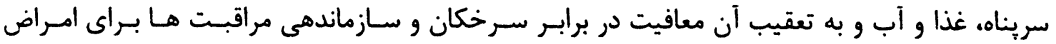




\section{WHO/MAL/98.1084}

10 صفحه

اسهالى، انتانات حاد تنفسى و ملاريا ميباشد. در صورتيكه امكان يـذير باشـد، اقـدامات كنترولى ملاريـا

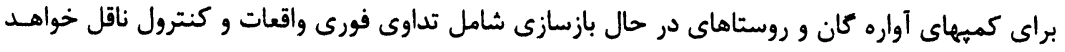

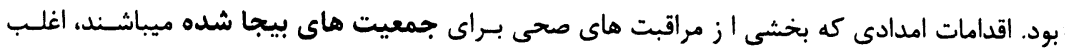

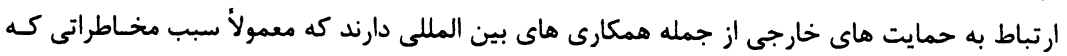

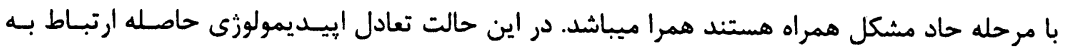

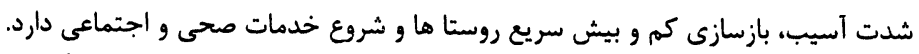

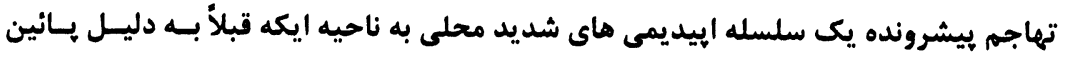

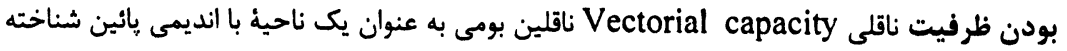

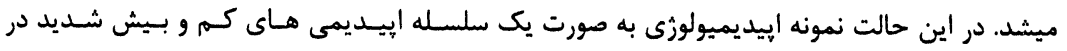

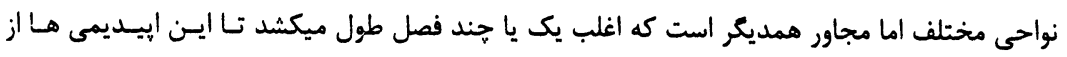

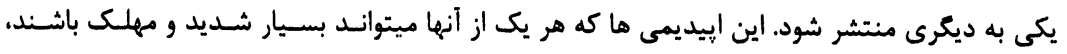

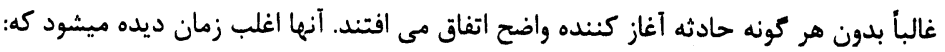

الف:يك ناقل خارجى يا قبلأ حذف شده، ناحيه ايى راكه در حال حاضر اقامت بسيار مناسبى بـراى

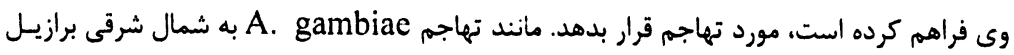

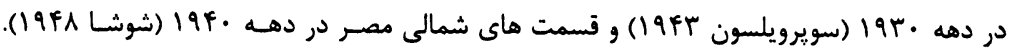
ب: يك ناقل خطر ناك هنكامى كه مؤقتأ شرايط مناسب براى بقا و تكثير وى در نواحى مجـاور حاصل

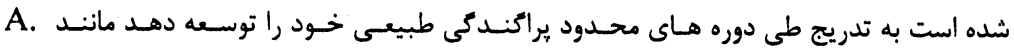
كarlingi

ج: يك ناحيه بوسيله ناقلى كه قبلأ حذف شده بوده است مجددأ مورد تهاجم قرار بكيرد مانند منساطق

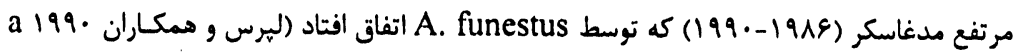

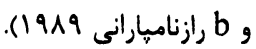

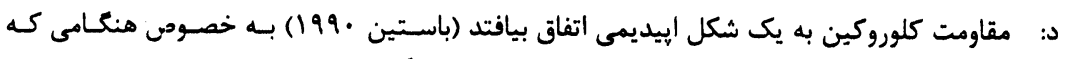

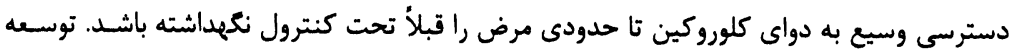

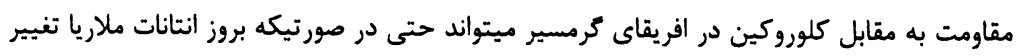
نكند، به عنوان يك إيديمى نيز تلقى شود (وارسام و همكاران ه99 199 ).

هر جند كه اساساً جنين إيديمى ها غير قابل هيش بينى هستند، اما تا حدى ييثـرفت آنها قابـل يـيش

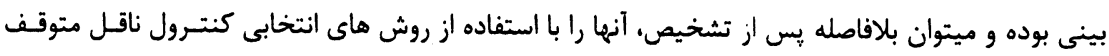

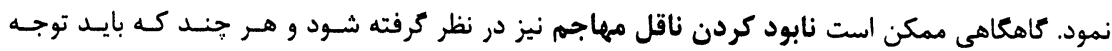

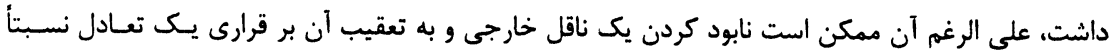

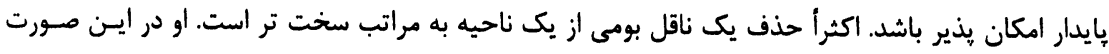

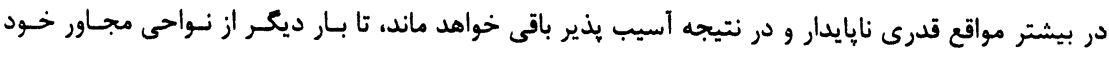




\section{WHO/MAL/98.1084}

17 صفحى

در نواحى شديداً ملاريائى، نمونه هاى اييديميولوزيكى مشابهى به تعقيب اقـدامات عمـومى مثـل ســاخت راه

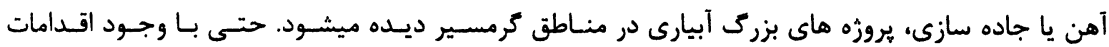

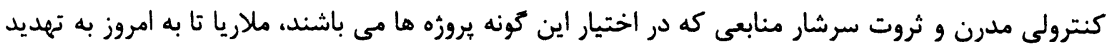

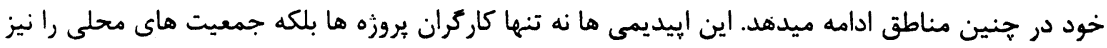

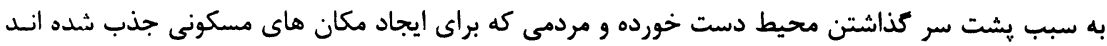

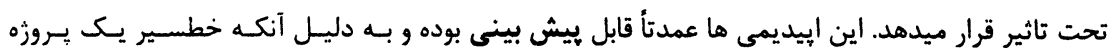

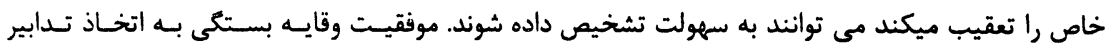

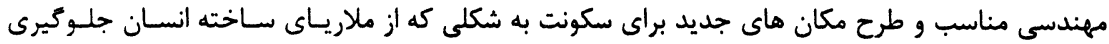

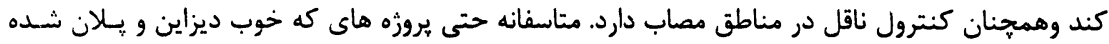

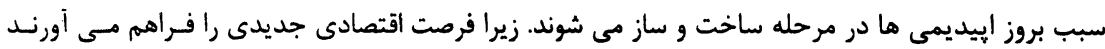

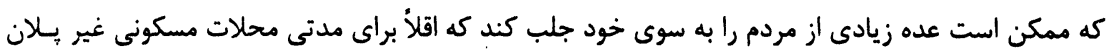

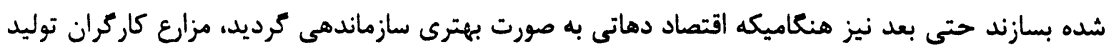

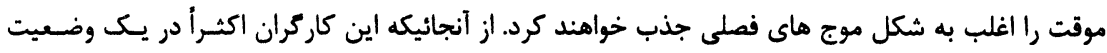

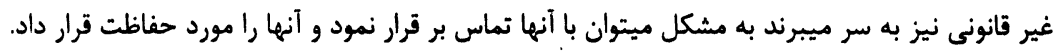

إييديمى هاى محراقى در نواحييكه بايدارى ملاريا به افزايش است، اينها عمومأ بـه تعقيـب يـك

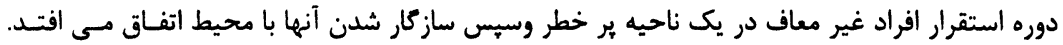

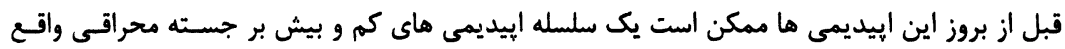

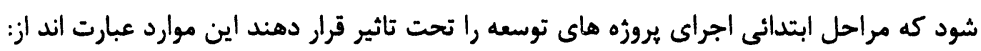

الف: ساكنين نواحى جنكلى كرمسيرى كه توسط جمعيت هاى كه بطور اوليه حساس بوده و براى حفظ

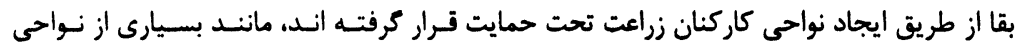

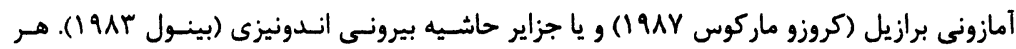

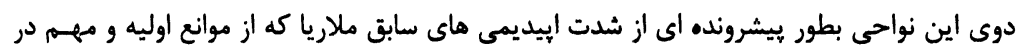

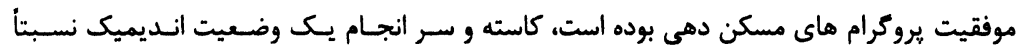

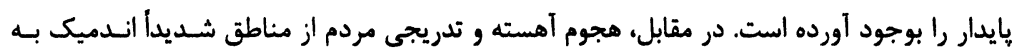

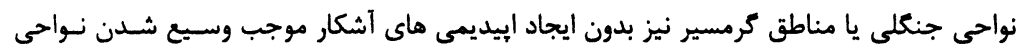

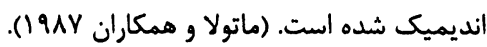

ب: رشد انفجارى مناطق شهرى در نواحى كرمسير كه ورد مداوم تـازه وارديسن بـه آنجـا سـبب شـكل

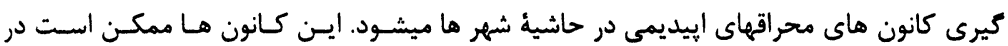

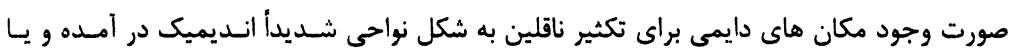

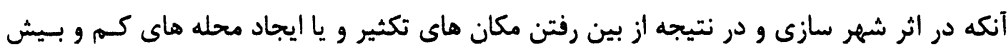

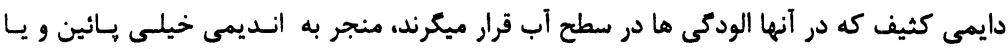

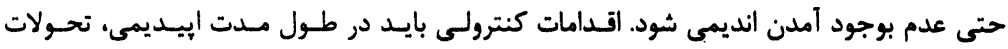

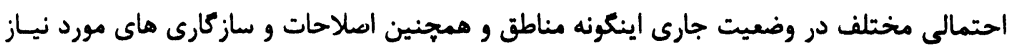


در جهت فراهم نمودن يك ستراتيرى كنترولى مناسب و قابل اجرا براى وضعيت انديميك آينـده را در نظر بكيرند.

ج: استقرار ناقلين مؤثر در مناطق جنكلى در نواحى مجاور دارامى درخت ماند وضسعيتى كـه امـروز در

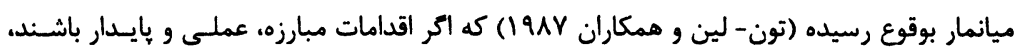

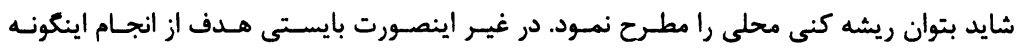

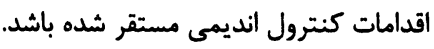

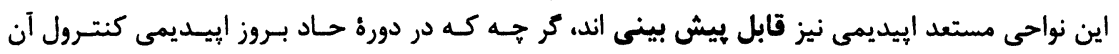

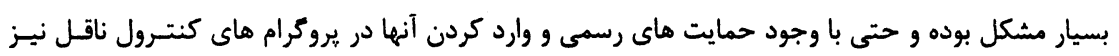

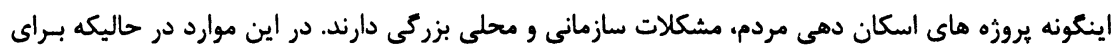

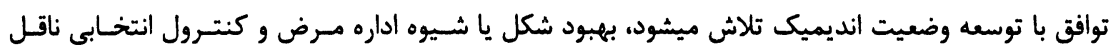

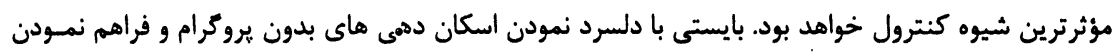

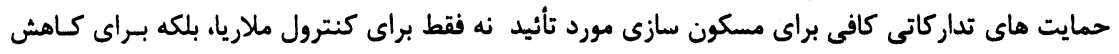

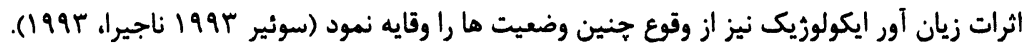

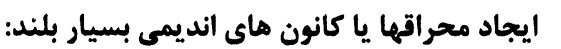

الف: در مناطق معدنى طلا و جواهر در امريكاى جنوبى ويا در جنكل هاى جنوب آسـيا، جريسان مـداوم

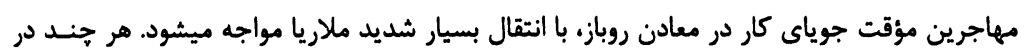

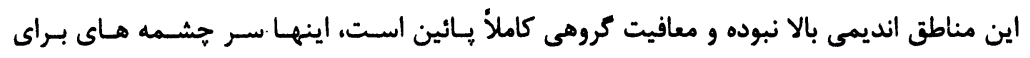

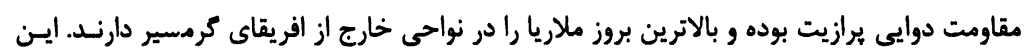

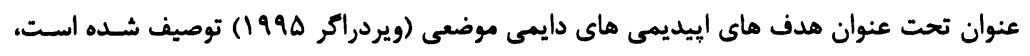

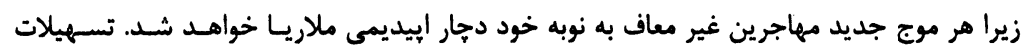

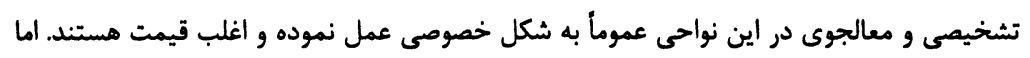

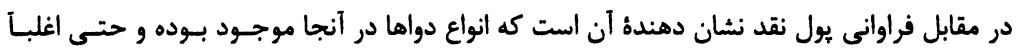

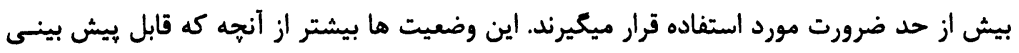

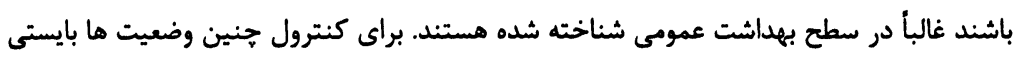

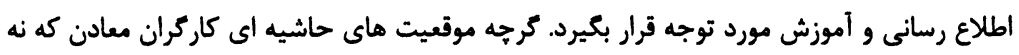

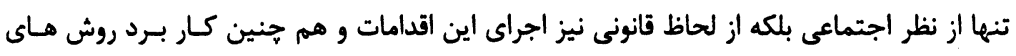

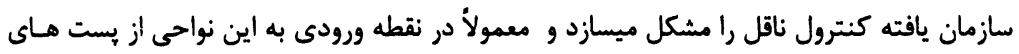

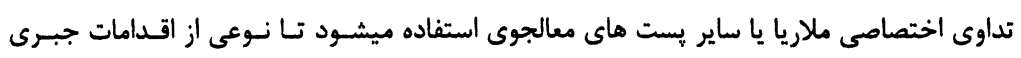

$$
\text { براى كنترول مرض فراهم كردد. }
$$

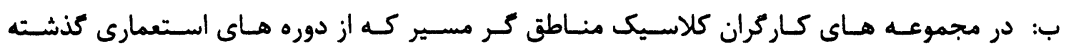

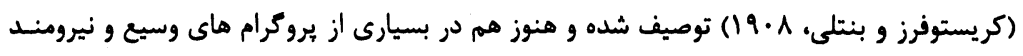

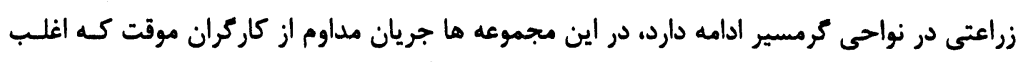

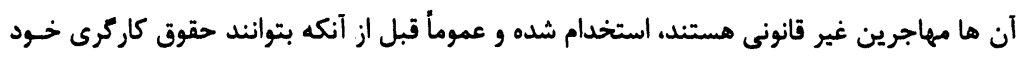

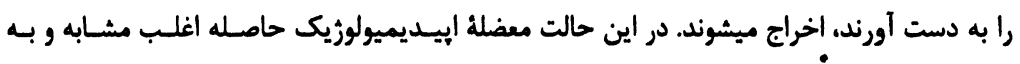


WHO/MAL/98.1084

صفح 11

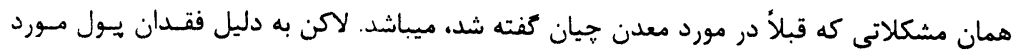

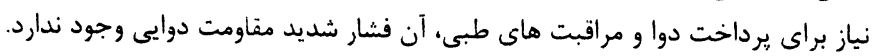

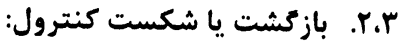

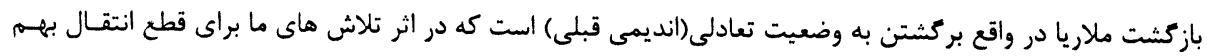

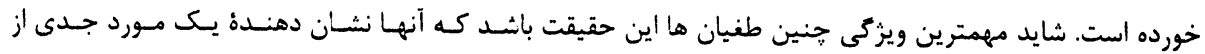

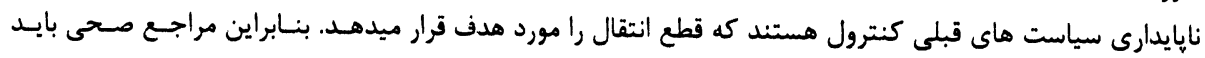

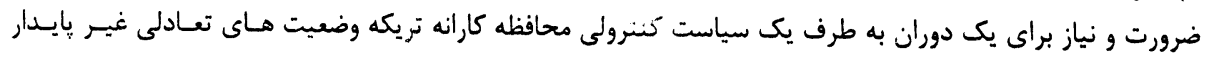

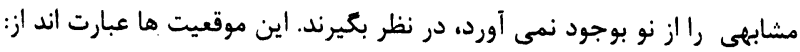

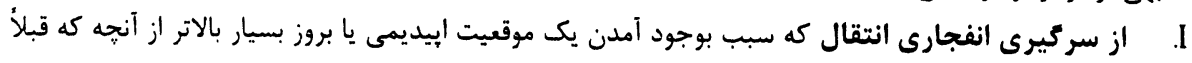

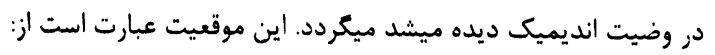

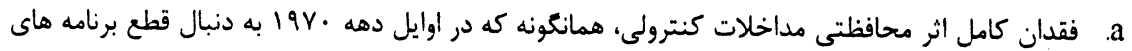

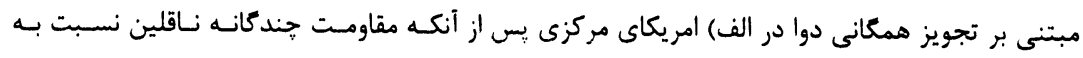

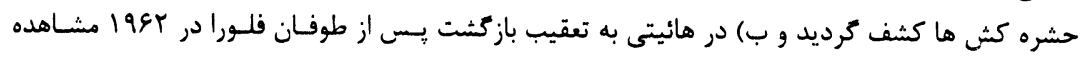

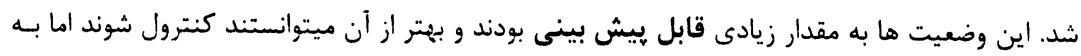

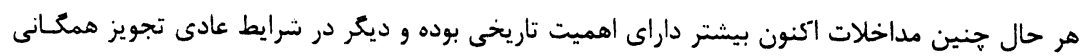
دوا به عنوان اقدامى براى كنترول ملاريا در مقياس وسيع ييشنهاد نميكردد.

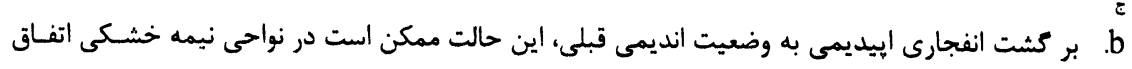

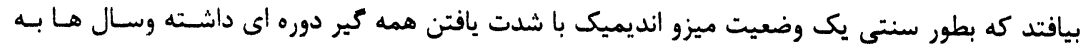

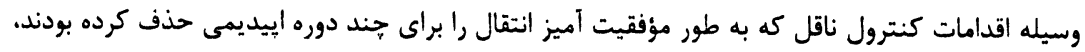

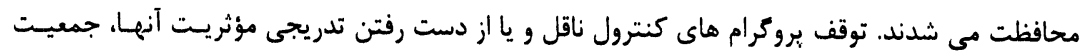

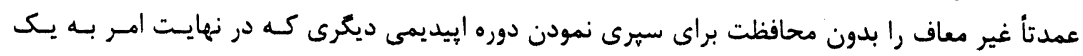

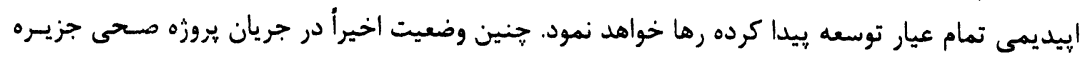

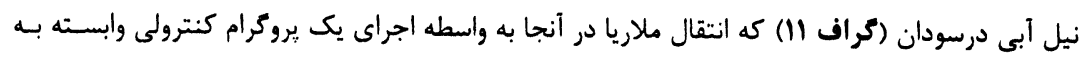

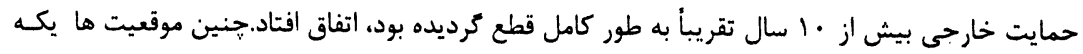

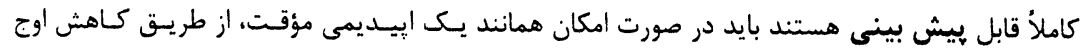

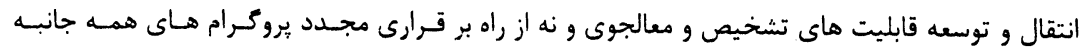

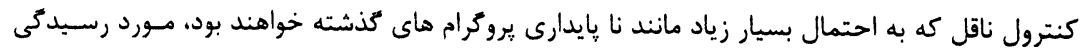
قرار بكيرند. 
WHO/MAL/98.1084

صفحس 19

كراف ال ميزان شيوع ملاريا در الجزيره كودكان r تا و سال

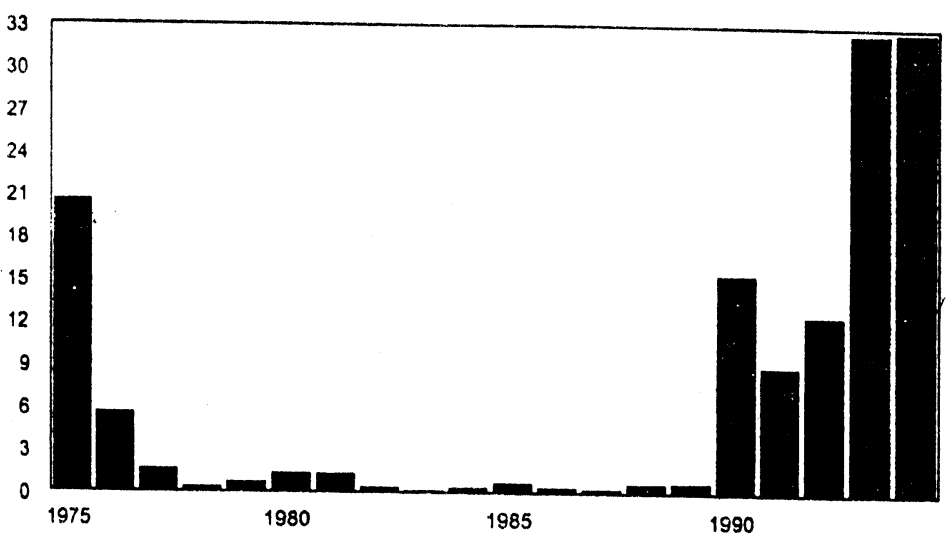

بركشت بيشرونده انديمى به نواحى بسيار انديميكى كه مداخلات قبلى كنترولى انتقـال ملاريـا را در آنجـا

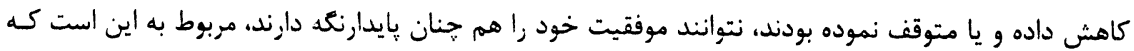

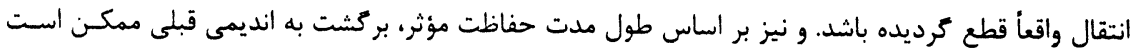

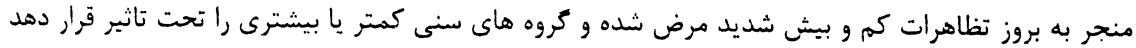

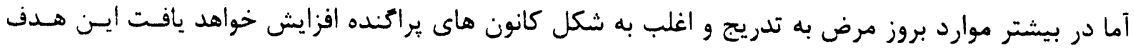

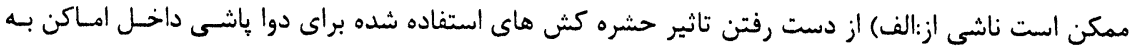

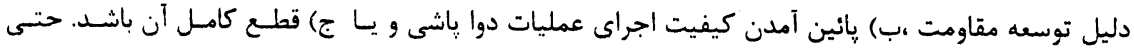

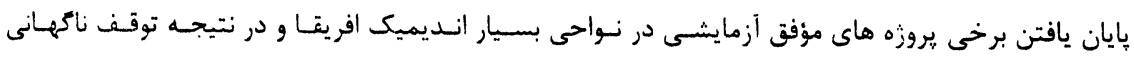

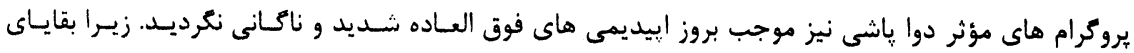

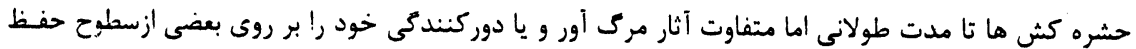

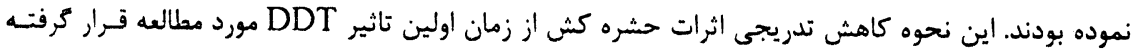

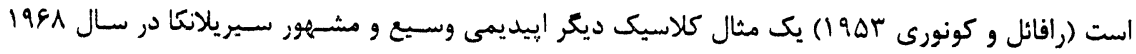

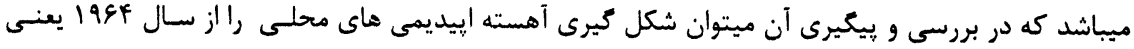

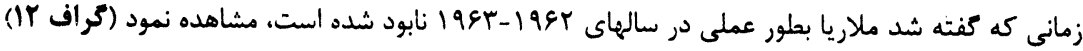

كراف rا موارد ملارياى كذراش شده در سرى لانكا

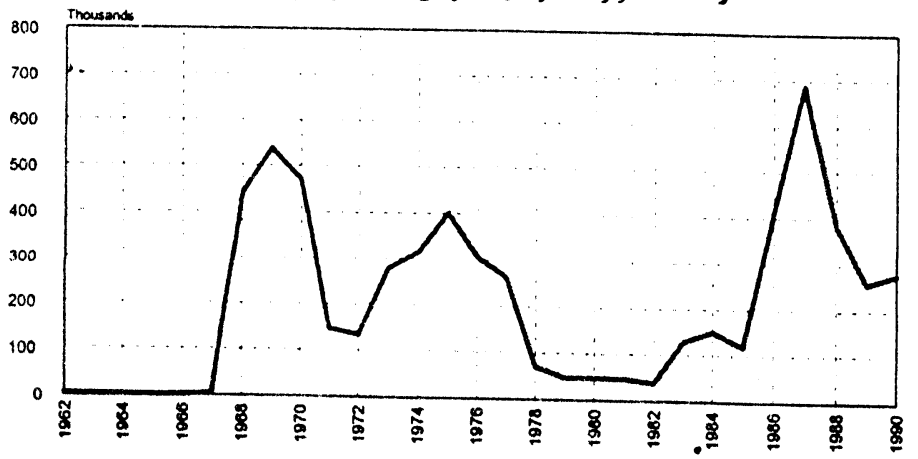


P. Pفحه

بر خلاف نوع قبلى، در نواحى ايكه يتانسيل بلند براى انديمى دارند، انتقال خيلى زود و بـا همـان شـدتى كـه تـاثير

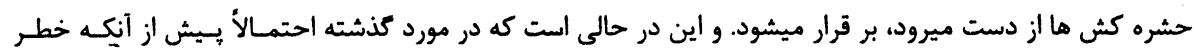

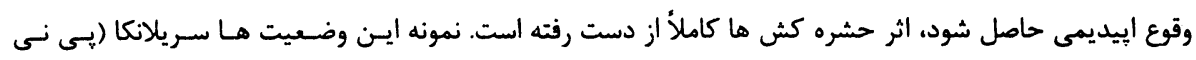

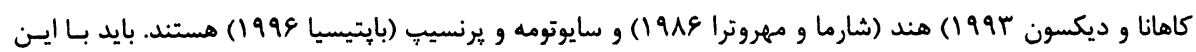

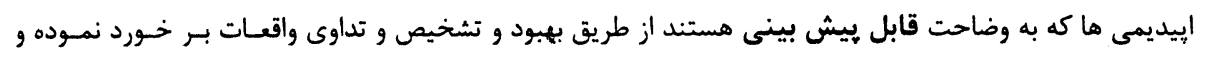

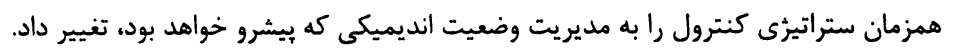

\section{f. تصنيف خطر إييديمى Classification of Epedimic Risk).}

درتنظيم و فورمول بندى Systemic إيديمى به مشخص نمودن نواحى مستعد بر مبناى مطالعه إيديمى هاى اخير

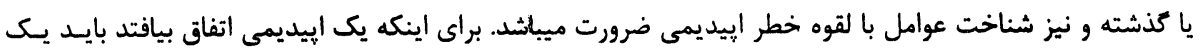

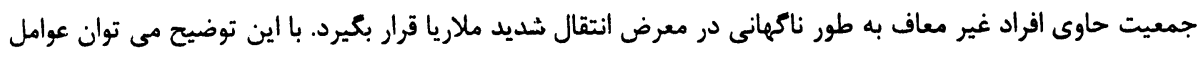

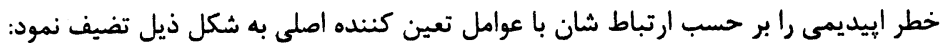

الف: افزايش ناكمانى تعداد افراد غير معاف كه معرض عامل مرض قرار كرفته اند به دليل:

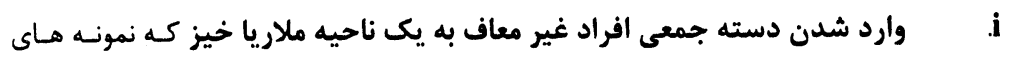

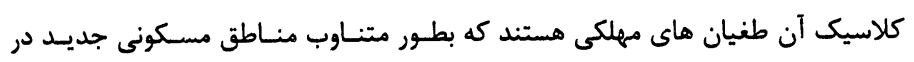

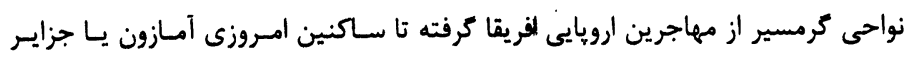

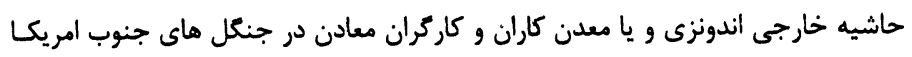

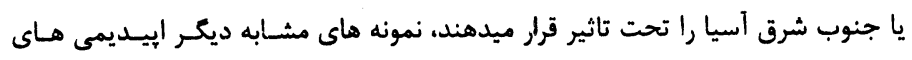

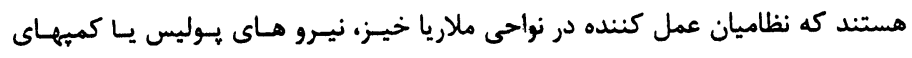

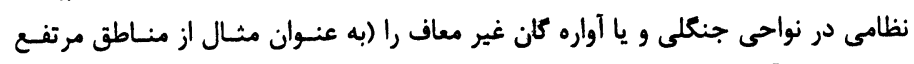

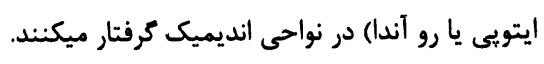

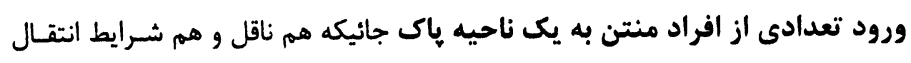
ii

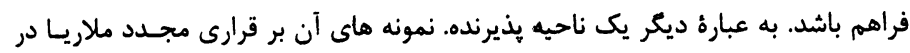

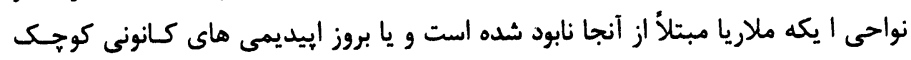

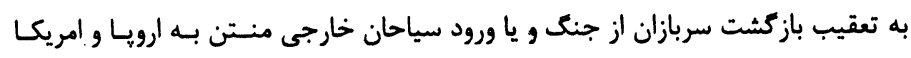

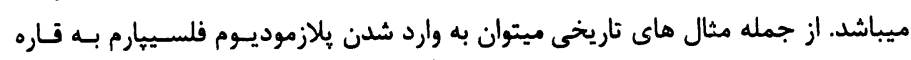

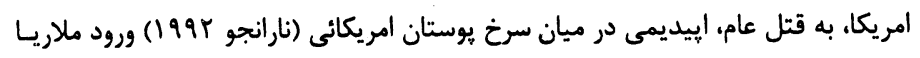

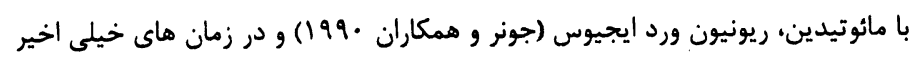

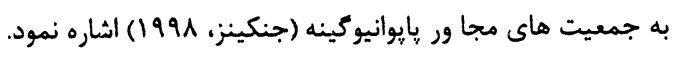

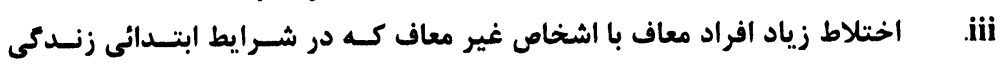

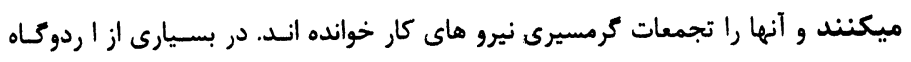

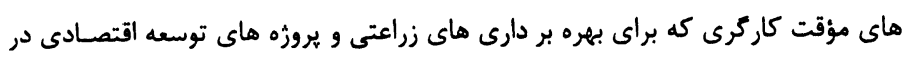

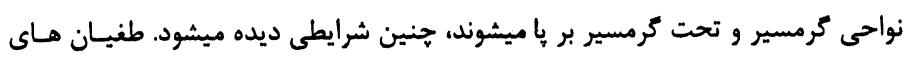


صفحه II

إيديمى اخير كه با توسعة كاشتن درختان كيله و نخـل افريقـايى در برخسى از نـواحى إسى

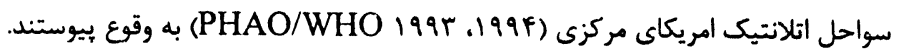

ب: افزايش ناكهانى در ظرفيت ناقل:

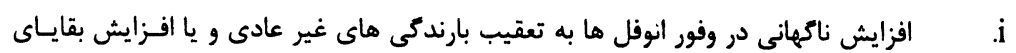

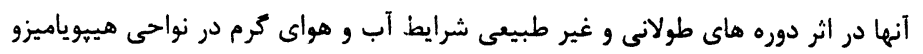

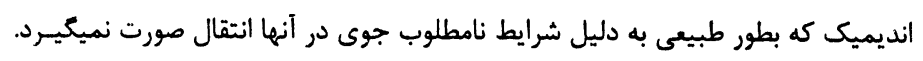

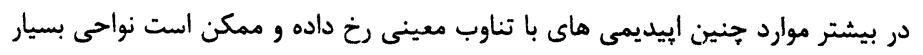

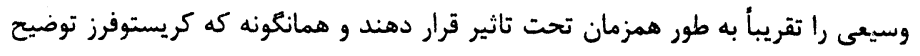

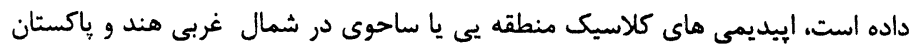

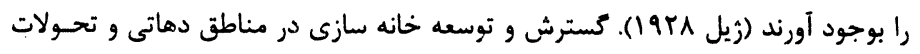

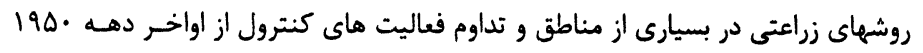

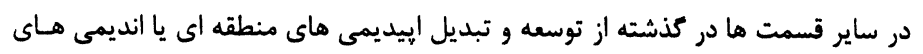

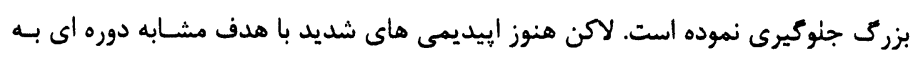

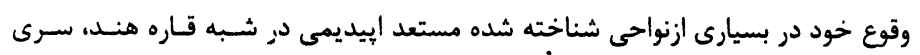

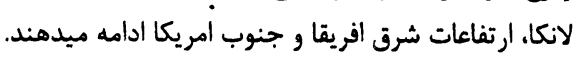

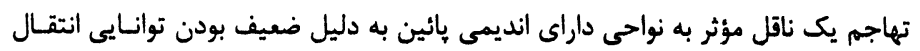
ii

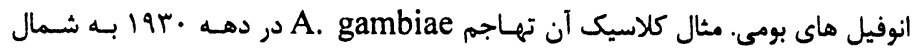

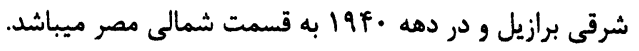

تغييرات اصلاحى محيط زيست: كه ممكن است هم موجب افـزايش و فـور ناقـل و هـم ازديـاد تحركيت اجتماع يا مردم شوند

تغييرات اصلاحى محيط زيست براى توسعه كشاورزى سـبب فـراهم آوردن شـرايط i

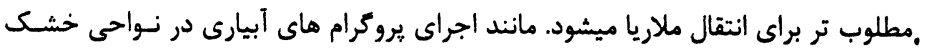

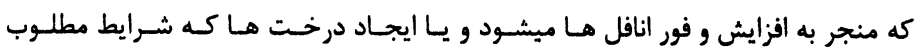

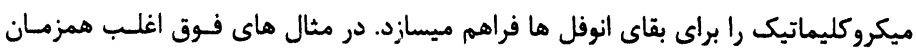

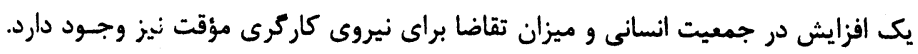

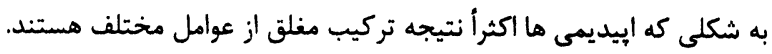

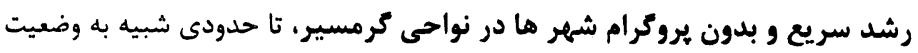
.ii

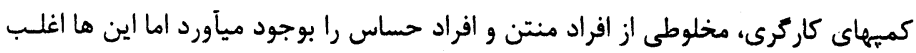

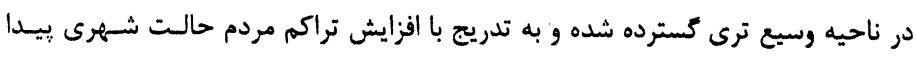

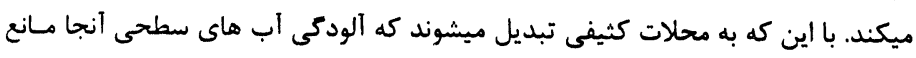

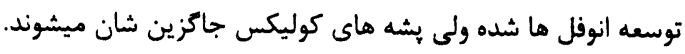


شكست در حفظ كنترول مؤثر قبلى: يس از معرفى عمومى يروكرام هاى ملسى كنتـرول ملاريـا

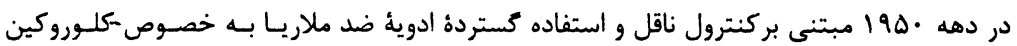

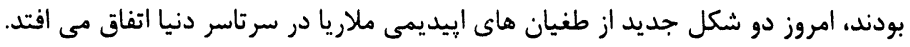

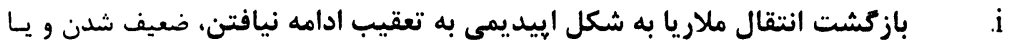

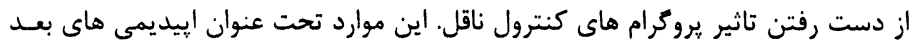

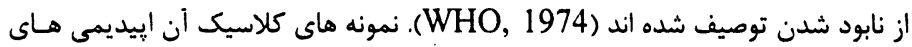

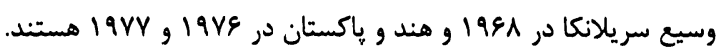

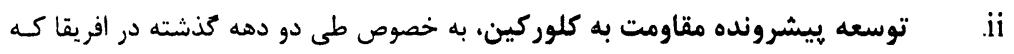

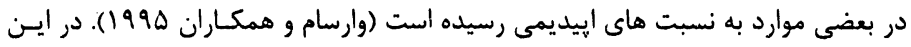

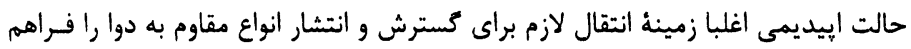
ميسازد (شارما و همكاران (1994).

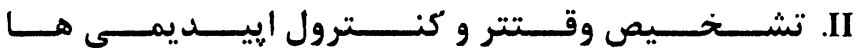

\section{EARLY DETECTION AND CONTROL OF EPIDEMICS}

ه. شناسايى و بررسى الييديمولوزيك (Recognition and Epidemiological Investigation)

إيديمى هاى ملاريا در نواحى مستعد إيديمى به ندرت در سطوح محلى با مشكلات در تشـخيص مواجسه ميشـوند و

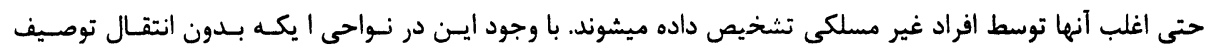

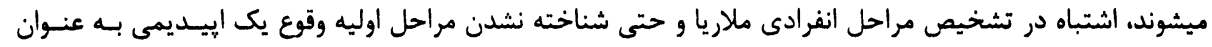

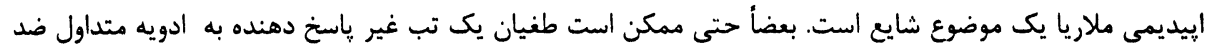

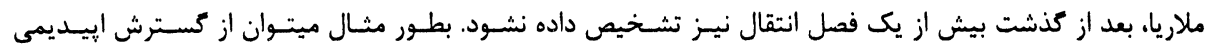

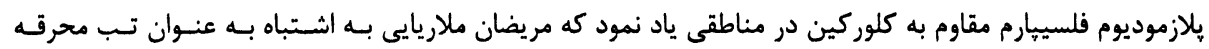

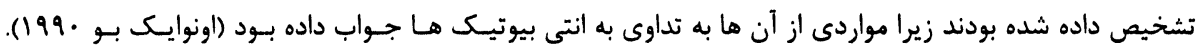

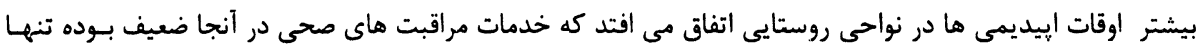

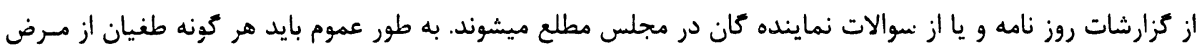

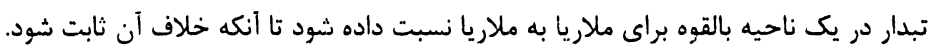

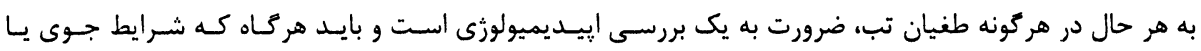

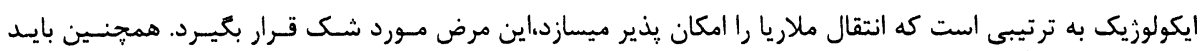

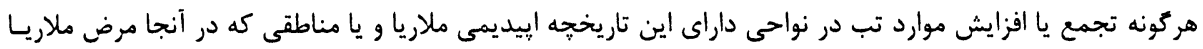

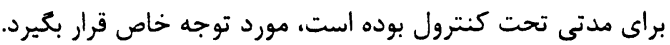


هنابع اوليه اطلاعات (نظير كزارشات واحد هاى محلى مبارزه با ملاريا و يا صحت عامه، ساير منابع رسمى، اخبـار......)

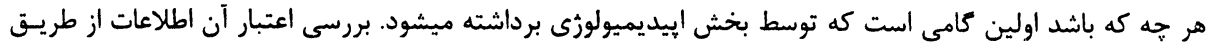

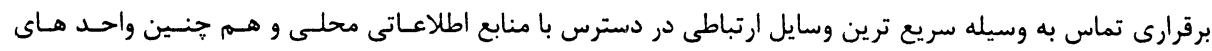

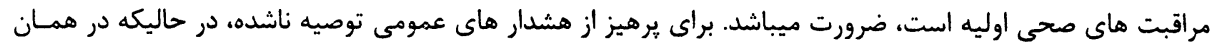

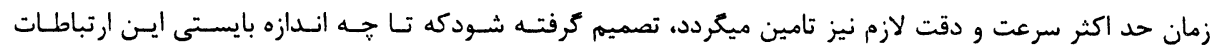

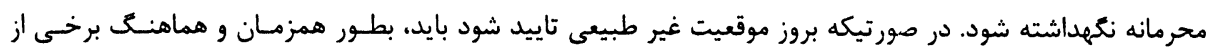
فعاليت هاى ذيل انجام كيرد.

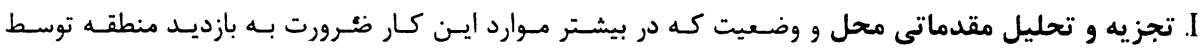

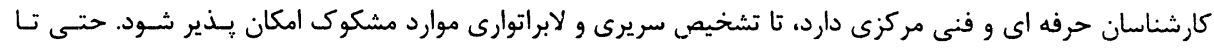

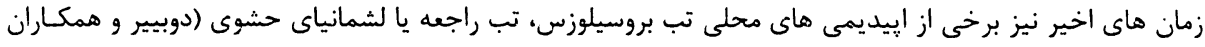

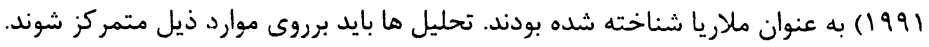

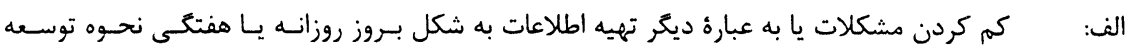

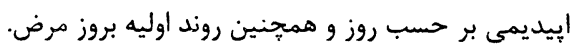

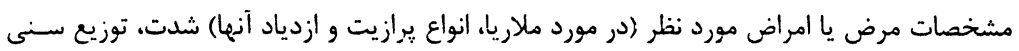

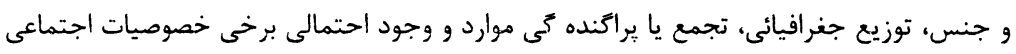

$$
\text { (شغل، محل استخدام .......) }
$$

ارزيابى عوامل مغلق سازى وضعيت اقتصادى و اجتماعى از قبيل ناموفق بـودن محصـولات زراعتى

$$
\text { قحطى، بى جا شدن مردم. }
$$

ارزيابى منابع محلى موجود براى مقابله با مشكلات ذيل مردم.

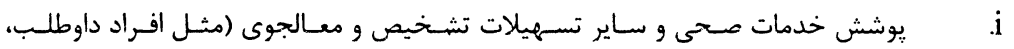

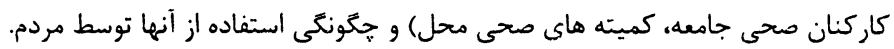

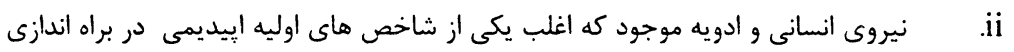

$$
\begin{aligned}
& \text { سريع تداركات دوايى در برخى نواحى محيطى است أنى } \\
& \text { هـ- يشتيبانى تداركاتى جهت ارجاع موارد }
\end{aligned}
$$

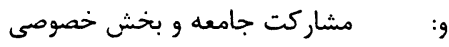

ز: همكارى هاى بين البخشى و در صورتيكه إيبديمى به دليل ملاريا نباشد، ضرورى است كه ارزيـابى

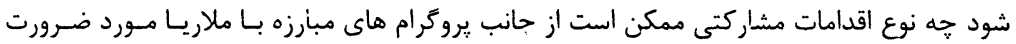

$$
\text { ضرورت براى حمايت و تقويت همكارى هاى درون و بين البخشى. }
$$

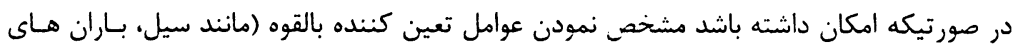

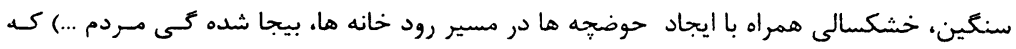
ممكن است قبل از إيبديمى اتفاق افتاده باشند.

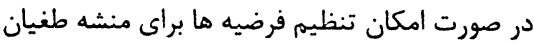




\section{WHO/MAL/98.1084}

\section{صفحس \&}

مشخص نمودن حدود جغرافيايى مشكل از طريق بررسى تيلفونى و يا بازديــد محلى نـواحى، مجـاور يـاـ . II

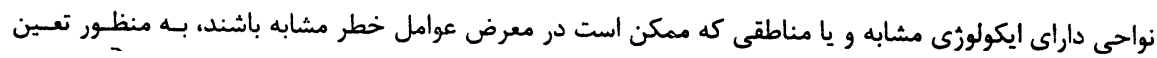

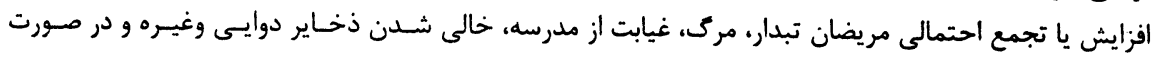

$$
\text { ضرورت: }
$$

الف: به شرط اينكه منابع انسانى ومواد آزمايشكاهى اجازه دهد، انجام يك بررسى ملأريومتريـى شـامل بر رسـى

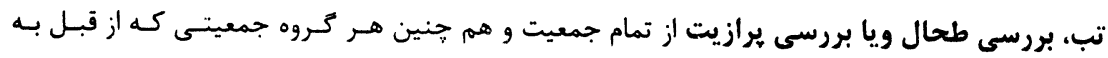

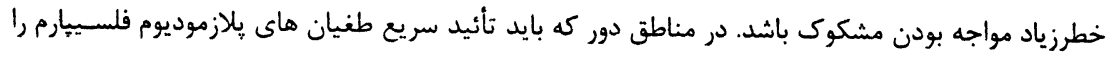

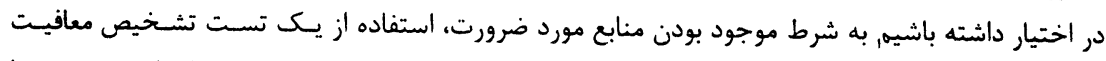

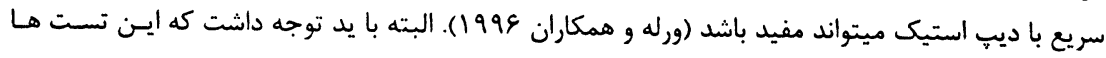

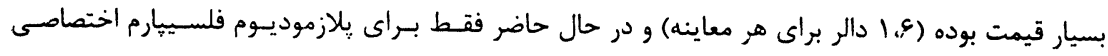

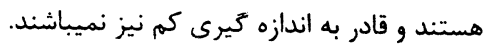

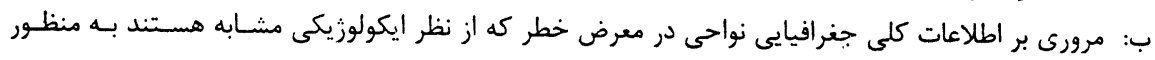

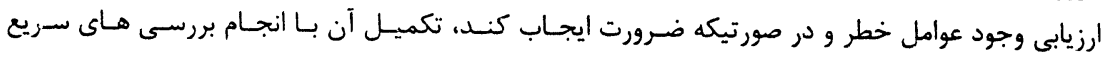

جغرافيايى.

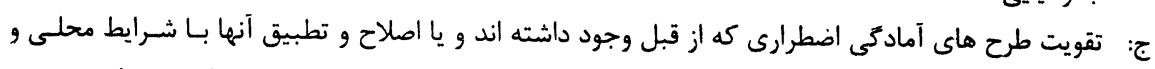
هم جنين ايجاد يك سيستم مشاهد وى براى بررسى وقوع عوامل معين يا يوتنسيال خطر در در منطقه.

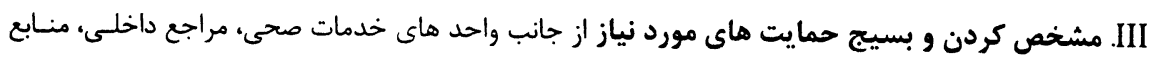

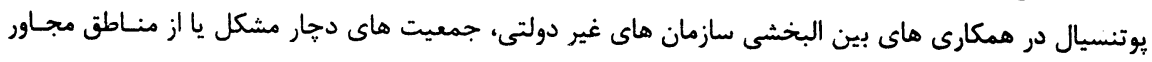

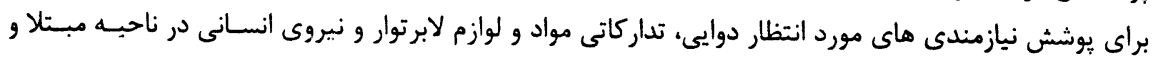
نواحى در معرض خطر.

بسيج منابع تداركاتى مورد نياز براى هر نوع حمايت لازم و يا هوشداردادن به كسانى كه مسؤول آنها. IV

هستند.

\section{ه. ب. بررسى الييديميولوزيكى}

تجزيه و تحليل مقدماتى بايد اطلاعات كافى در مورد مشخص نمـودن نـواحى تحست تـاثير قـرار ترفتـه و نـواحى در

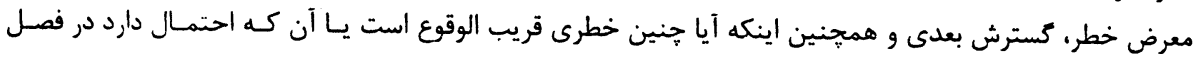

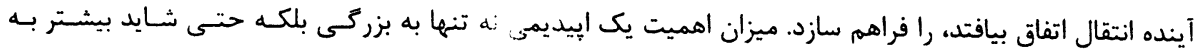

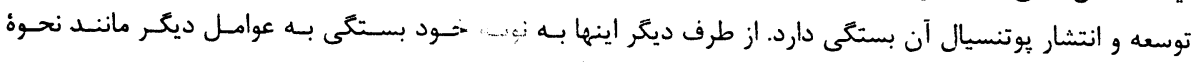

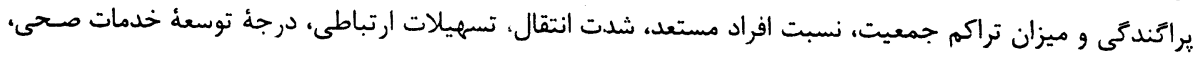

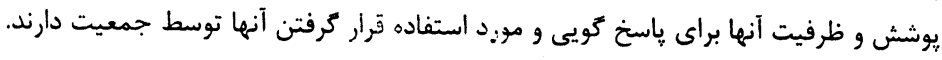

در هر حال طراحى يك بررسى إيديميولوزيكى صحيح و م:اسب ضرورى است. اجزاى ابن بررسى عبارت اند از:

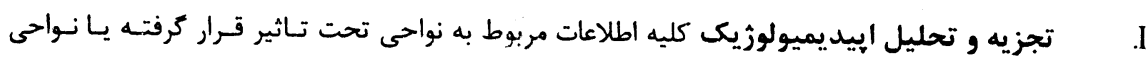




\section{WHO/MAL/98.1084}

\section{pio}

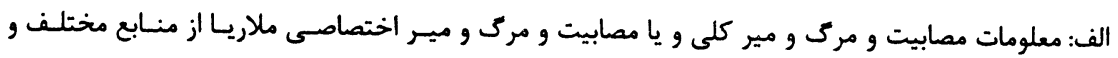

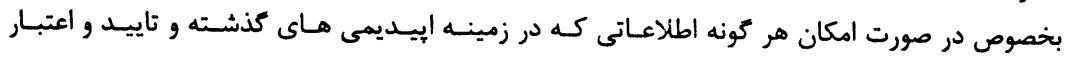

$$
\text { تشخيص هاى قبلى موجود است. }
$$

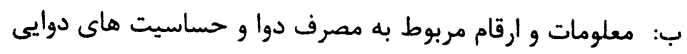

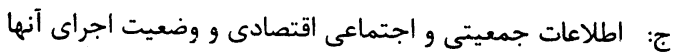

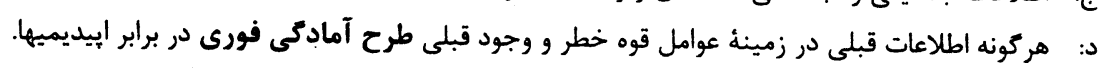

تقويت مراقبت هاى الييديميولوزى و خدمات لابراتوارى در كليه نواحى ايكه بايد براى اين منظـور

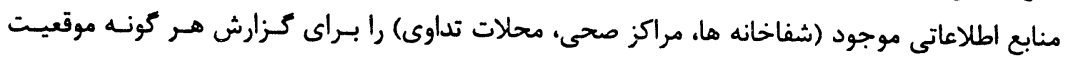
هشدار دهنده با سريع ترين وسايل ممكن آكاه نمود.

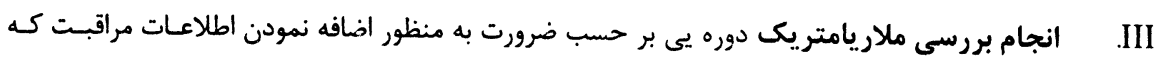

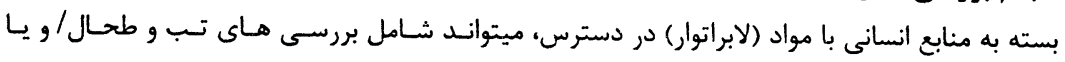

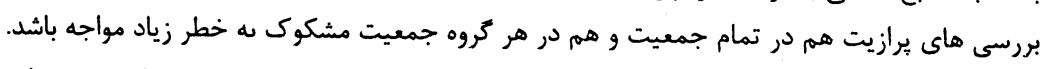

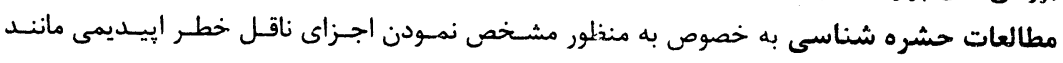

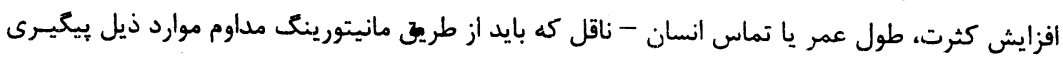

شود:

الف: يراكندكى ناقل، مكان هاى اصلى تكثير و هر نوع تغييراتى كه ممكن است در آنها اتفاق بيافتد.

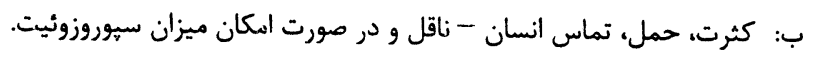

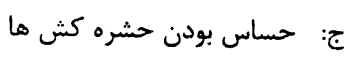

צ. كنترول وضعيت هاى الييديمى(Control of Epidemic Situation): اهداف اصلى برنامه هاى كنترول بايد شامل موارد ذيل باشد:

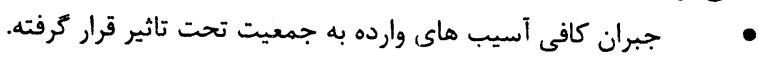

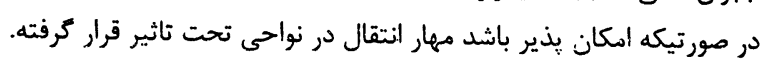

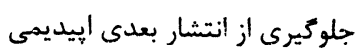
بهبود آمادكى فورى براى وقايه از اييديمى هارى آيديدي آينده

دو هدف اول نيازمند به كار هر حه سريعتر مداخلات مؤثر كنترولى هستند در حاليكه دو هـدف آخـر، انجـام ارزيسابى خطر و كار برد اقدامات وقايوى رادر بر ميكيديرند كه در بخش سوم در قسمت ب آن مورد بحث قرار خواهند كرفت.

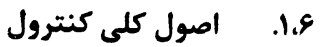

بايد تاكيد نمود كه إيديمى ها نه تنها از نظر سير و حركت (ديناميزم) بلكه از لحاظ جكونكى بايان يافتن و همجنين

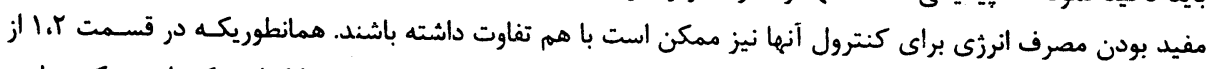

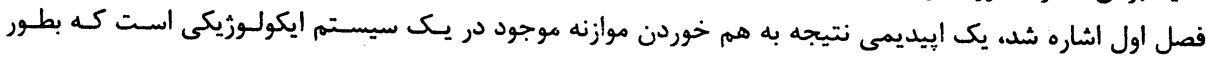




\section{WHO/MAL/98.1084}

\section{صفه Y Y}

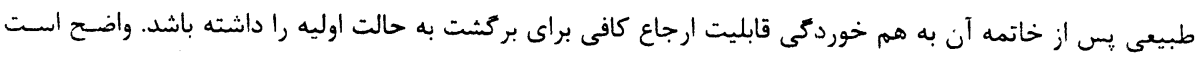

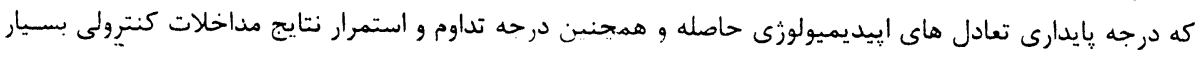

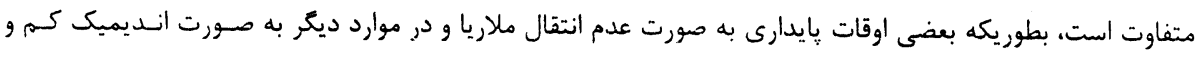

ممكن است يكنوع تشبيه ريشه شناسى به شكلى ا ين نظريات را ترسم كند هماكونه كه در مقدمه توضيح داده شـد.

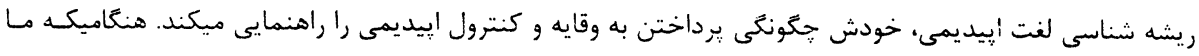

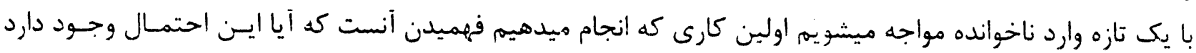

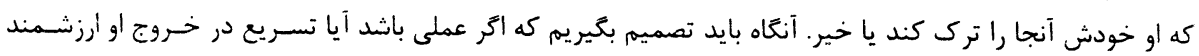

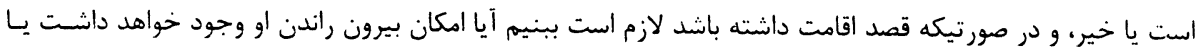

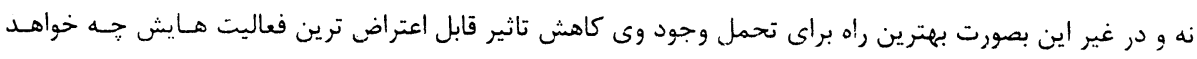

بنابر اين اولين قدم در ريرداختن به يك إيبديمى تصميمر گيرى و تعين اين موضوع است كه آيا آن ابيديمى: يك آشفتگى طبيعى در يك تعادل هايدار غير ملاريا خيز است كه نهايتاً خودش به انتها ميرسـد؟ كـه ايسن

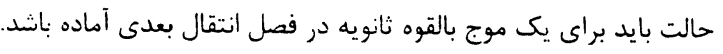

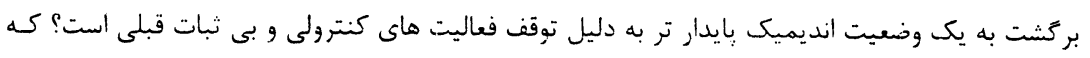

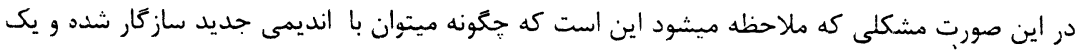

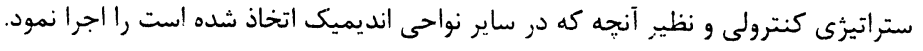

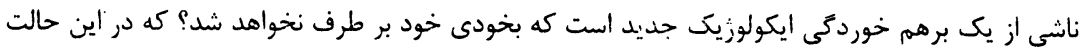

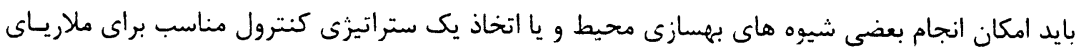

$$
\text { انديميك در نظر كرفته شود. }
$$

همجنان انتخاب و تقسيم اوقات فعاليت هاى كنترول نيز بايد بـر مبنــاى ايسن تصـميمات انجـام شـود. در مقابـل، در

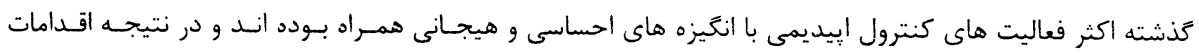

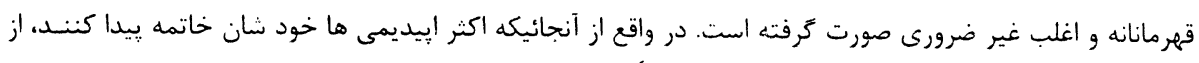

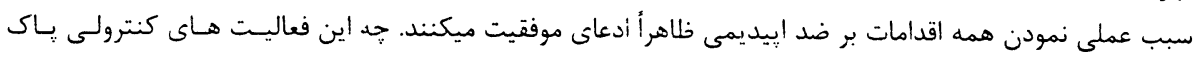

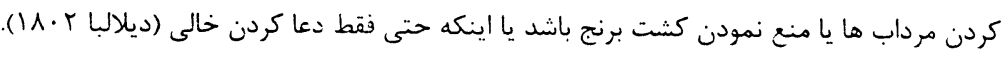

متاسفانه يك عكس العمل شايع در برابر إيديمى هائ ملاريا بسيج تمامى منابع موجود براى اجراى اقدامات كنتـرول

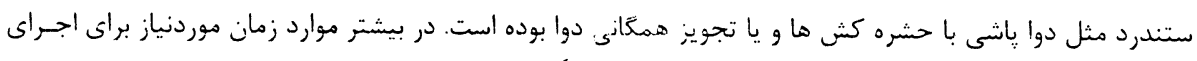

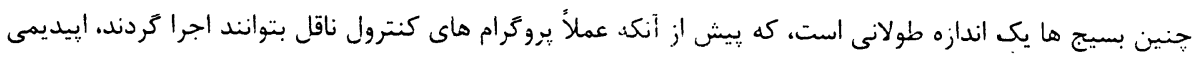

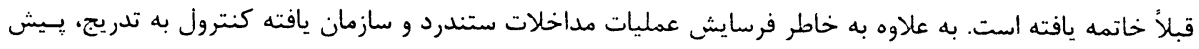

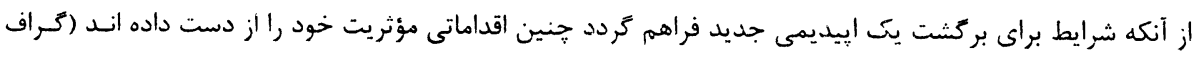


WHO/MAL/98.1084

PV صفحه

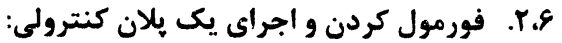

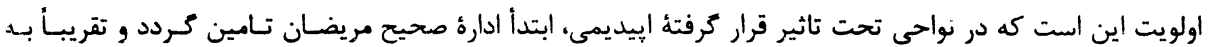

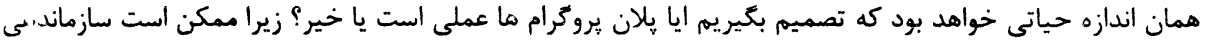

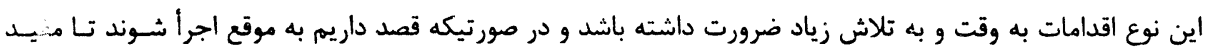

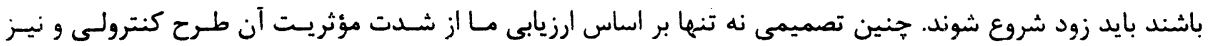

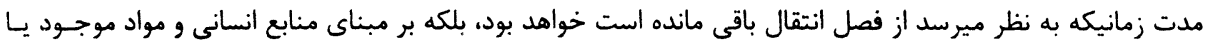

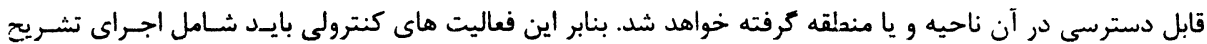
شدة ذيل باشند:

تو.r.r. اقدامات خيريه ورفاهى

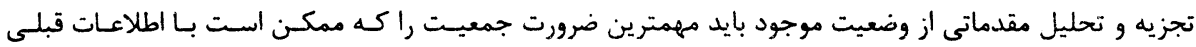
متفاوت باشند مشخص نمايد، كه ميتواند شامل ضرورت هاى اساسى مانند رفع قحطى باشد كه بـهـ همـان انـدازه كـهـ

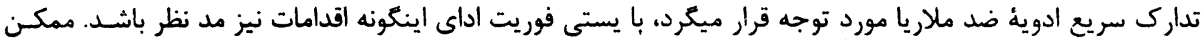

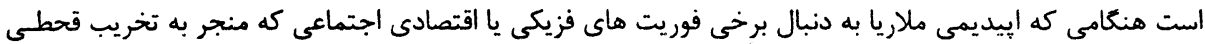

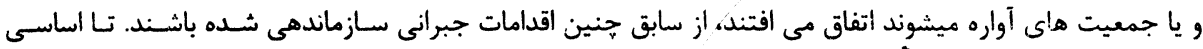

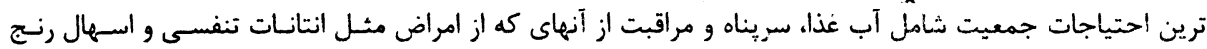

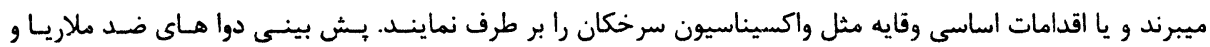

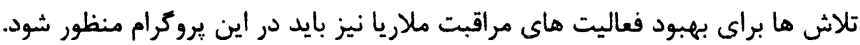

\section{r.r.r.r.r.}

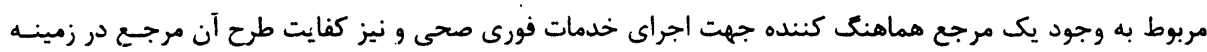

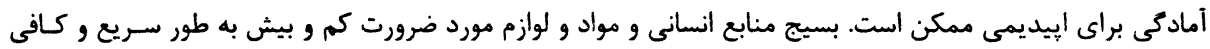

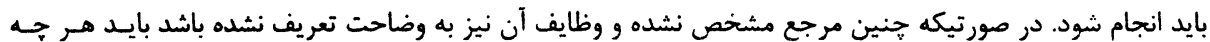

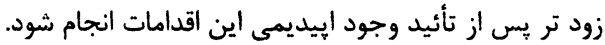

بسته به بزركى إيديمى و ظرفيت محلى عكس العمل فورى بايد مرجع هماهنك كننده بيشتبانى يا ايجاد يك كميته

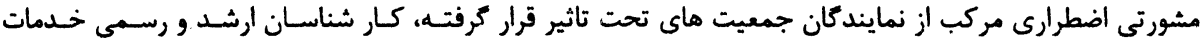

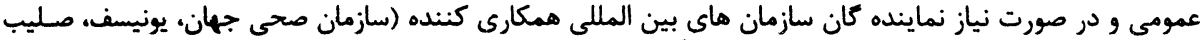

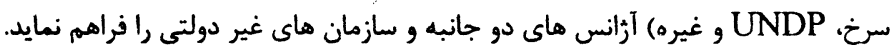

بر قرارى ارتباط ميان إيديمولورزست هاى ساحوى، واحد هاى محلى خدمات صحى و مرجع هماهنك كننده ضرورى

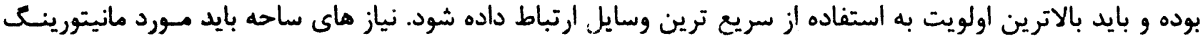

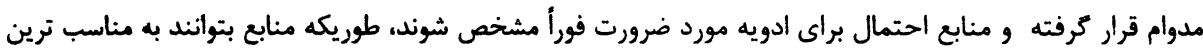
شكل در باسخ به ضرورت هاى ساحوى بسيج شوند. 


\section{WHO/MAL/98.1084}

صفح YA

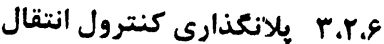

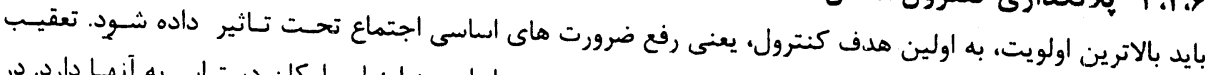

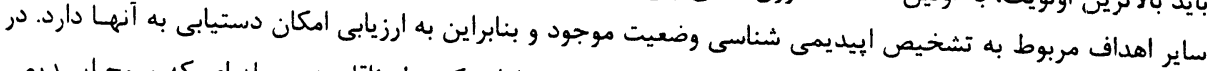

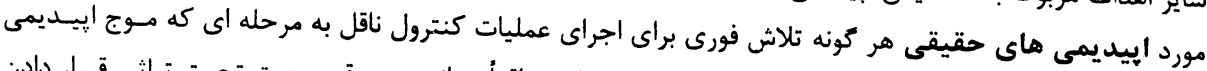

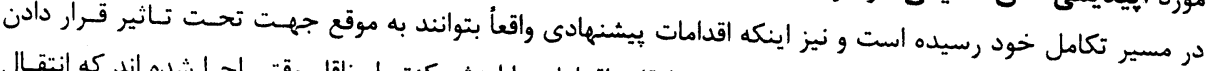

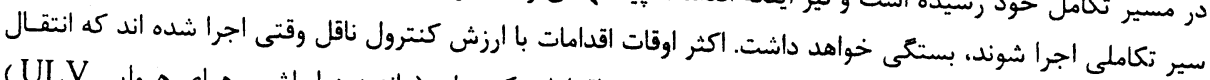

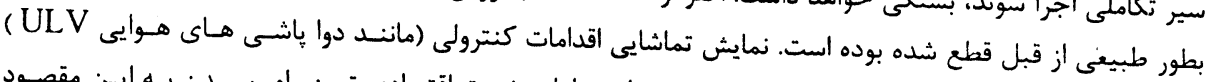

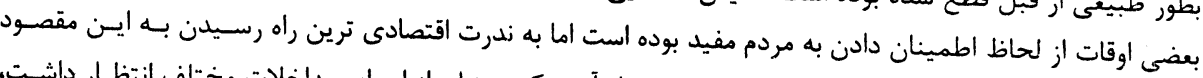

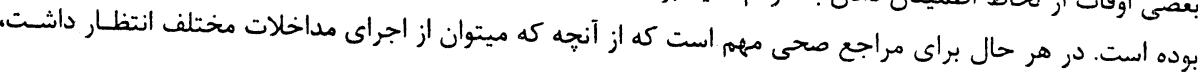
آتكاهى داشته باشد.

درصورت إييديمى هاى موضعى كه ناشى از تهاجم يك ناقل جديد و يا تمركز افراد غير ايمن در يك ناحيـه خـاص

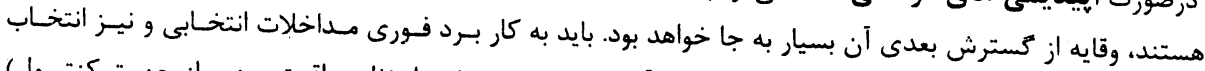

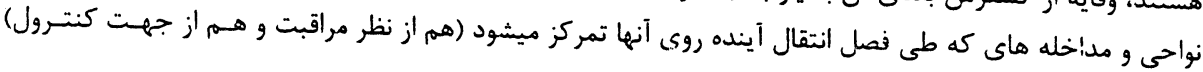
مورد توجه كامل قرار بكيرند.

در صورت بازتشت يا افزايش هتانسيل انديمى در تصميم كيرى براى اينكه آيا بايسد جهت تـلاش هـاى شكستـ

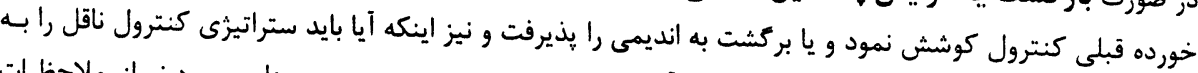

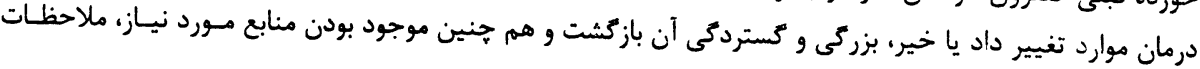

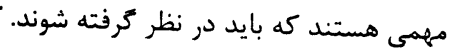

\section{(Disease Management) اداره كردن مرض}

I.V

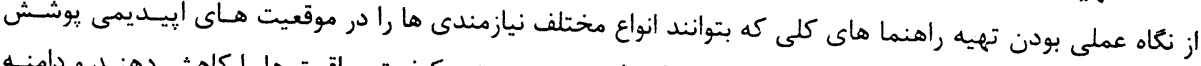

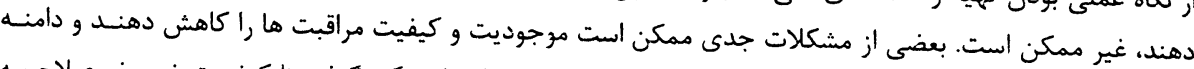

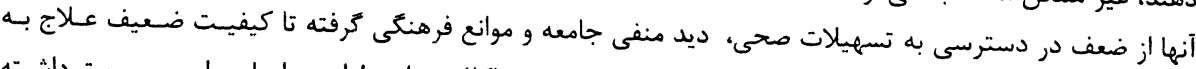

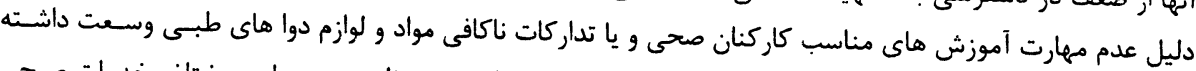

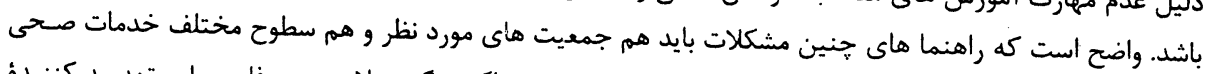

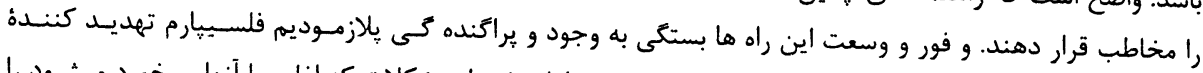

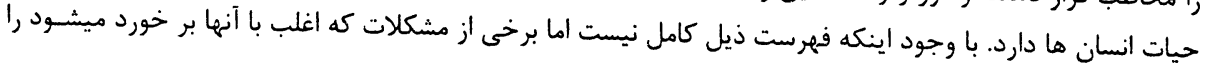

عملأ تمام إيديمى ها ضرورت بيشترى براى دوا هاى ضد ملاريا نسبت به تداركات اضافه اى كه بطور

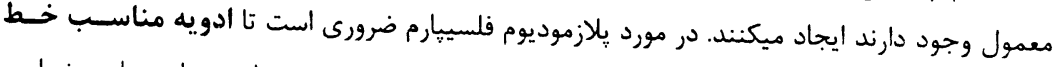

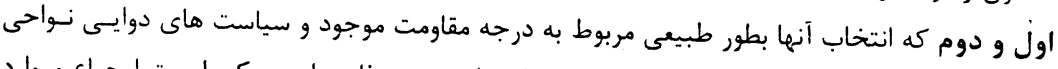

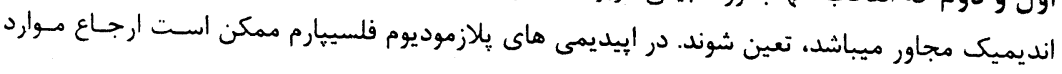




\section{WHO/MAL/98.1084}

\section{صفحه Y Y}

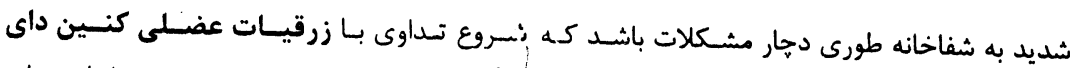

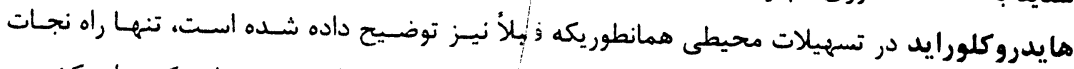

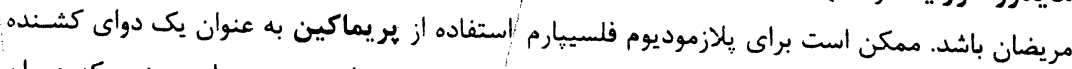

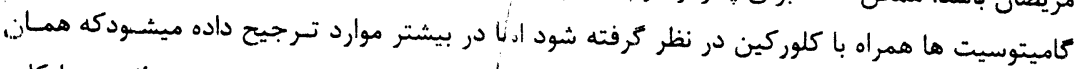

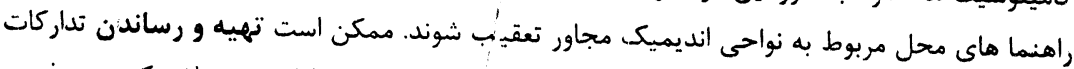

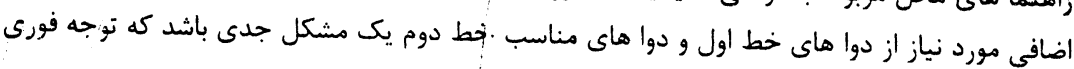

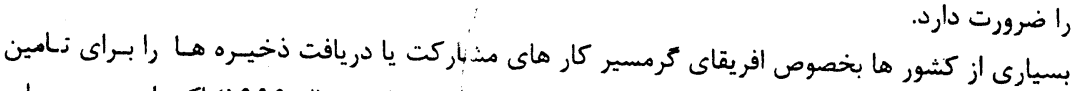

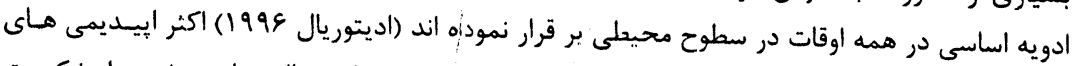

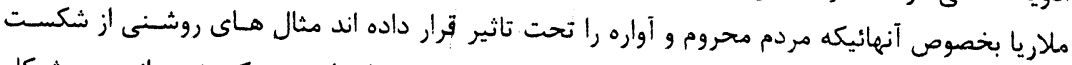

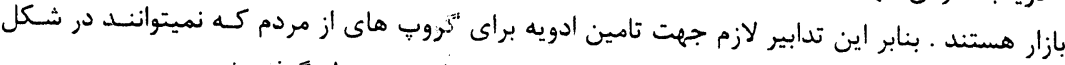

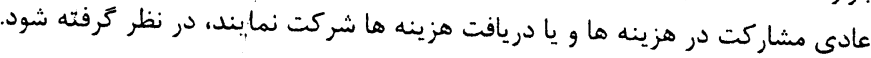

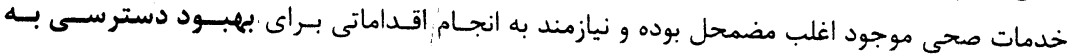

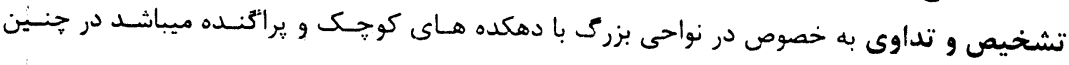

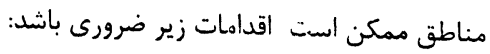

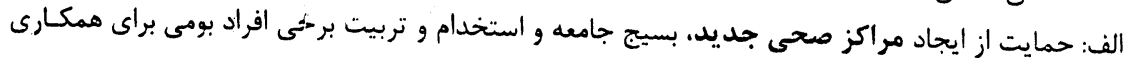

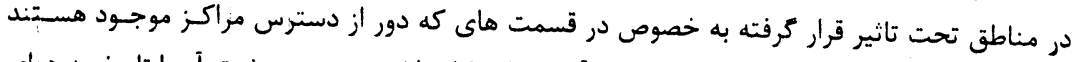

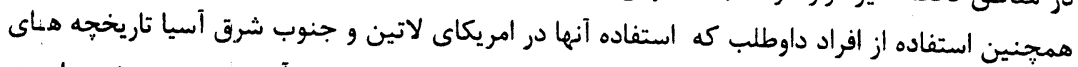

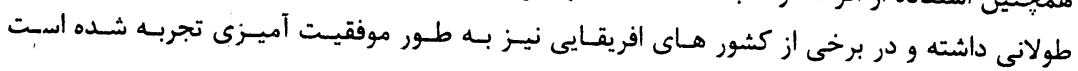

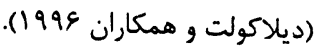

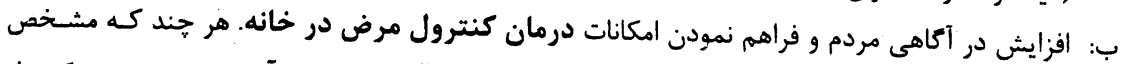

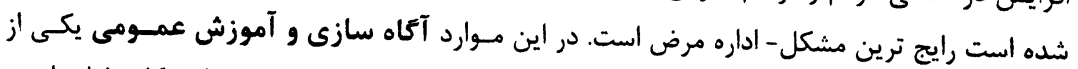

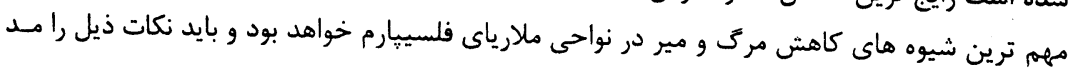

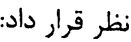
تاكيد بر اهميت شروع فورى تداوى با كلوركين در هر تونه تب همراه با لرزه بـه خصسوص در

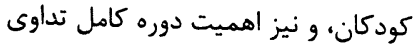

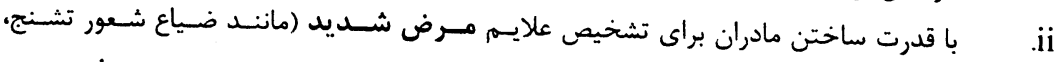

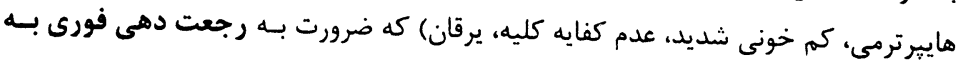
يك مركز صحى و يا شفاخانه ميباشد. iii

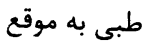

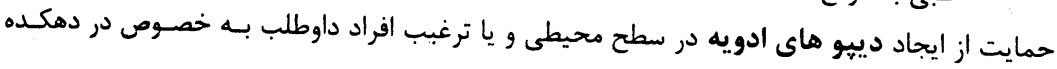
هاى كه به سادكى به مراكز صحى نزديك خود دسترسى ندارند. 


\section{WHO/MAL/98.1084}

صفحه

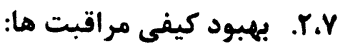

ممكن است به سبب بائين بودن تكرر قبلى مرض. كاركنان مرأكز مراقبت هاى صحى به خـوبى بـا نحسـوه اداره مـوارد

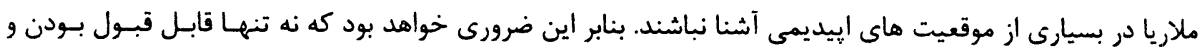

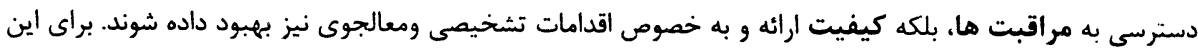
منظور ممكن است موارد ذيل ضرورى باشند:

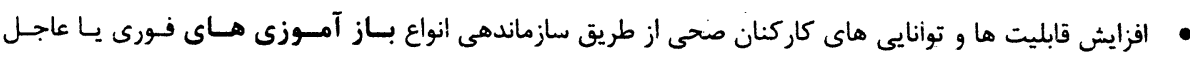

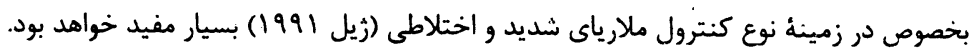

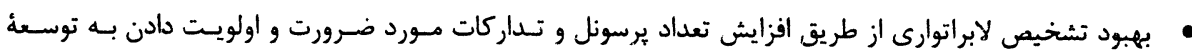
تشخيص ميكروسكويى ملاريا.

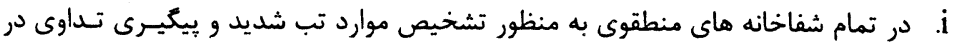
ملارياى شديد

ii

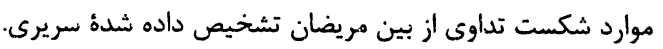

هم جنين ممكن است ارتقاى كيفيت ادارة موارد نر سطوح محيطى نيز ضرورت باشد. اكثر إيديمى هـا نـه تنهـا

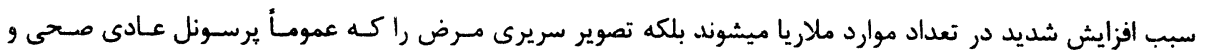

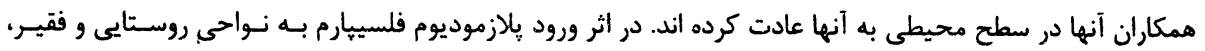

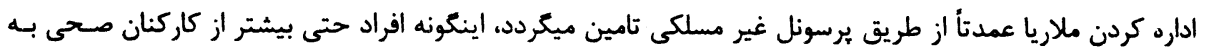

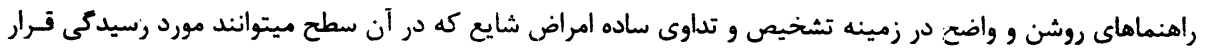

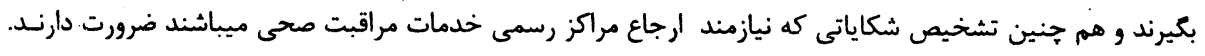

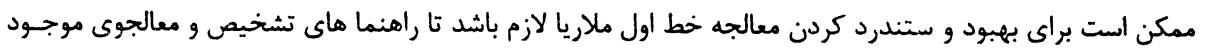

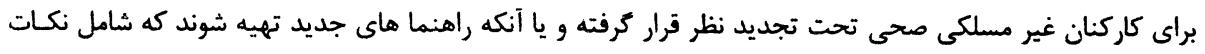
ذيل باشند.

تعريف سريرى مواردى كه ضرورت به تداوى دارند، ممكن است در مر حله حاد آيديمى تصميم كرفته شود كه

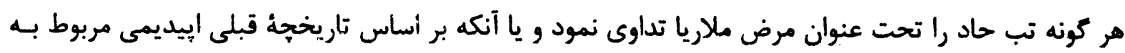

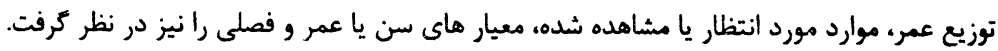

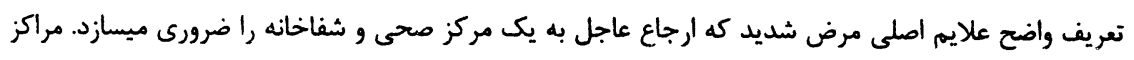

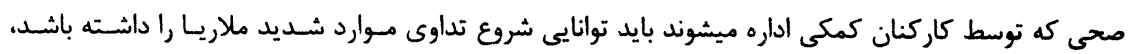

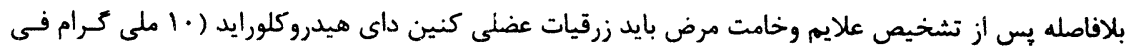

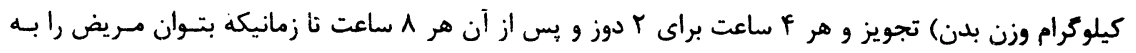

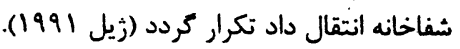

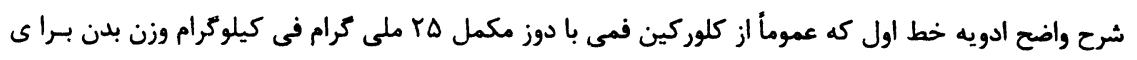

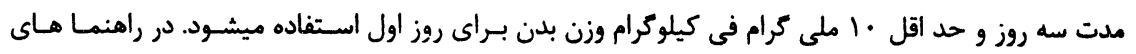

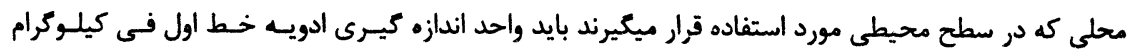


WHO/MAL/98.1084

صفحه

وزن بدن به تعداد تابليت ها براى هر كروب از نظر سن بر حسب قدرت دوايى تابليـت هـاى كـه در آن محسل موجود هستند تغيير داده شود.

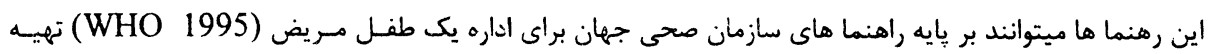

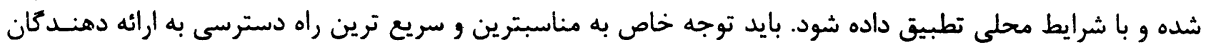

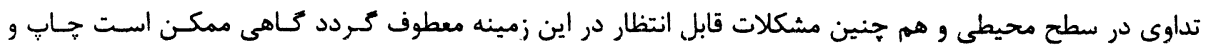

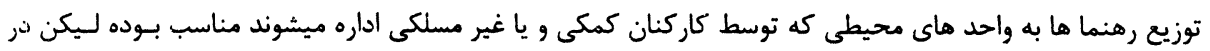

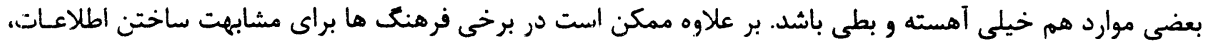

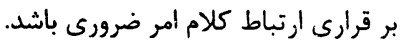

بايد تلاش نمود ادويه ضد ملارياى مورد استفاده در ناحيه مهاب بصورت ستندرد باشند، به عنوان مثال هر جاكـه

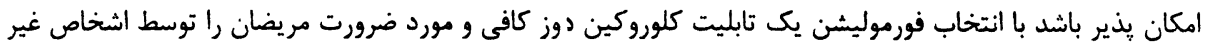

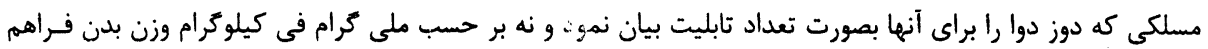

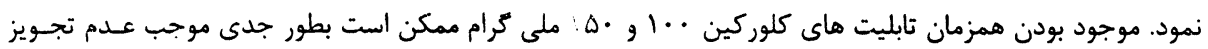

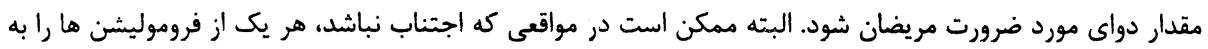

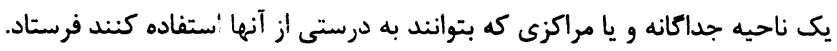

اغلب ضرورى خواهد بود كه مانيتورينك مؤثريت تداوى دوا هاى ضد ملاريا از راه هاى ذيل تقويت شود.

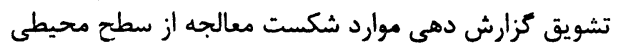

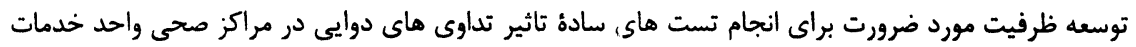

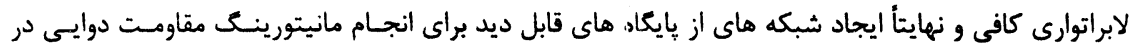

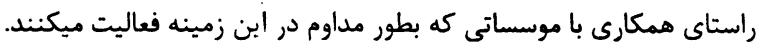

همجنين ضرورت خواهد بود كه تمام اطلاعات به دست آمده در زمينه تاثير معالجوى دواها، جهن تحقيق اين مطلسب

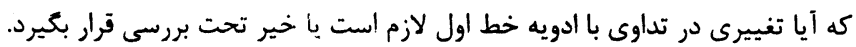

- V r.r. اطلاع رسانى عمومى و ارتباطات:

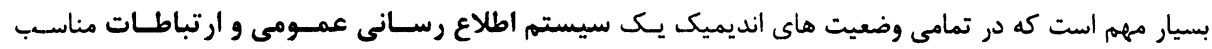

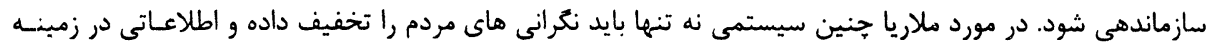

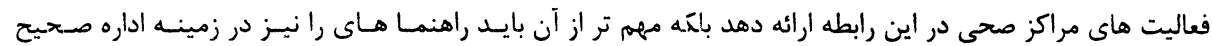

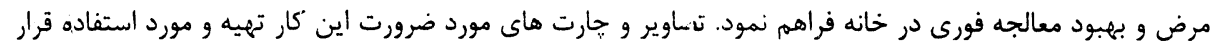

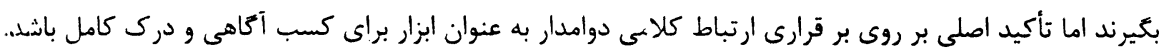

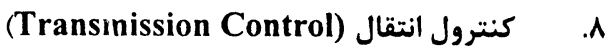

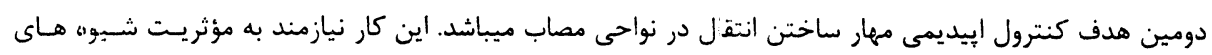

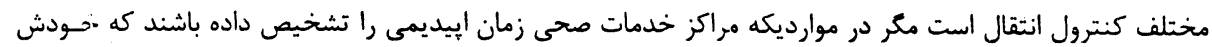

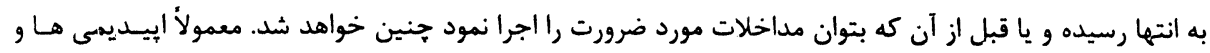




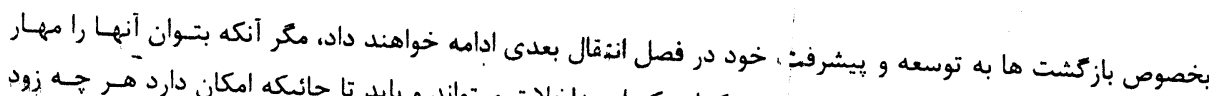

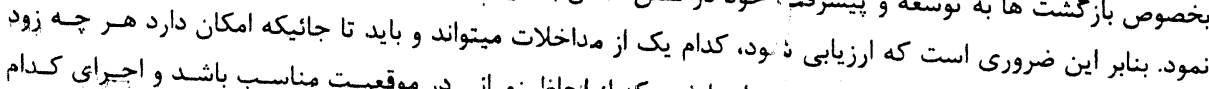

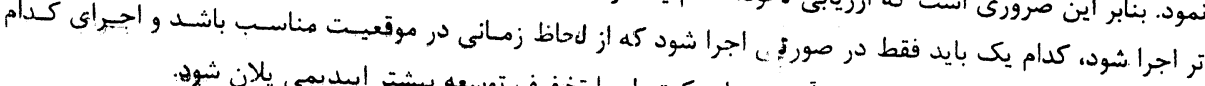

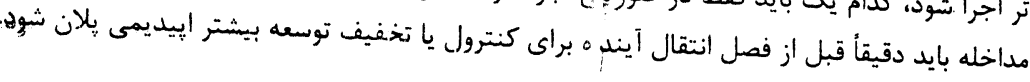

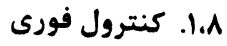

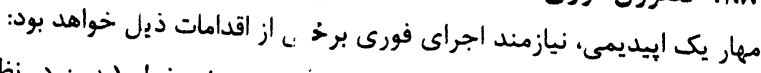

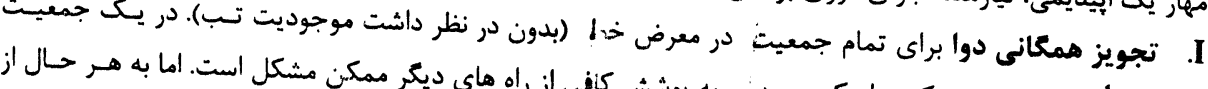

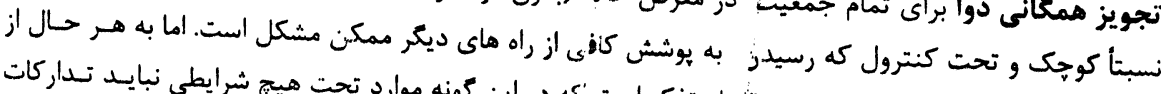

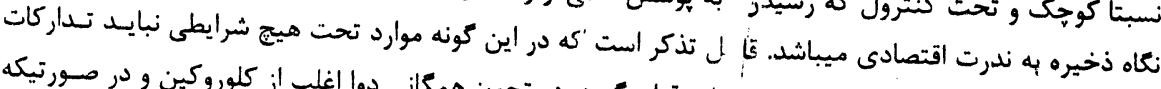

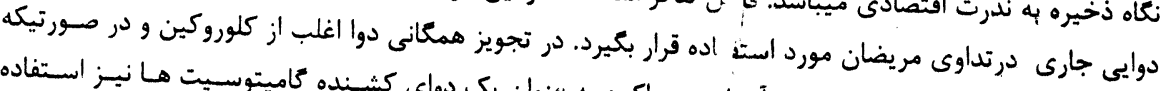

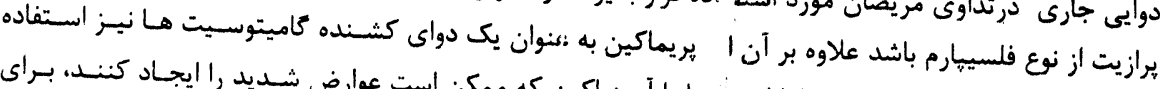

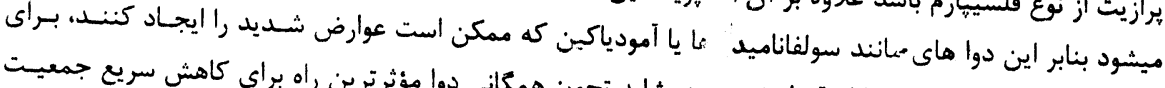

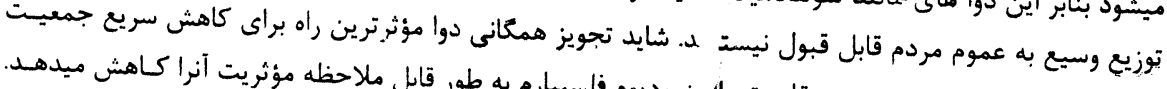

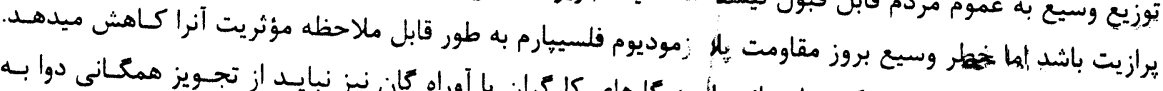

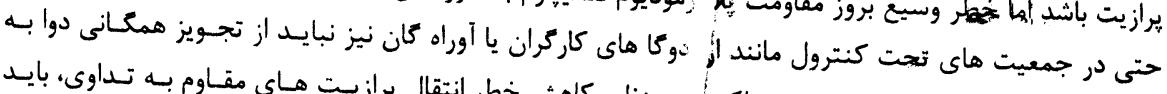

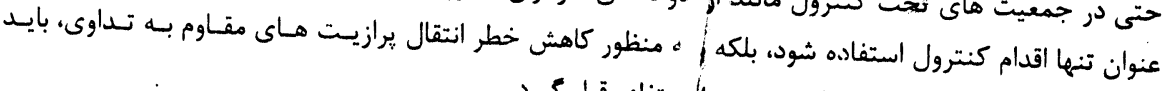

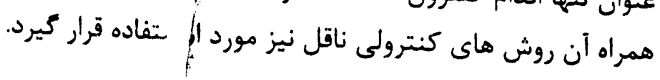

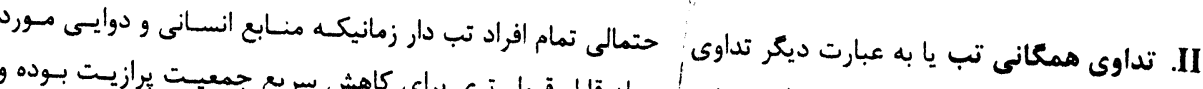

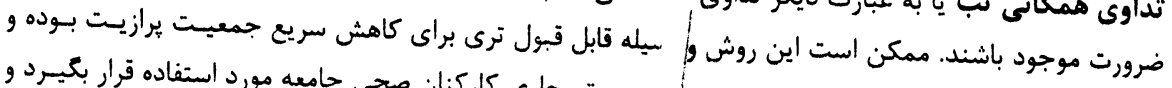

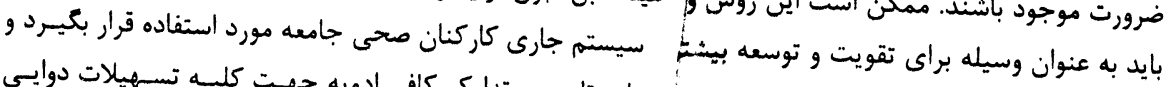

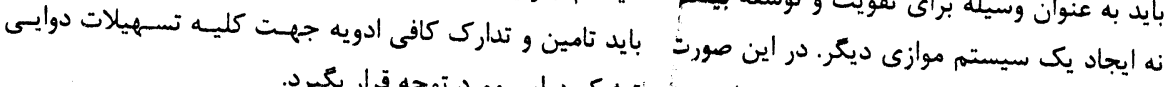

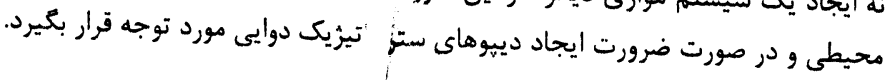

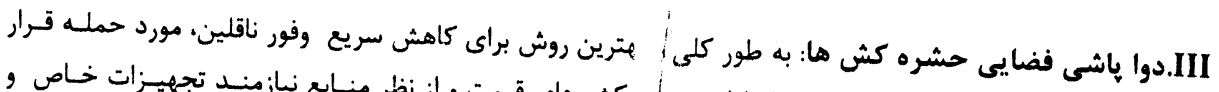

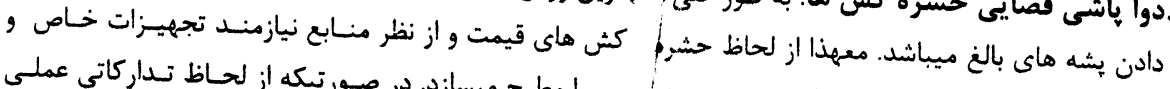

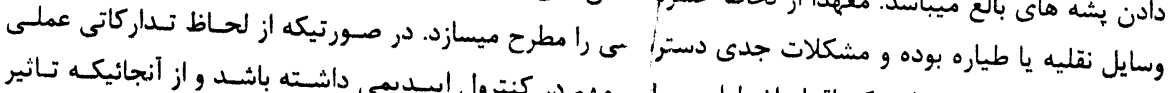

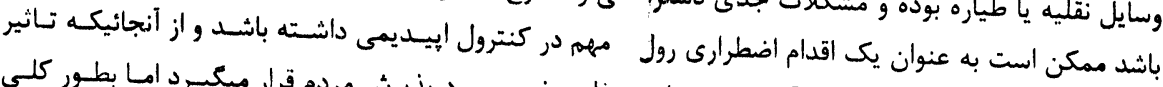

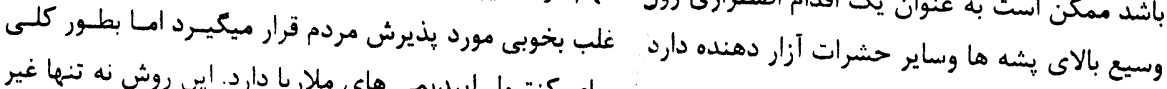

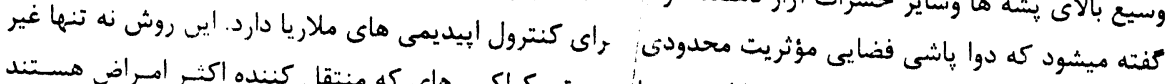

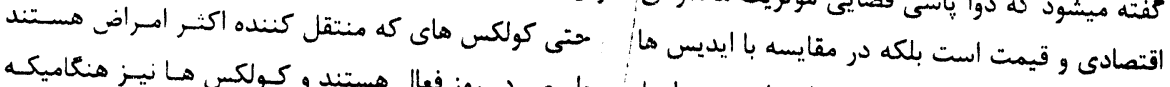

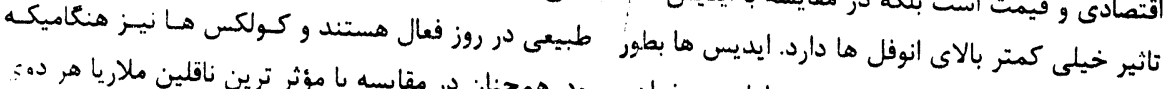

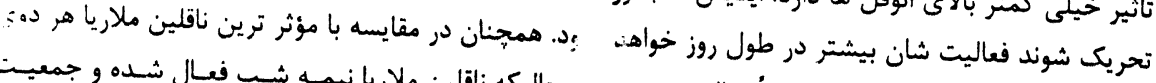

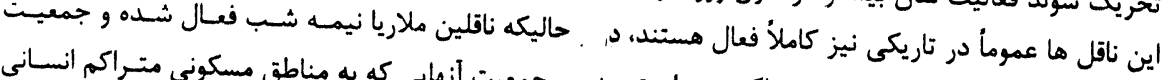

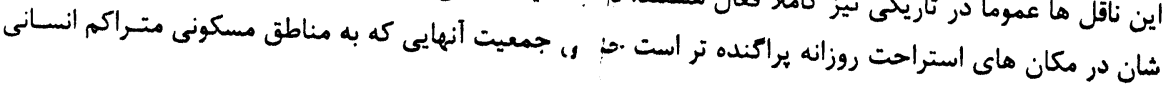




\section{WHO/MAL/98.11084}

صفحه rr

مانند كميهاى آواره كان حمله ميكنند، نيز يراكنده بوده و بدين ترتيب دسترسى به آنها ل،ر هنكام مهتابى كه نور

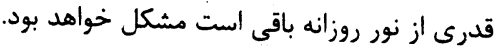

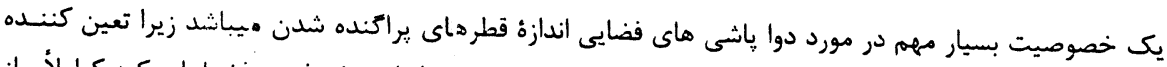

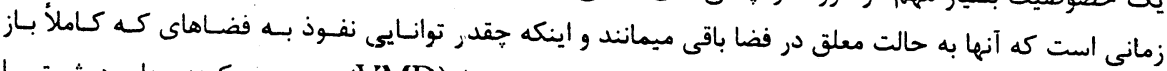

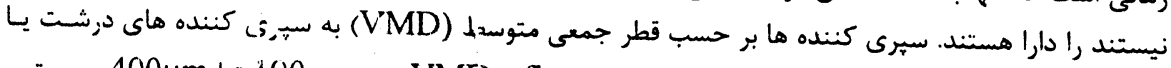

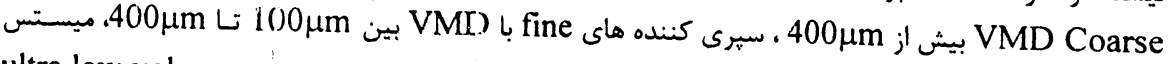

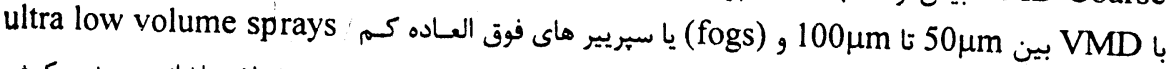

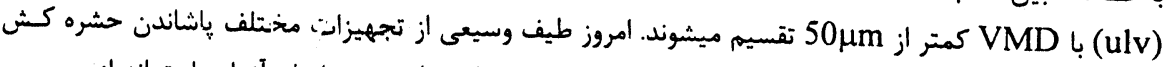

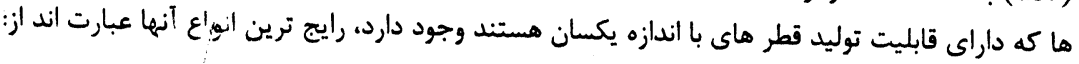

الف: مه باش هاى حرارتى و ميستس افكن ها كه سيار و مانند swingfog قابـل, حمـل هستـند و يـا آنكسه

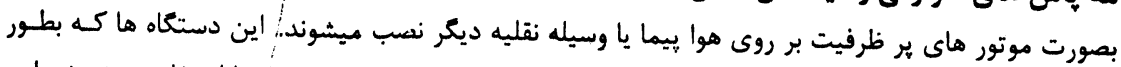

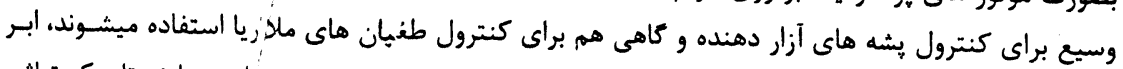

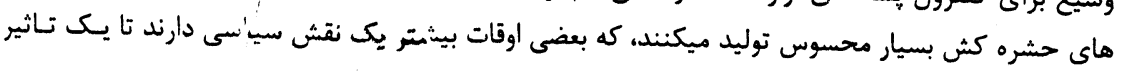

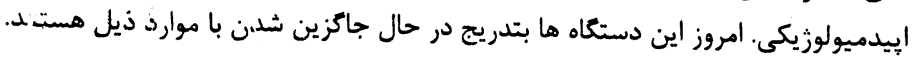

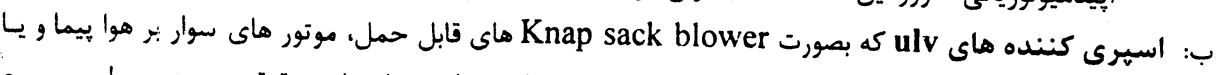

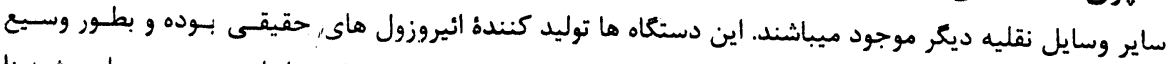

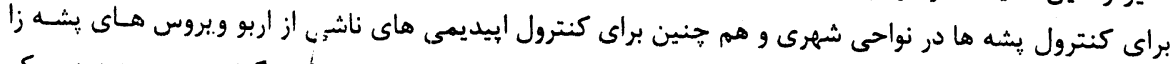

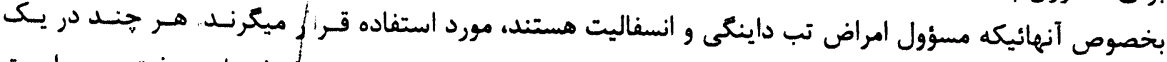

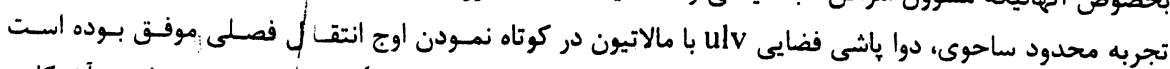

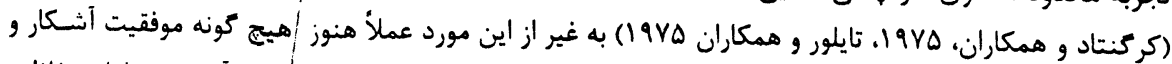

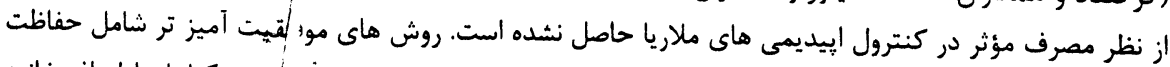

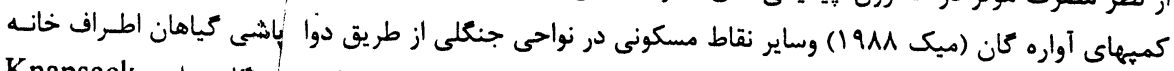

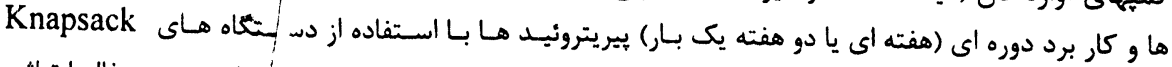
blower

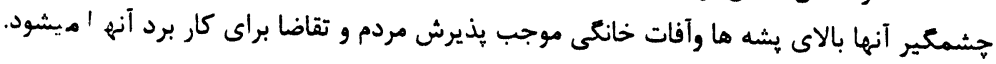

علاوه بر اين انواعى از بخش كننده ها براى بخش حشره كش ها در هوا وجود دارد كه عمدت 'از آنها براى كـاهش آزاد

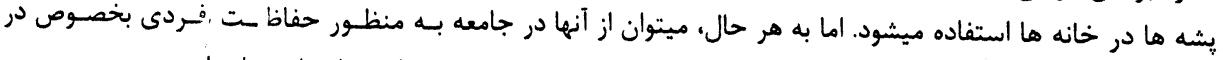

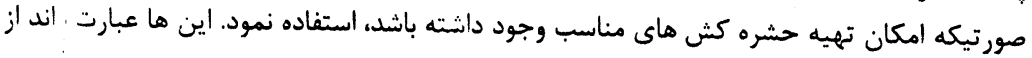
ج: تفنى هاى سريع (flit-guns) بطور وسيع براى كابرد هاى داخلى استفاده شده اند و حتمالأ ريتـوان بـه طـور وسيع آنها را تهيه نمود.

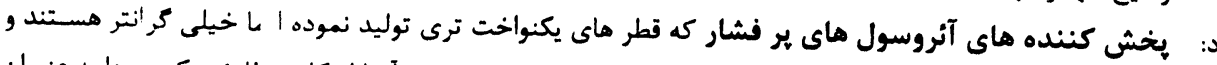

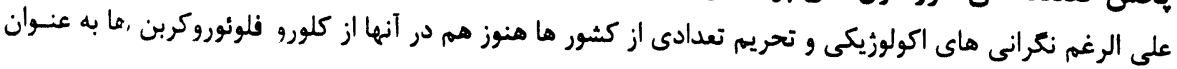




\section{WHO/MAL/98.1084}

\section{r\&}

هـ. توليد كننده هاى دود به شكل فنر هاى اندكه براى حفاظت فردى مورد استفاده قرار ميكيرند.

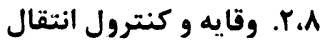

مهار يك إيديمى و به خصوص محدود كردن كسترش و وقايه از بركثت آن در فصول انتقال آينـده نيازمنسد بـهـ كار

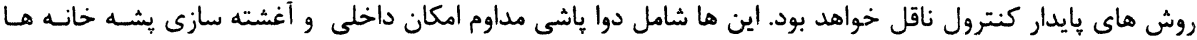
ميباشد كه رايج ترين روش هاى موجود هستند.

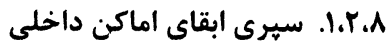

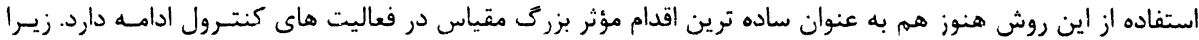

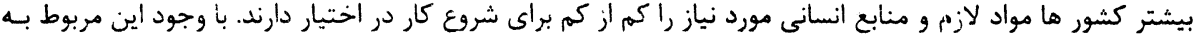

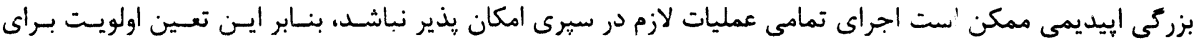

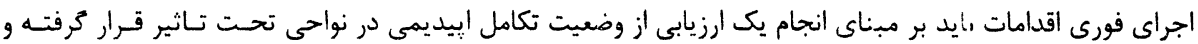

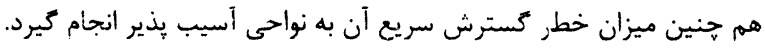

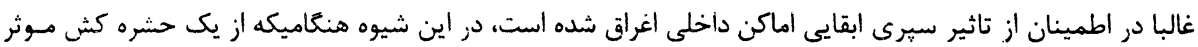

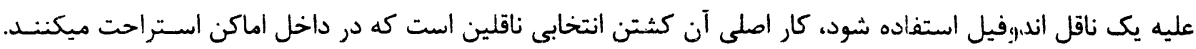

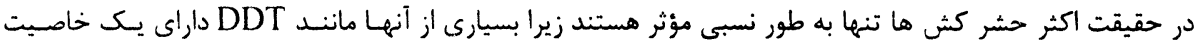

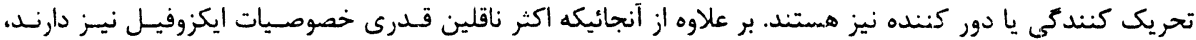

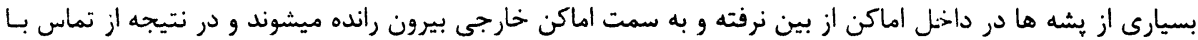

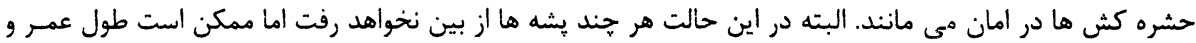
ظرفيت آنها كاهش يابد.

براى اينكه سيرى به منور كامل مؤثر باشد بأيد به بوشش كامل دست يافت. به عبار ديكر به منظور بقاى حشـره كـش

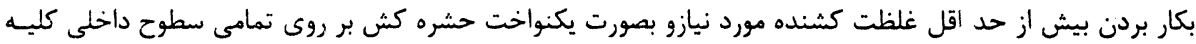

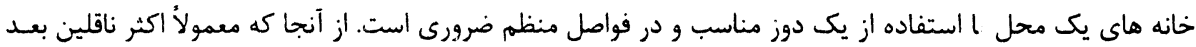

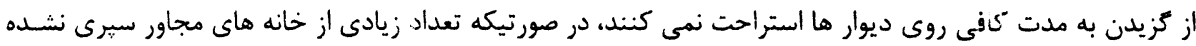

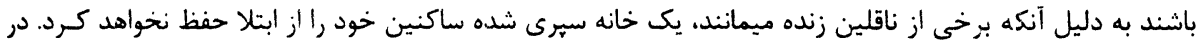

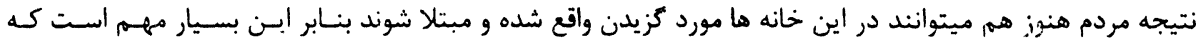

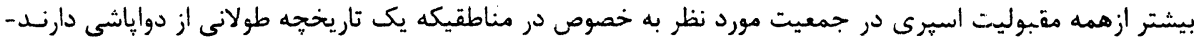

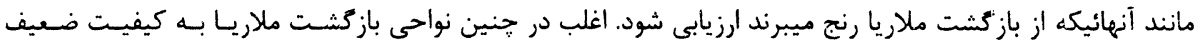

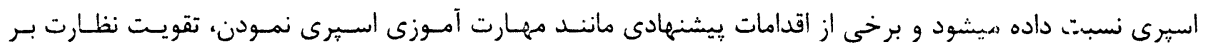

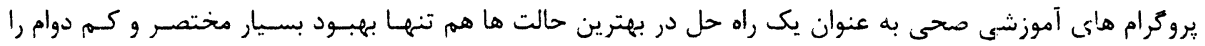

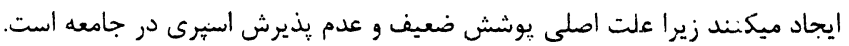

صرف نطر از مقبوليت، انتخاب سهرى أبقايى به عنوان روش براى كنترول ناقل بايد به اساس تعين حساسيت نـاقلين

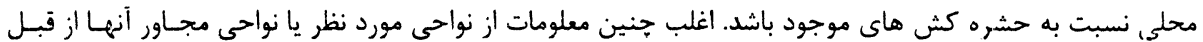

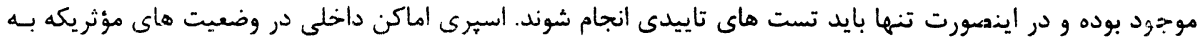




\section{WHO/MAL/98.1084}

\section{صفح or}

وضاحت بتوان آنها را مورد هدف قرار داد و انجام عمليات در يك مدت زمان عحدود صورت بكيرد و در جائيكه حتـى اكر سيرى دوره اي مورد نياز باشد بتوان مؤثريت و كيفيت آن را حفظظ نمودة.

در حنين وضعيت ها به جز كنترول فورى إييديمى موارد ذيل نيز در نظر كرفته شود: • كاهش پتانسيل انتقال در كروه هاى ازجمعيت كه از كيمويروفيلاكسى همعانى استفاده ميكند، مانند برخىى از كميهاى آواره كان يا در يروزه هاي توسعة اقتصادى. كاهش اوج إييديمى هاى فصلى از طريق اسيرى هاى منظم ساليانه به خصوص وقتهى كـه بـا يـك افـزايش. وسيع در جمعيت يشه هاى آزار دهنده همراه هستند به طوريكه يذيرش و رضايت جامعه فراهم گردد. • جلوكيرى از انتقال ملاريا در نواحى ايكه انتظار ميرود ابيديمى بركشت نمسوده و يـا در فصـل انتقـال بعـدى كسترش يابد. اين روش يكى از راه هاى اصلى وقايه از إيبديمى ها در نواحى كه سيستهر يسيش بينسى كنتـده افزايش خطر اييديمى را تشخيص داده است، نيز ميباشد. سميت حشره كش ها و مخاطراتى كه ممكن است براى كاركران سيرى، ساكنين خانه هاى اسـيرى شـده و هـما جنين براى معيط زيست داشته بأشد، نكرانى هاى اصلى باشند، به خصوص به دليسل غيسر ممكسن بسودن ممانعت از تماس مردم با سطوح اسهرى شده و هم جنين مشكل بودن استفاده از لـوازم حفـاظتى ييجيـيـده در شـرايط كرمسـير توسط كارگران اسيرى بايد فورموليشن هاى حشره كث هاى مورد استفاده در اماكن داخلى ايمن و بسى خطـر باشـد. همانطوريكه در جدول نشان داده شده است. ميزان سميت تركيب اصلى سموم بر حسب LDO خوراكى و تماسى در مبش ها اندازه گيرى ميشود كه خطر تام مسموميت حاد را مشخص ميكند. اما به هر حال خطر واقعى اسيرى ارتباط

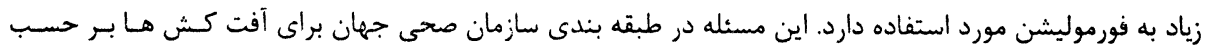
هخاطره (WHO/UNDP/ILO 1994) در نظر مرفته شده است كه طى آن سموم به طبقـات فـوق العـاده سـمى

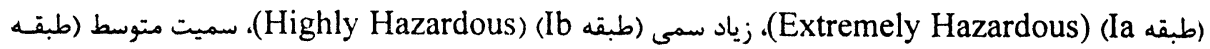

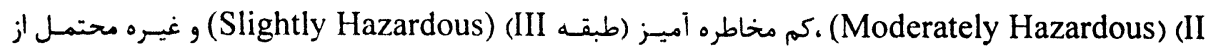
لحاظ مخاطره (طبقه (Unlikely to be hazardous) (UH ) تقسيم بندى ميشوند. سمومى كه معمولأ در كنترول ملاريا بيشنهاد ميشود و در جدول ا فهرست شده اند به استثنأ ملاتيون و يِيريميفوس ميتل كه در طبقه III هسـتند همكى به طبقه II تعلق دارند در حقيقت كليه فورمولهاى مورد استفاده در غلظل- هاى كه بكـار ميرونـد متلعق بـه طبقه

دوز و ميزان اثر ابقايى سموم، ملاحظات مهمى در تعين تعداد دوره هاى اسيرى براى حفاظـت از يـك جمعيست در

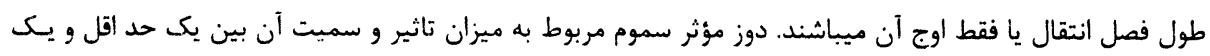

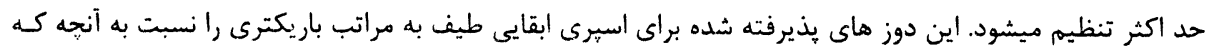

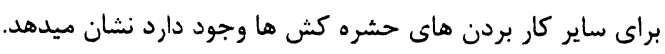


WHO/MAL/98.1084

صis

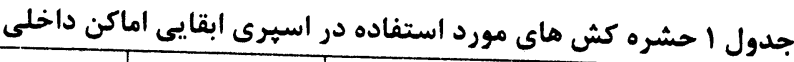

\begin{tabular}{|c|c|c|c|c|}
\hline $\begin{array}{l}\text { سميت خوراكى } \\
\text { (LDs) (mg/kg) }\end{array}$ & اثر ابقايى (ماه) & gوز & نوع & حشره كش \\
\hline 19 & 9-f & $\because \cdot r-\cdot . r r$ & PY & الفا سايبرمترين \\
\hline$\Delta \Delta$ & s-r & $\cdot .1-\cdot . f$ & $\mathrm{C}$ & بنديوكارب \\
\hline$r \Delta \cdot$ & $r-r$ & $1-r$ & $\mathrm{C}$ & كاربوسولفان \\
\hline$>r \ldots$ & $r-r$ & $\cdot . r r-1$ & $\mathrm{OP}$ & كلوربيريفوس منيل \\
\hline rQ. & s-r & $\because \cdot T-\cdots \cdot \Delta$ & PY & سايفلوترين \\
\hline$r \Delta$. & F ئيشتر يابشت & $\cdot . \Delta$ & PY & سايبرمترين \\
\hline $11 r$ & ع يا بيشتر & $1-r$ & $\mathrm{OC}$ & دى دى تى \\
\hline iro & $4-Y$ & $\because \cdot 1-\cdots$ TA & PY & ديلتامترين \\
\hline$>1 \ldots$ & 4-r & $1 ; \cdot \cdots \cdot r$ & PY & ايتوفنيروكس \\
\hline$\Delta \cdot r$ & $8-r$ & 2 & $\mathrm{OP}$ & فنيتروتيون \\
\hline$\Delta s$ & G-r & $\because \cdot r-\cdot . \cdot r$ & PY & لامبداسيهيالوترين \\
\hline$r \ldots$ & $r-r$ & $r$ & $\mathrm{OP}$ & ' مالاتيون \\
\hline$\Delta \cdots$ & $r-r$ & $\cdot 0$ & $\mathrm{PY}$ & بيرمترين \\
\hline$r \cdot 11$ & r-r با بيشتر & $1-r$ & $\mathrm{OP}$ & يريميميوس- متيل \\
\hline $9 \Delta$ & q-r & $r-1$ & $\mathrm{C}$ & برويوكسيور \\
\hline
\end{tabular}

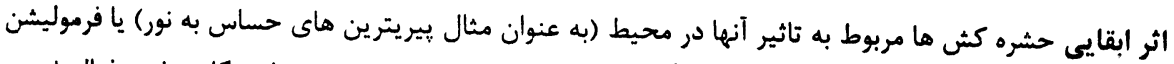

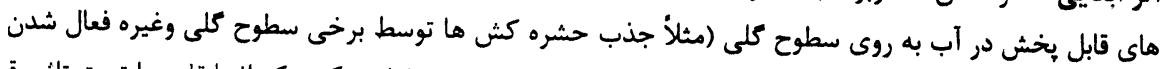

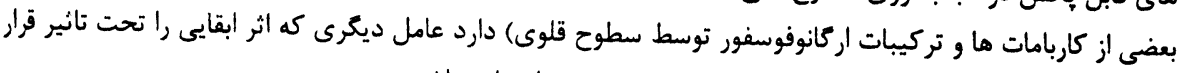

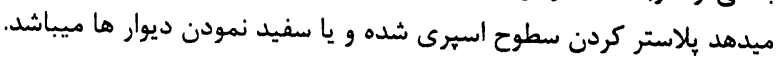

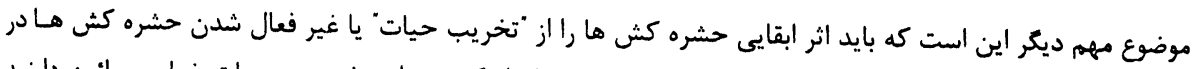

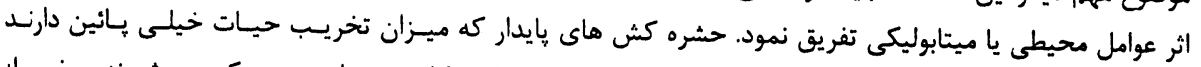

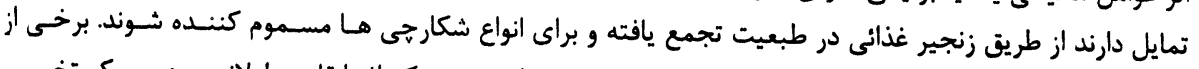

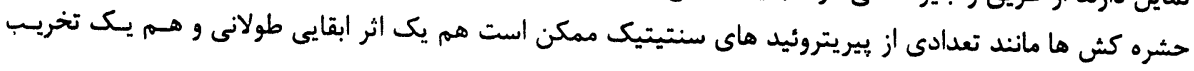
حيات نسبتا بالا را همزمان با هم داشته باشند.

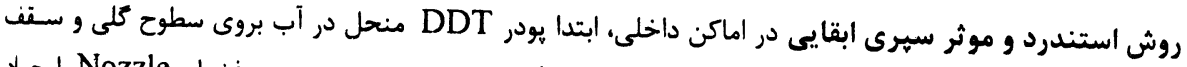

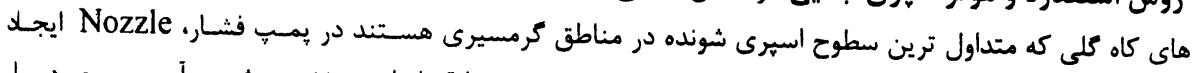

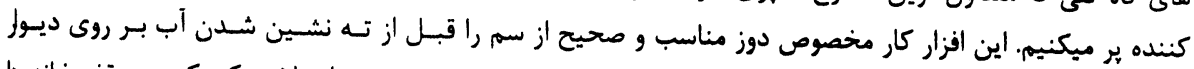

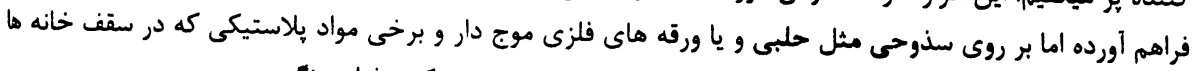

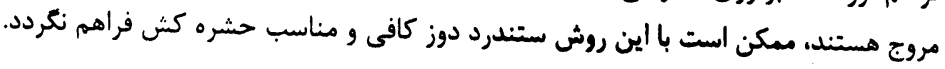




\section{WHO/MAL/98.1084}

\section{صفه Y}

براى كميهاى كاركران و آواره كان كه اغلب در خطر ايبديمى ملاريا قراز دارند به دليل استفاده از خيمـه هـا و شـيت

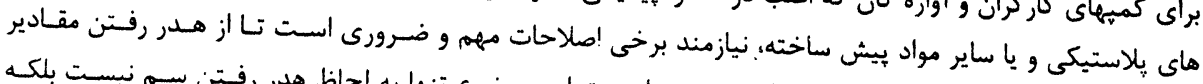

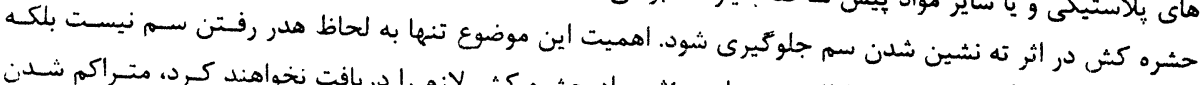

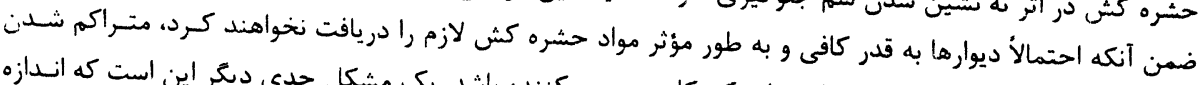

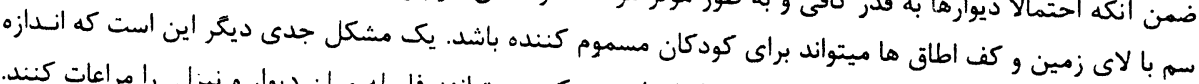

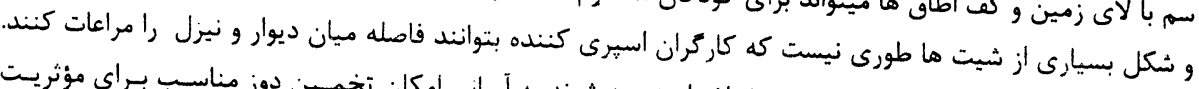

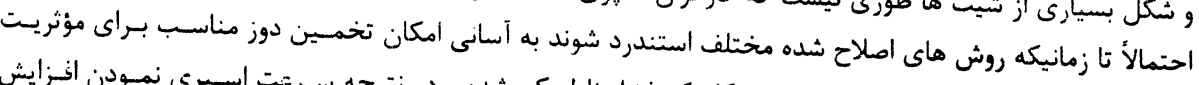

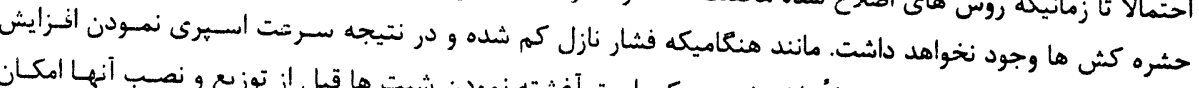

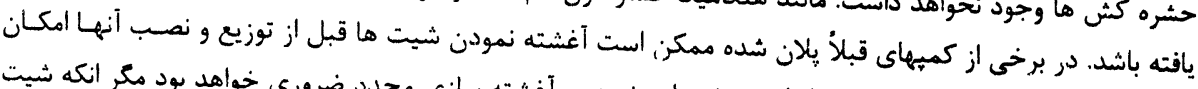

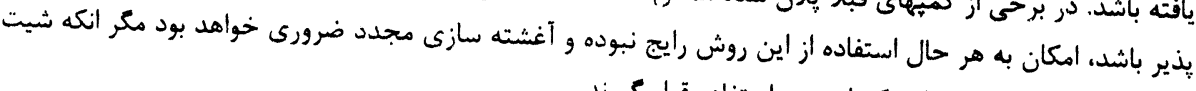
ها فقط براى دوره هاى زمانى كوتاه مورد استفاده قرار كيرند.

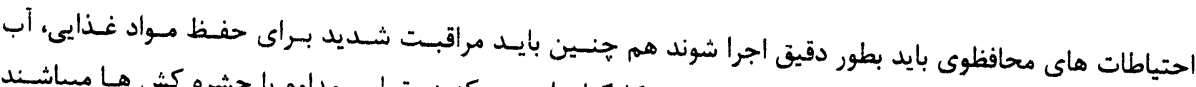

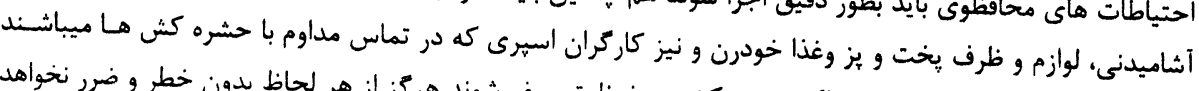

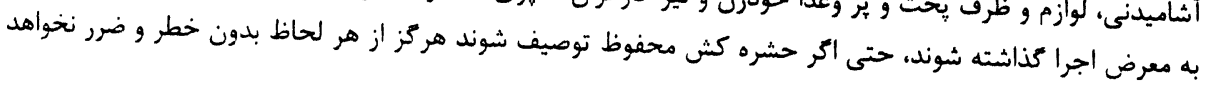

در انتخاب حشره كش ها بايد در دسترس بودن ذخيره و يذيرش جامعه و هم جنين مؤثريست مـورد انتظـار در محسل

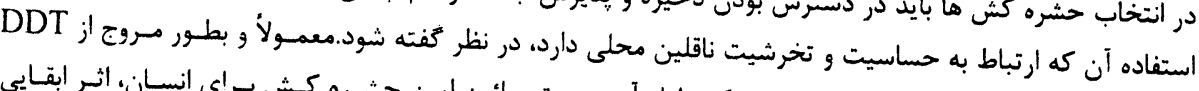

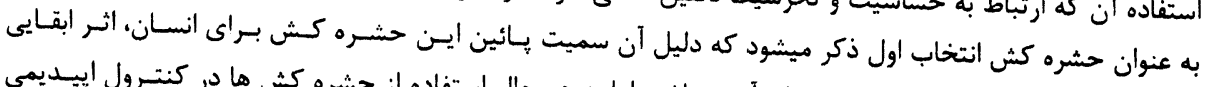

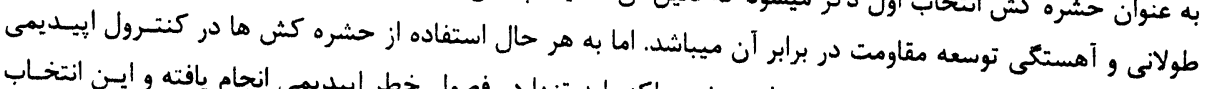

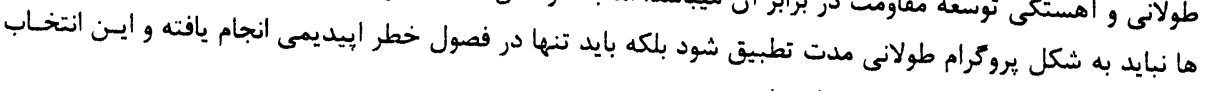
بر مبناى حساسيت جارى ناقلين منطقه باشد.

باقيماندن مدت طولانى DDT در محيط، استفاده از آنرا در اماكن خارجى دجار مشكلات ساخته حتى از خانسه هـاى

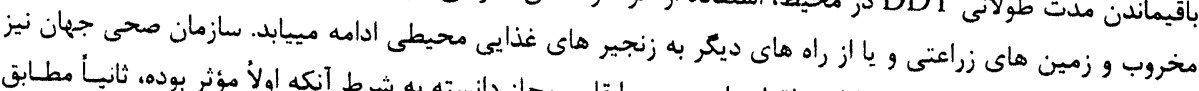

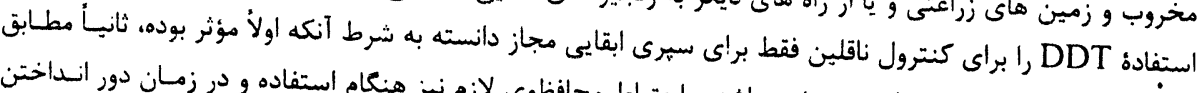

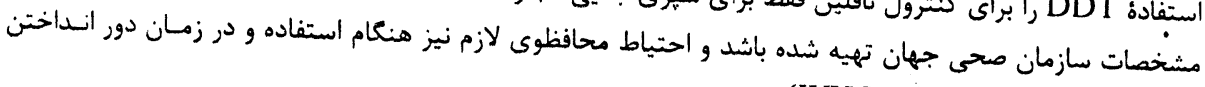
آن به كار كرفته شود (WHO, 1990).

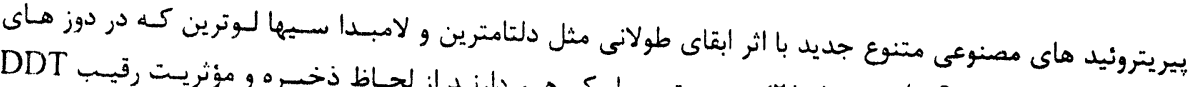

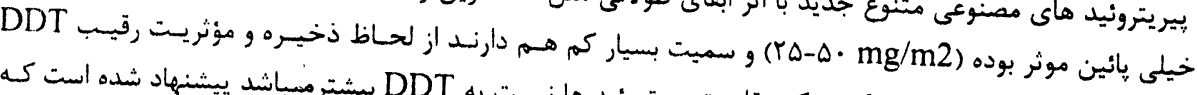

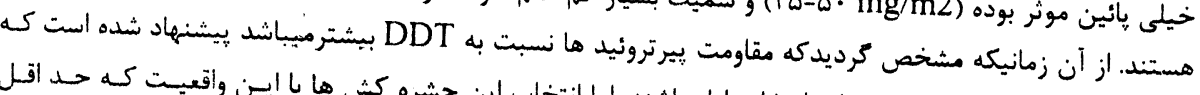

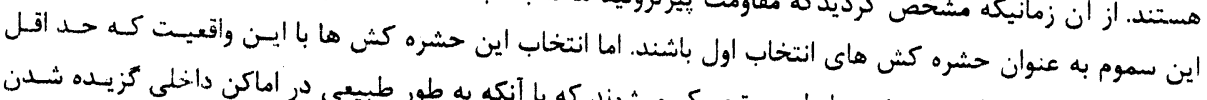

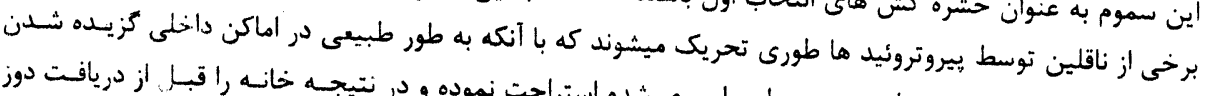

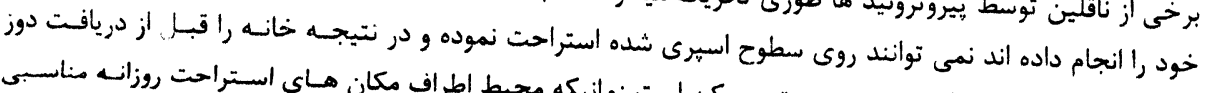

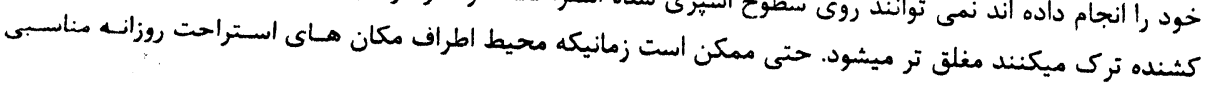




\section{WHO/MAL/98.1084}

\section{rA صفק}

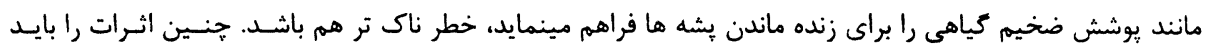

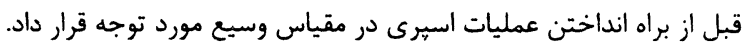

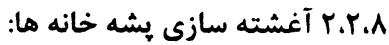

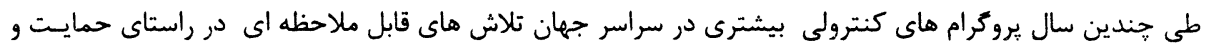

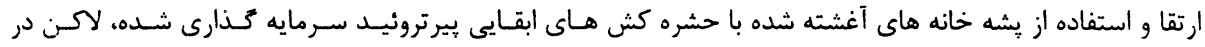

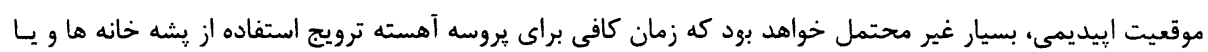

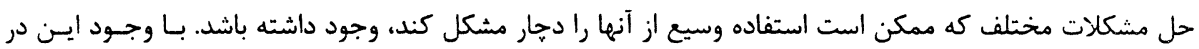

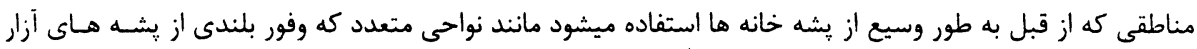

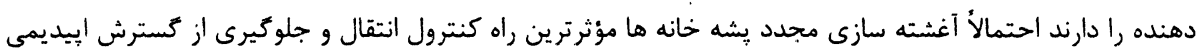

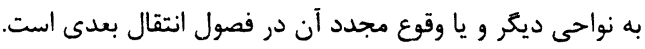

به طور عملى بيرتروئيد هاى مصنوعى يا سنتيتيك جديد به دليل مخاطرات كم و اثرات ابقايى مناسب بهترين حشـره .

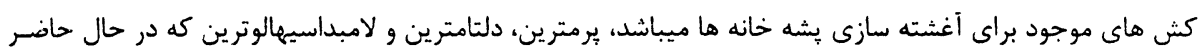

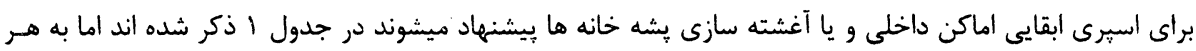

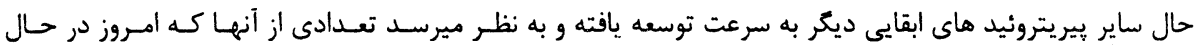

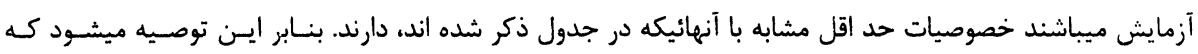

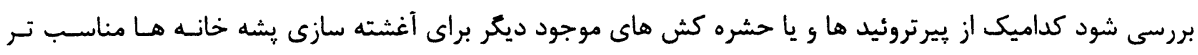




\section{سرويلانس إيبديمولوزيك، بيش بينى و وقايه از ابيديمى ها .III}

\section{EPIDEMIOLOGICAL SURVEILLANCE, FORCASTING AND PREVENTION OFEPIDEMICS}

9 9. سيستم هاى اطلاعات اييديميولوزى (Epidemiological Information Systems):

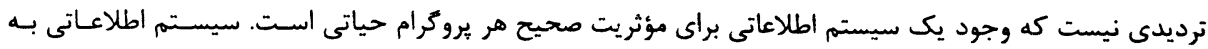

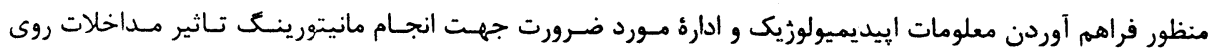

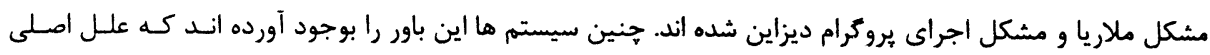

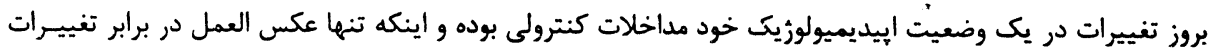

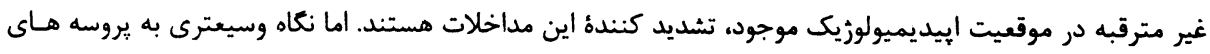

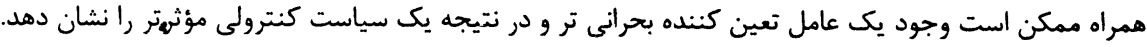

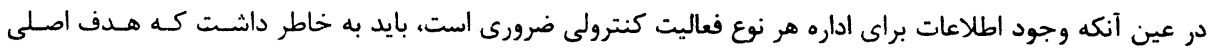

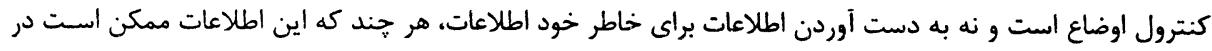

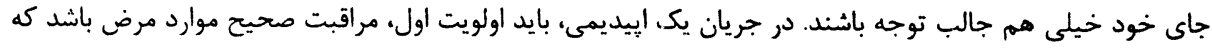

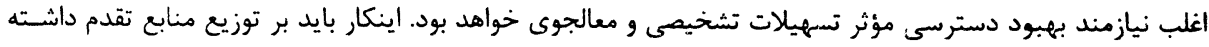

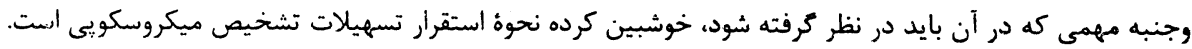
در حال حاضر اكثر يروكرام هاى مبارزه با ملاريا در دنيا در حال سازماندهى مجدد سيسـتم هـاى اطلاعـاتى خـود در

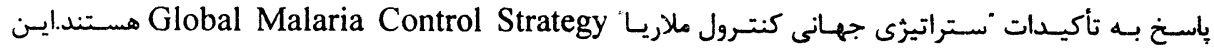

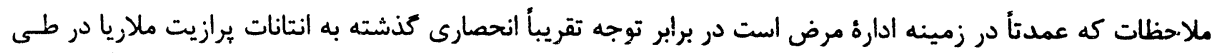

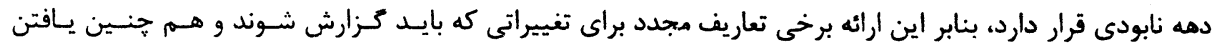

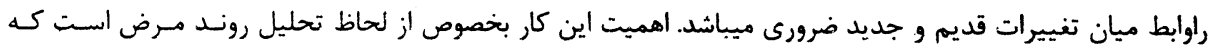

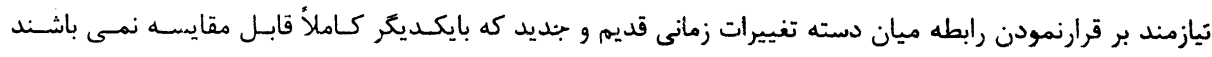

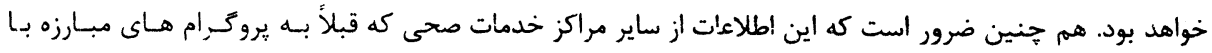
ملاريا كذارش نمى دادنا. نيز جمع آورى شود.

تأكيد جديد در زمينه ادارة مرض، نيازمند مانيتورينگ جداكانه ملاريا از نظر سريرى يا كلينيكى، واقعـات تائيـد شـده

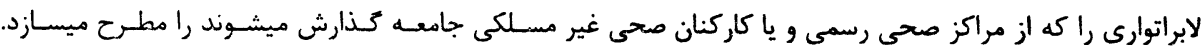

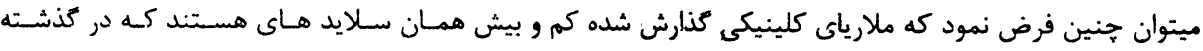

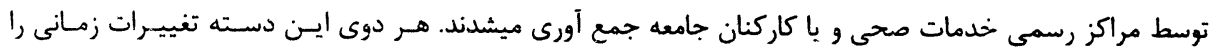

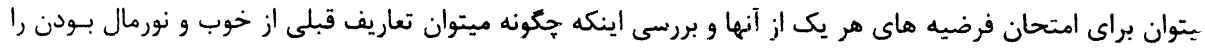

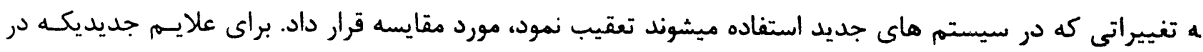

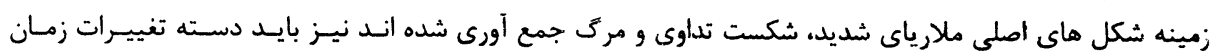
جديدى را شروع نمود.

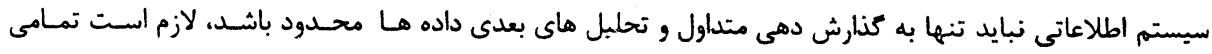

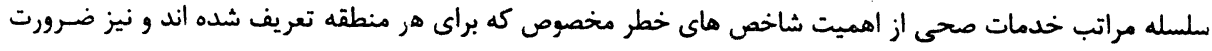

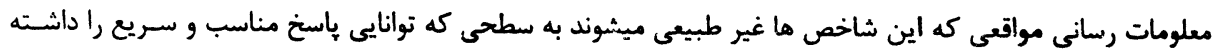




\section{WHO/MAL/98.1084}

\section{صغه .}

باشد، آكاه باشند. آنكاه بايد تحليل هاى جارى اطلاعات و روند ها از طريق انجام بررسى هاى صحيح بروتـرام شـده و

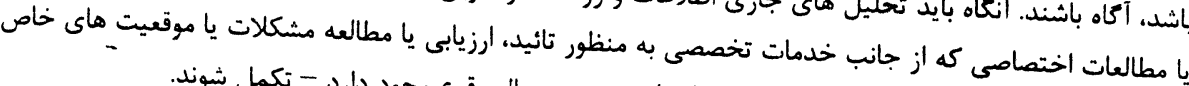

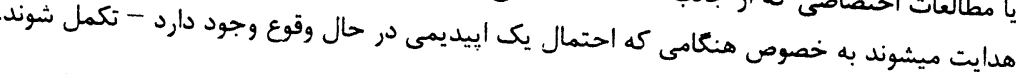

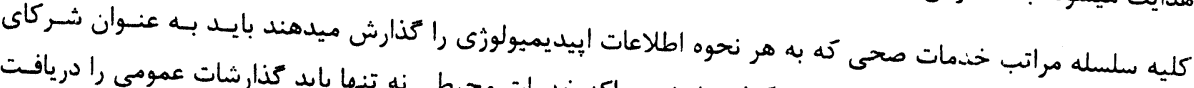

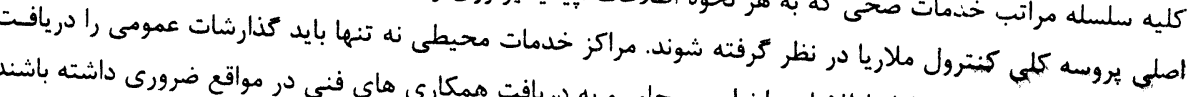

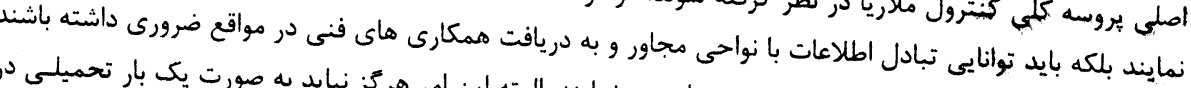

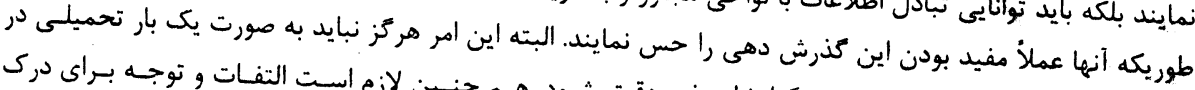

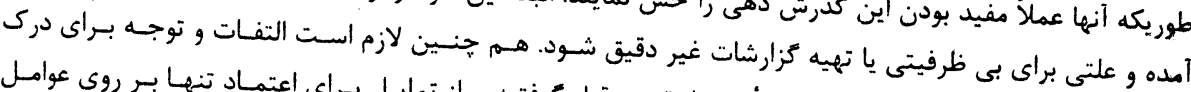

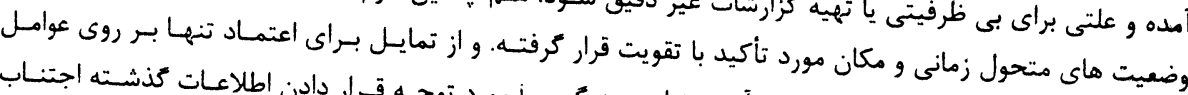

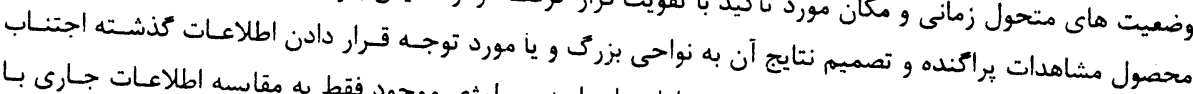

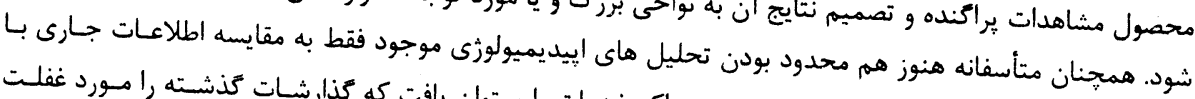

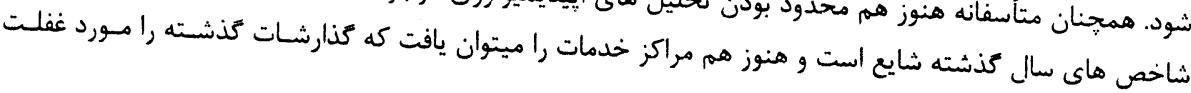

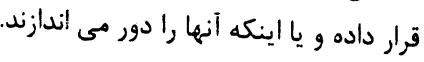

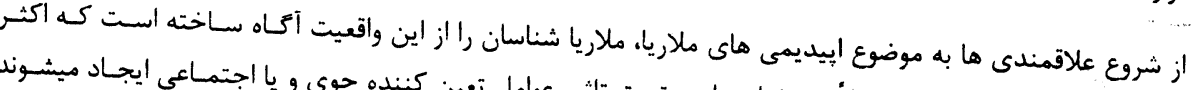

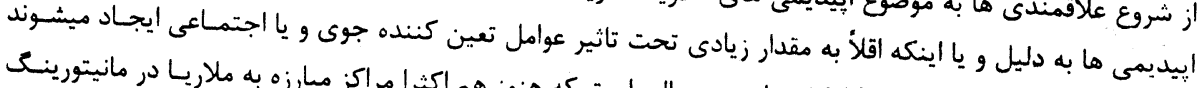

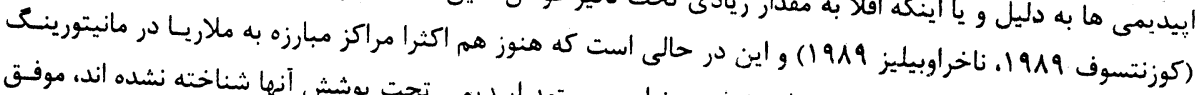

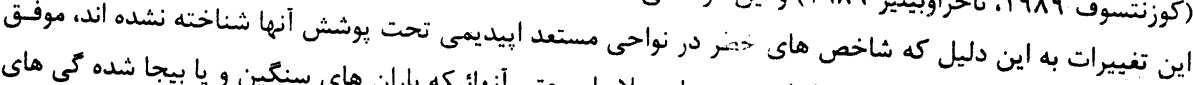

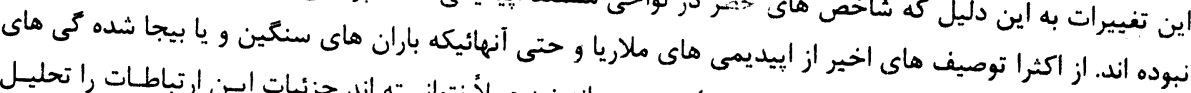

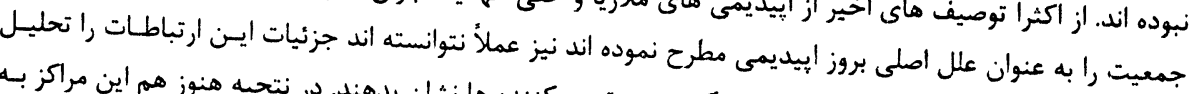

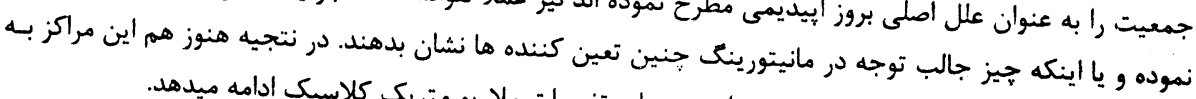
ايجاد سيستم هاى به اصطلاح هشدار دهنده اي برمبناى تغييرات ملاريو متريك كلاسيك الدين ادامه ميدهد.

دانستن اين موضوع كه خطر إيديمى هاى ملاريا در بيشتر موارد به وسيله تغييرات ايكولوزيكى و يا اجتمـاعى تعسين

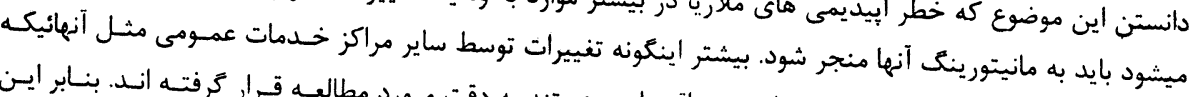

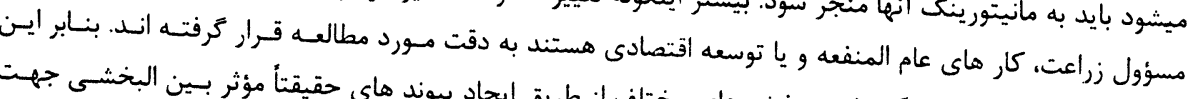

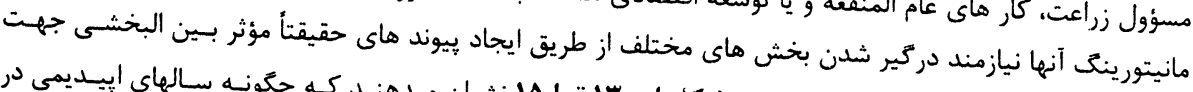

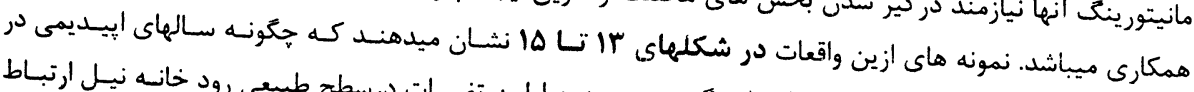

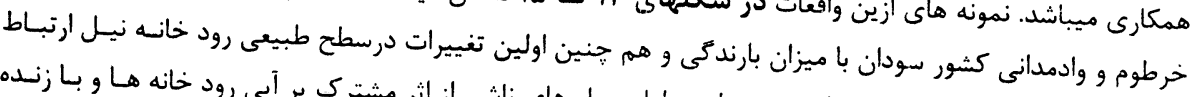

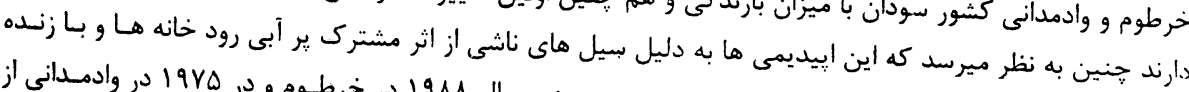

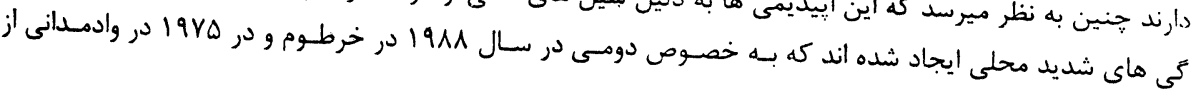

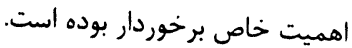

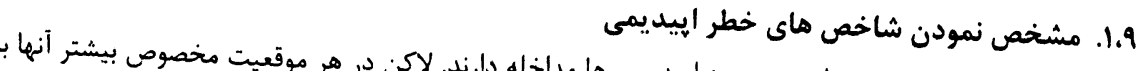

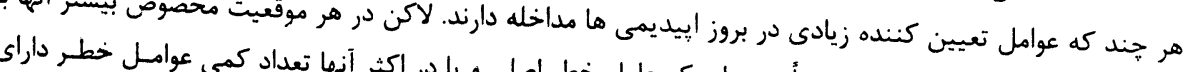

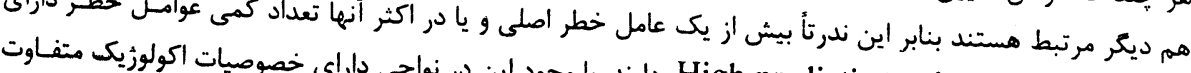

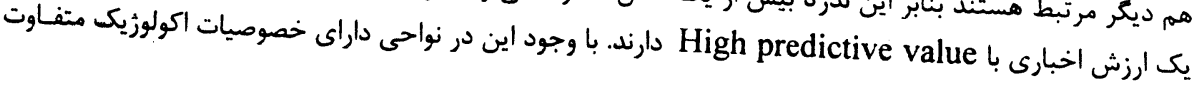




\section{V'HO/MAL/98.1084}

\section{صفحس I)}

و مجزا مانند دره هاى مرتفع و يا مناطق كه توسعه اقتصادى و اجتماعى بسيار متمركز دارند ممكن است تفاوت هـاى

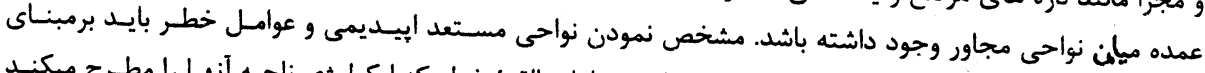

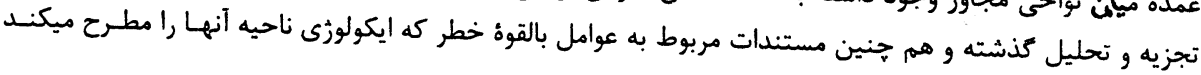
بايه كذارى شود.

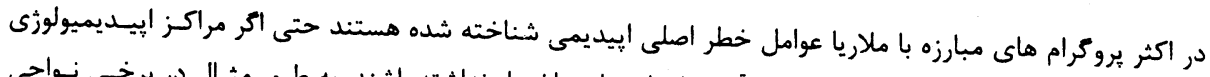

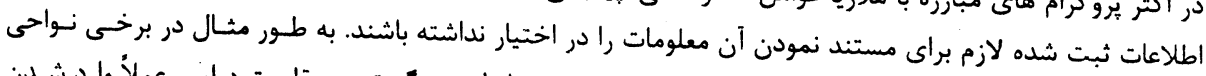

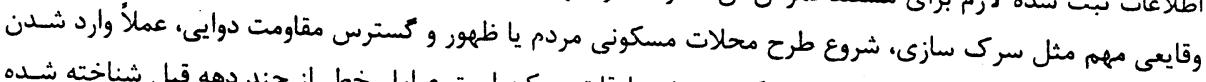

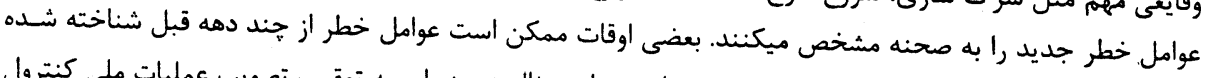

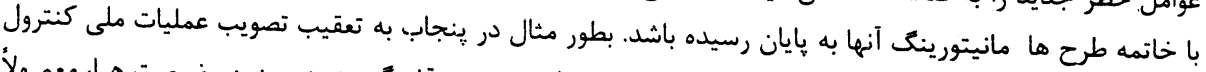

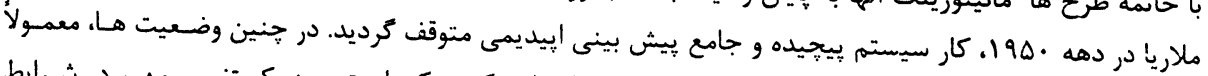

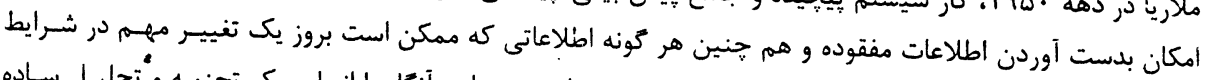

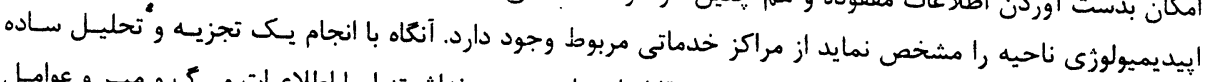

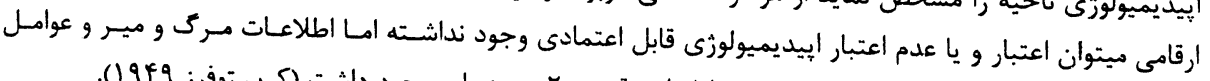

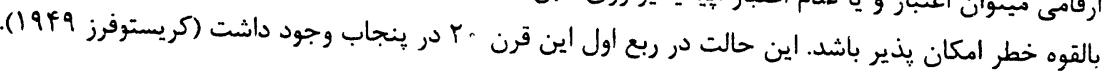
در نواحى ديكر ممكن است اطلاعات ثبت شده إيديميولوزى وجود نداشته باشد اما مراكز هوا شناسى ثبت تفصيلى

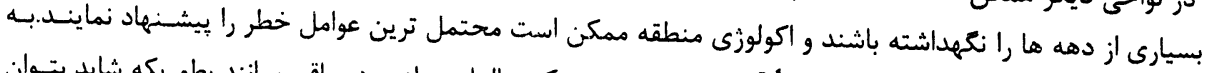

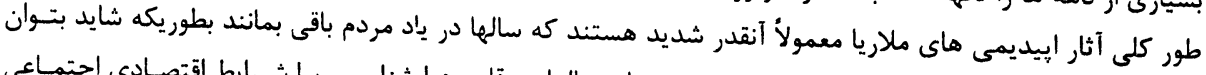

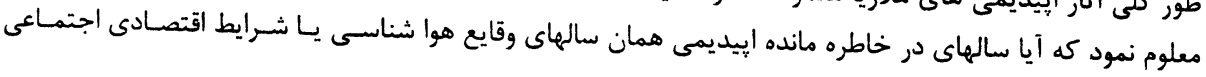

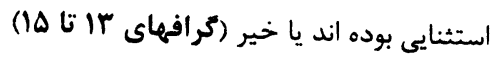

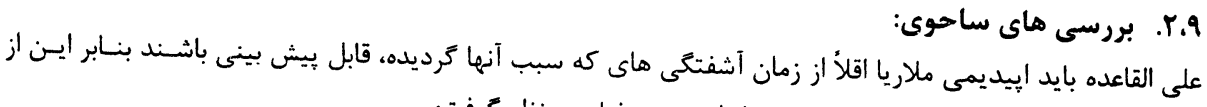

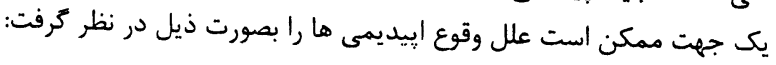

عدم موفقيت در درك إيديميولوزى محلى مرض به خصوص روابط تعاملى ميان بروسـه هـاى ايكولوزيـك و

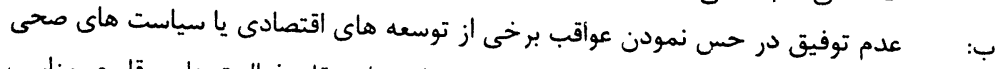

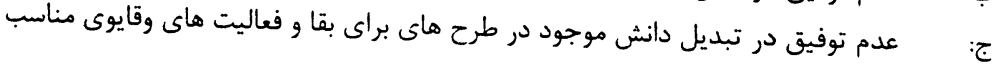

وقوع هر إيديمى فرصتى را براى دريافت دانش ايبديميولوزى موجود فراهم مى آورد و تغييرات و تحولات محسنوديت

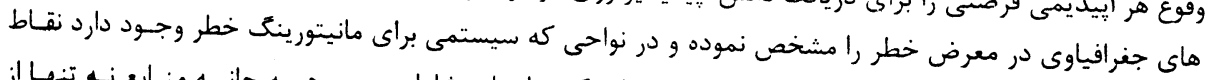

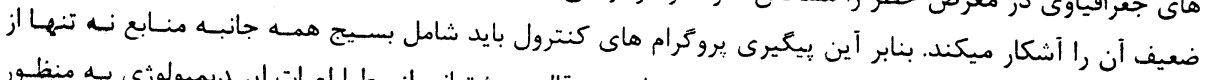

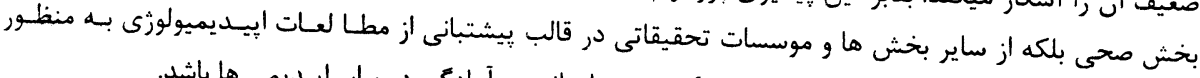

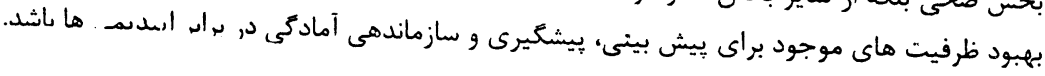




\section{WHO/MAL/98.1084}

صنح Y P

كراف rا تغييرات سطح آب رود خانه نيل در خرطوم (سير طبيعى •199 (19Y)

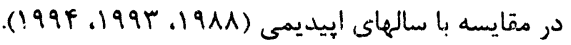

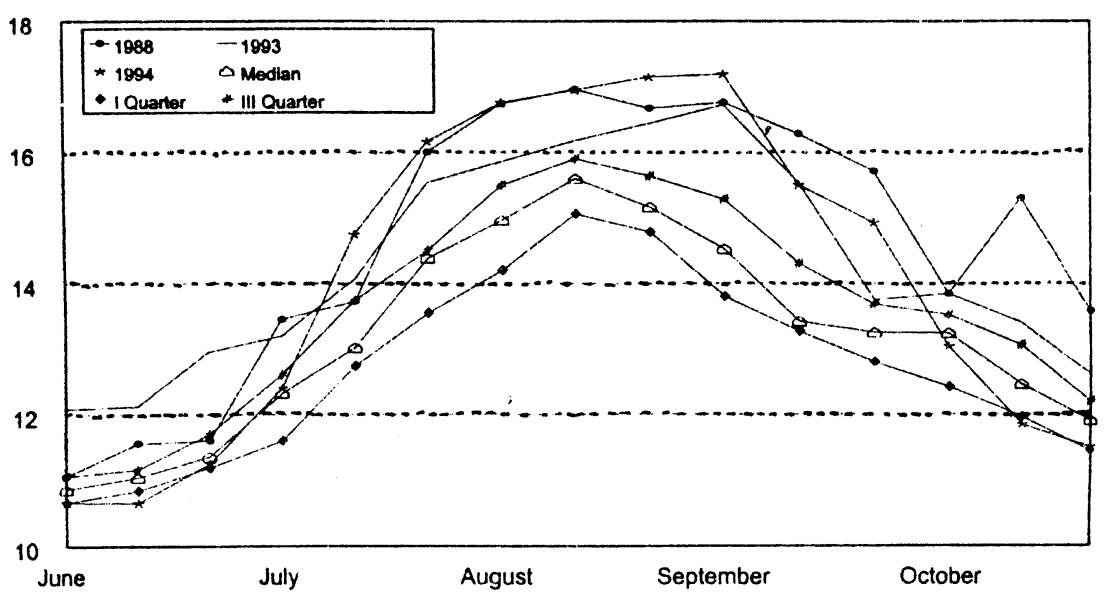

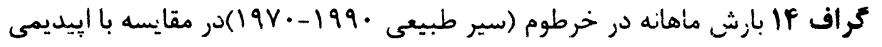

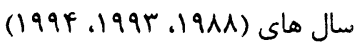

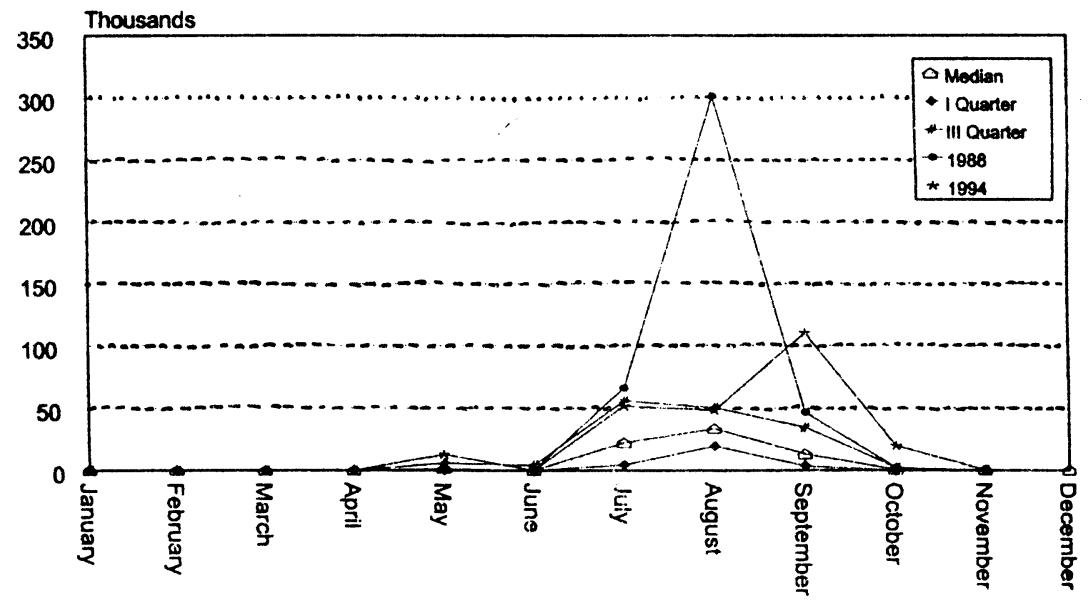




\section{WHO/MAL/98.1084}

صفحه

شكل ها تغييرات سطح آب رود خانه نيل در وأدمانى (سير طبيعى •199 -1997)

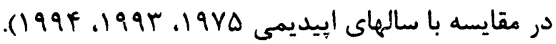

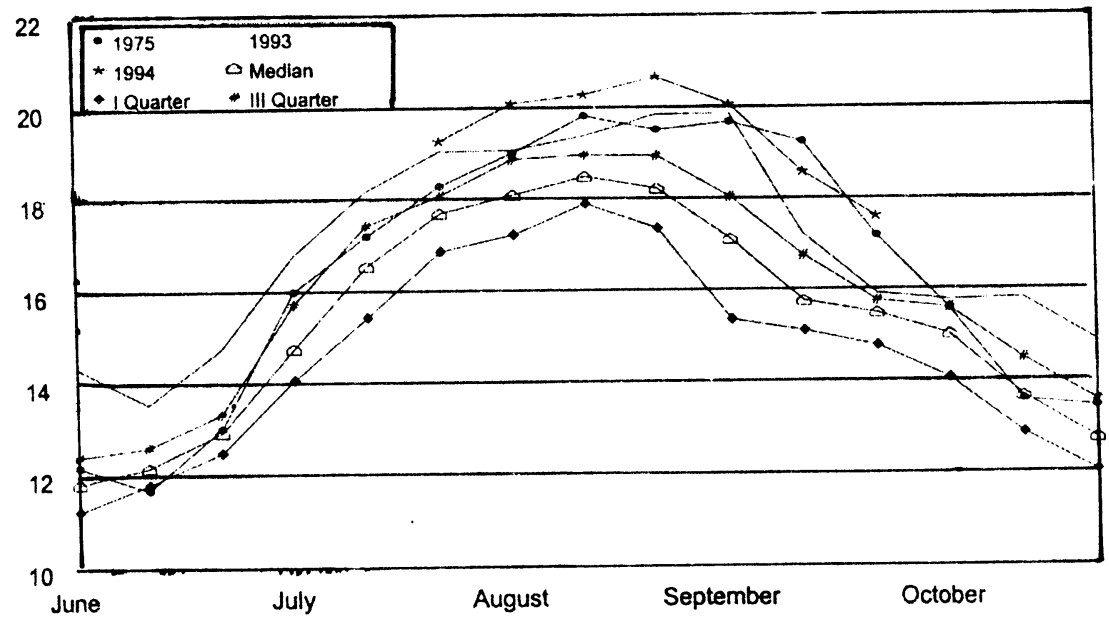

شناختن يكى ناحيه به عنوان ناحيه ايكه در معرض كروب خاص از عوامل خطر إيـديمى قـرار دارد، بعضى از عوامـل

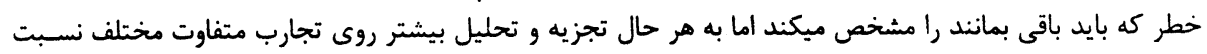

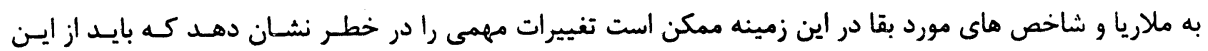

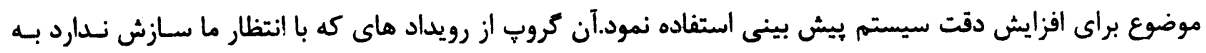

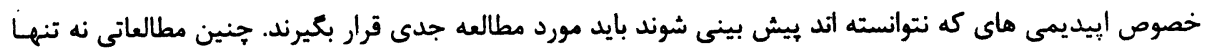

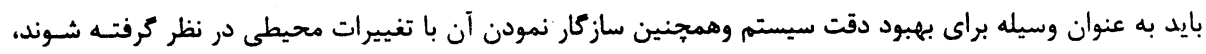

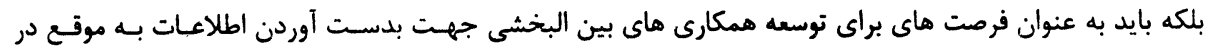

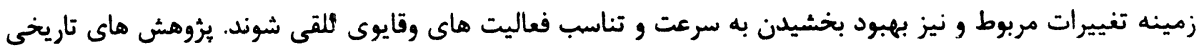

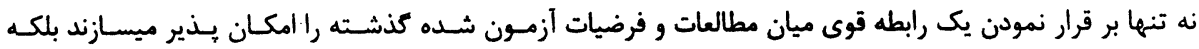

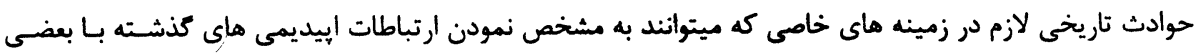

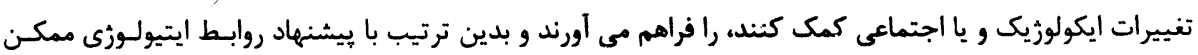
نقش ارزنده را در جستجوى شاخص ماى مفيد خطر إيديمى بازى ميكنئد

هم جنين مطالعه إيديمى هاى واقعى و مقايسه نافلين اصلى يك ناحيه ممكن است اهميت برخى از ناقلين ديكـر در

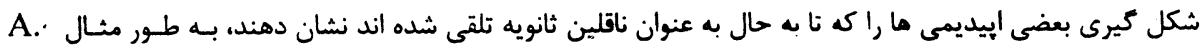
واري و Annularis

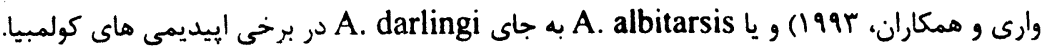

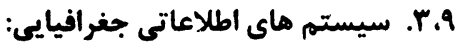

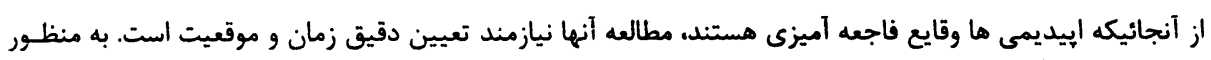

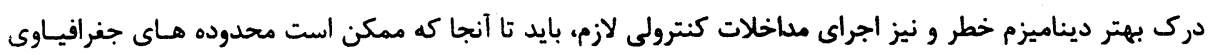




\section{WHO/MAL/98.1084}

\section{صنحن \&}

هر بديده به طور دقيق تعريف كردد. اكثر كشور ها نقشه هاى تويوكرافى و سياسى خوبى دارند كه خصوصسيات مهـم

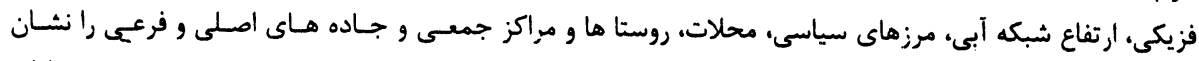

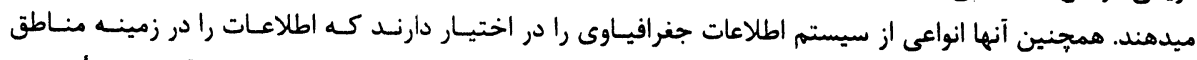

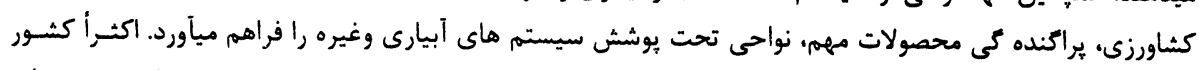

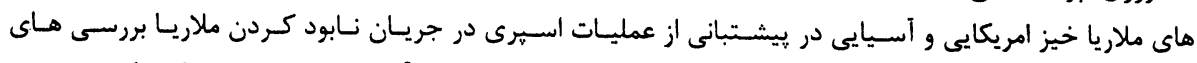

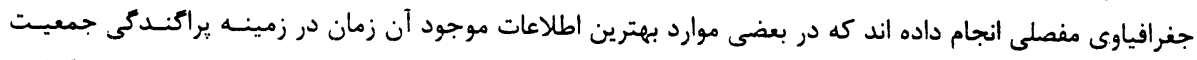

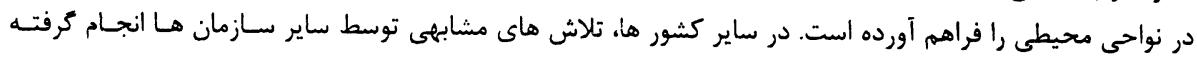

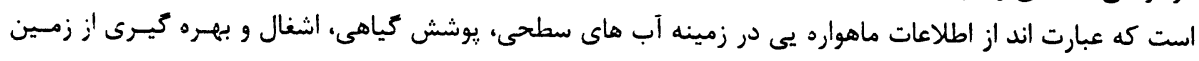

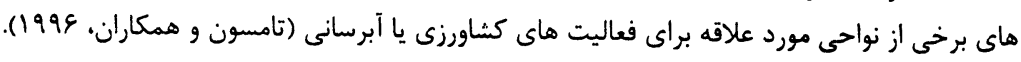

نوآورى هاى مخابرات و كمييوتر وسيله هاى اقتصادى و مؤثرى برأى ايجاد يـك سيسـتم يويساى اطلاعـاتى ميباشـند.

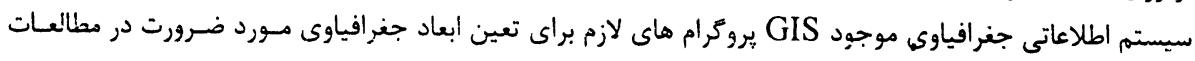

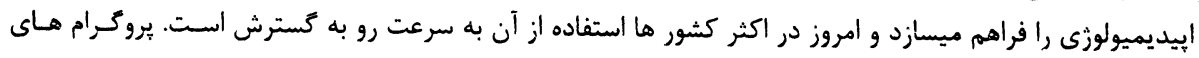

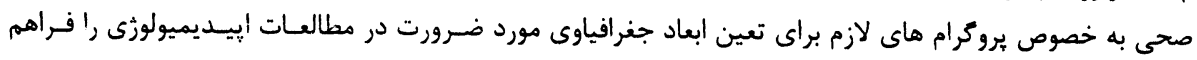

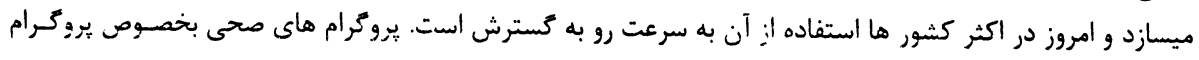

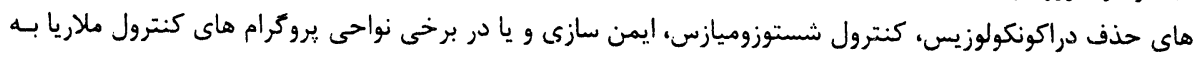

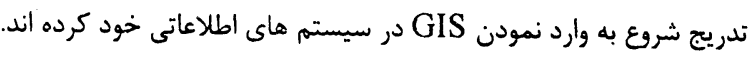

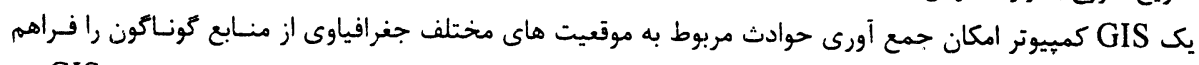

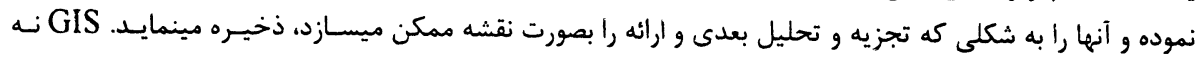

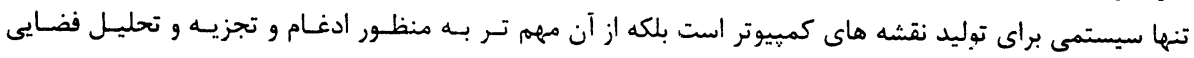

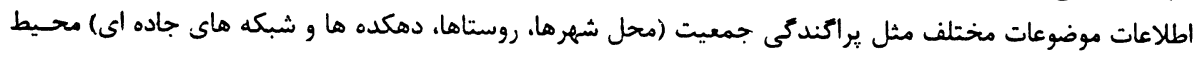

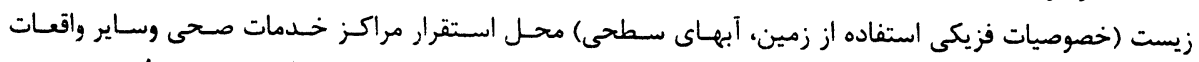

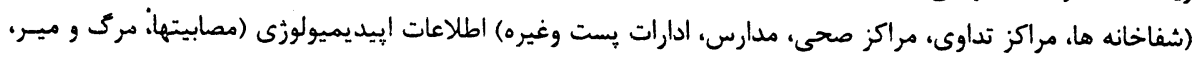

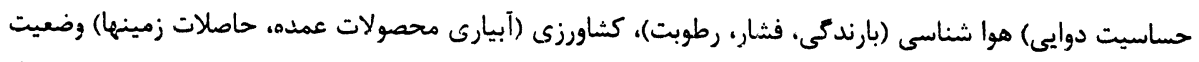

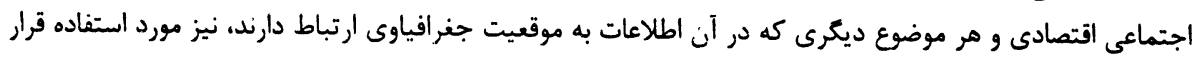

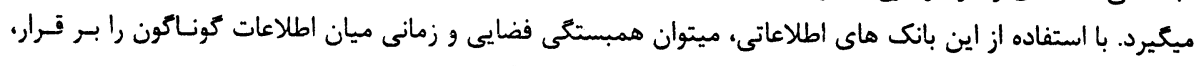

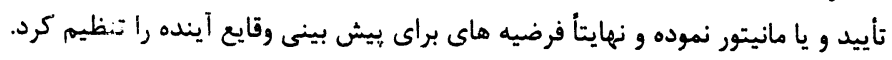

مطالعه يتانسيل إيديمى بايد به بهترين وجه امكان از منابع موجود براى GIS را فراهم و در جايى كه جنين منسابعى

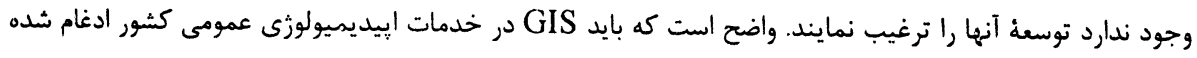

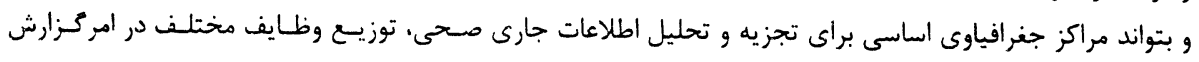

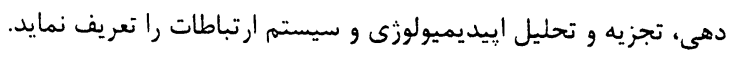

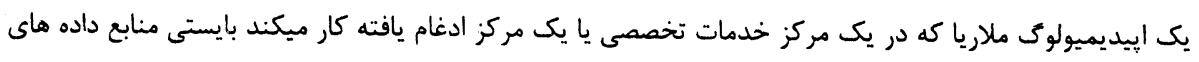

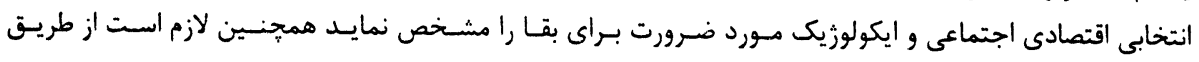

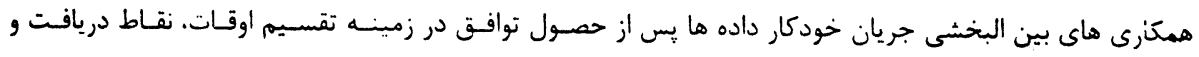




\section{WHO/MAL/98.1084}

\section{صغه}

همجينين كار برد و توزيع آنها تأمين كردد. تقويت و توسعة GIS براى وقايه و كنتـرول اييـديمى هـا نيازمنـد منسابع

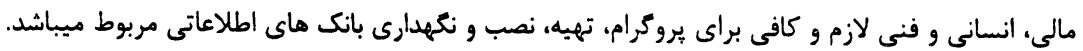

\section{•ا. تشخيص خطر و بيش بينى إييديمى (Risk detection and forcasting):}

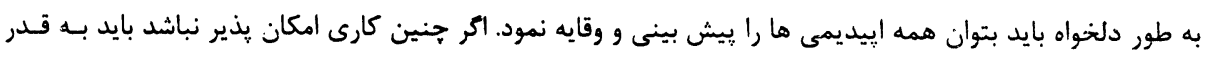

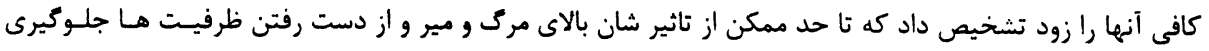

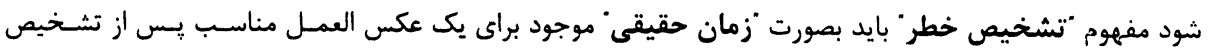
خطر قريب الوقوع بيان شود.

بخصوص مهمم است كه در يك إيديمى جديد بتوانيم نشيب بالقوه موج نخستن إيديمى و هم هنين ناحيه احتمـالى

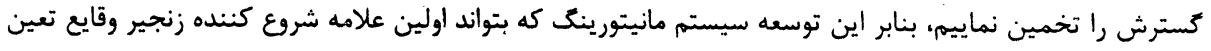

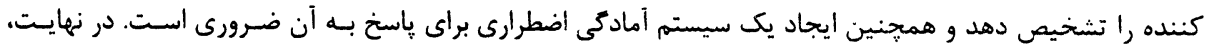

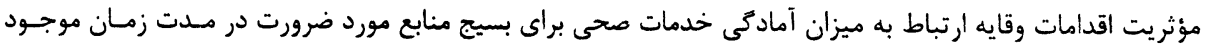

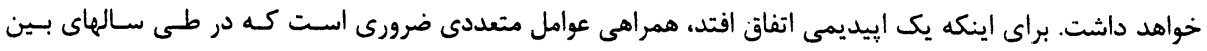

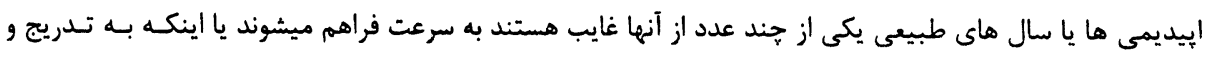

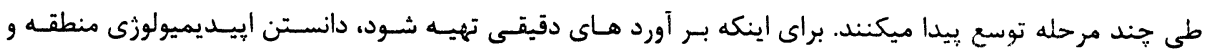

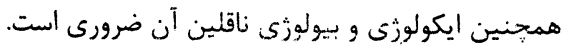

از اوايل دهه • له 19 به بعد كم كم علاقمندى به وقايه از اييديمى ها از بـين رفـت، زيسرا بـه تعقيـب اجـراى عمليـات

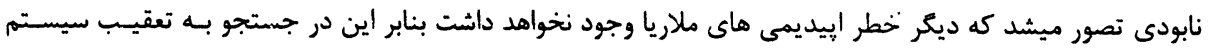

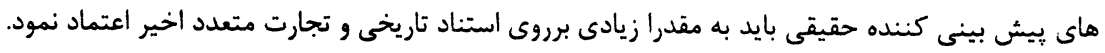

\section{Monitoring . 1.1.}

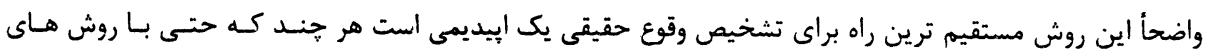

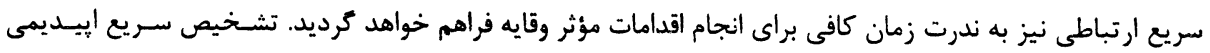

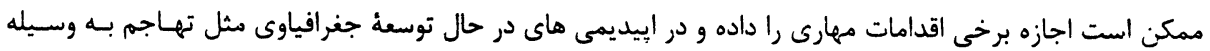

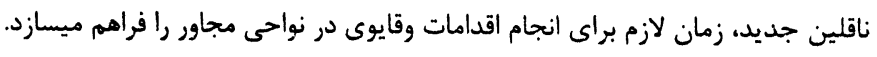

Monitoring واقعات ابتلا روش كلاسيك مراقبت هاى إيبديميولوزى است كه يكى از طريقـه هـاى اسـتندرد آن

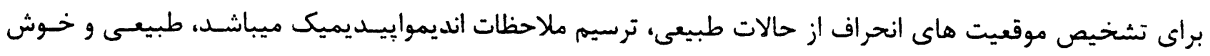

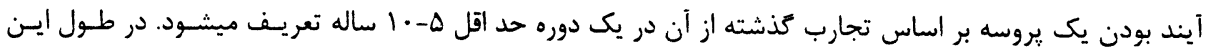

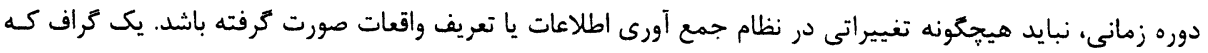

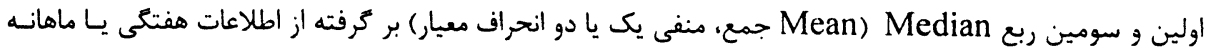

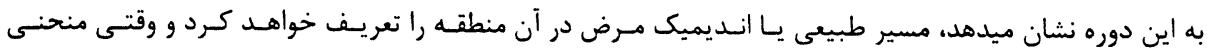

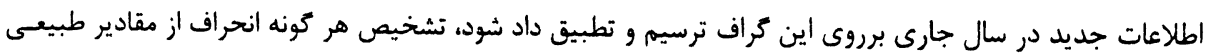

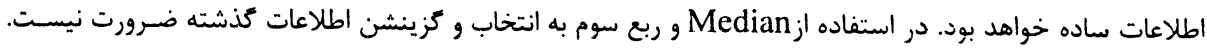

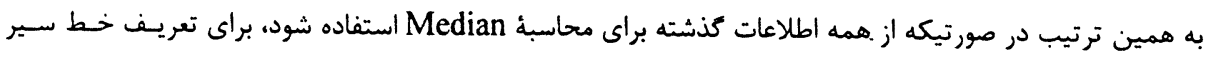




\section{صفحه}

طبيعى، فقط يك انحراف معيار مورد استفاده قرار ميكيرد لاكن هنكاميكه اطلاعات غير طبيعى حذف ميشوند، ترجيح

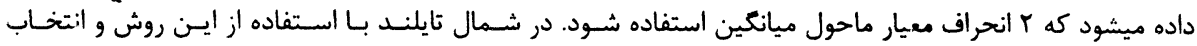

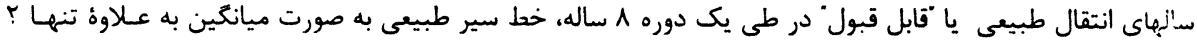

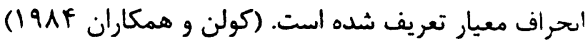

با وجود اين دوام واقعات ابتلا به مرض ملاريا به دليل روش هاى كند و يِجيجيده اى كه در اكثر مراكز مبارزه بـا ملاريـا

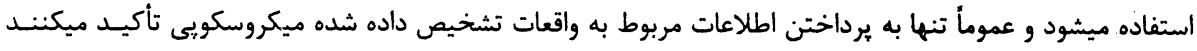

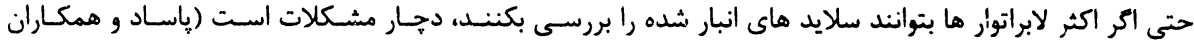

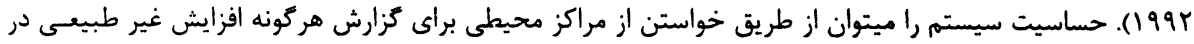

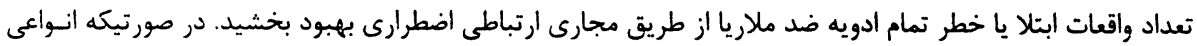

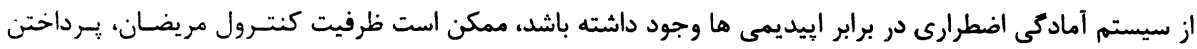

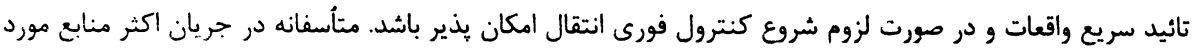

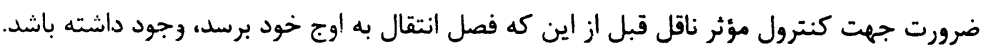

مطالعات كذشته مشاهده بر روى ارقام مرى و مير، كه عمومأ كاملتر و قابـل اعتمـاد تــ از تعـداد واقعـات ابـتلا

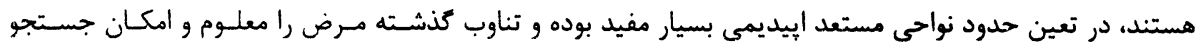

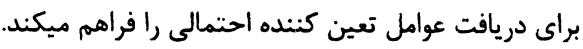

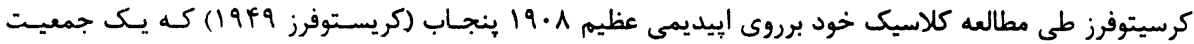

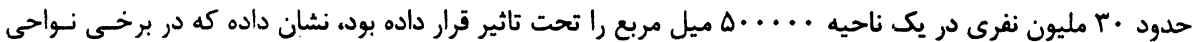

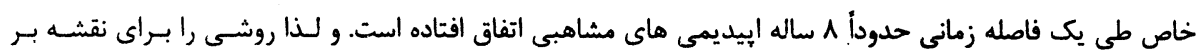

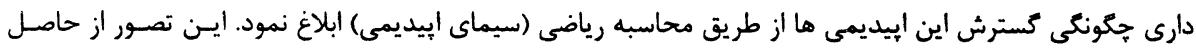

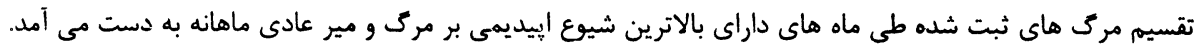

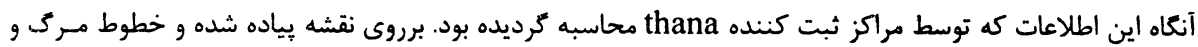

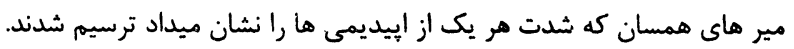

كميسيون ملل متحد در رابطه با ملاريا شاخصى را براى بتانسيل إييديمى ها بر اساس ضريب تغييرات مرك و ميسر

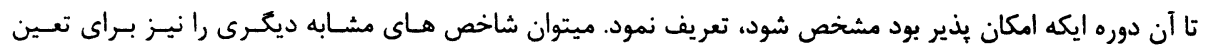

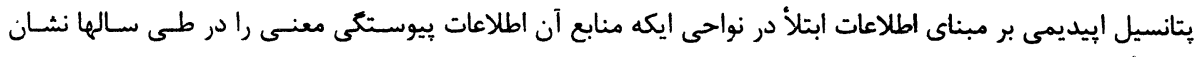
ميدهند، يِيريزى نمود.

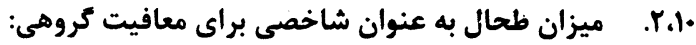

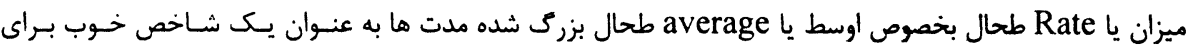

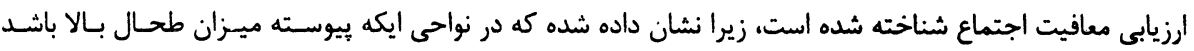

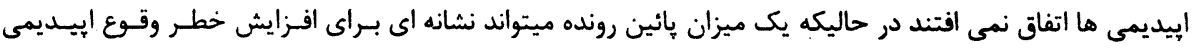




\section{WHO/MAL/98.1084}

\section{\& صفح}

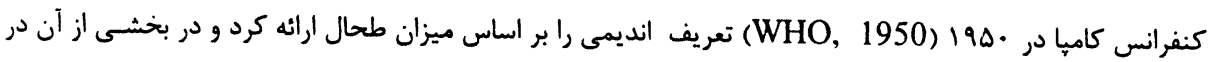

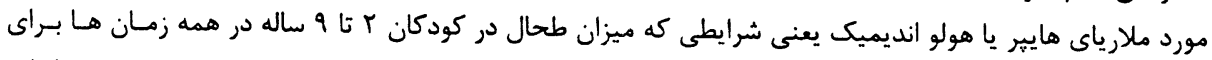

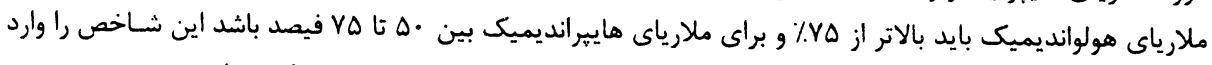

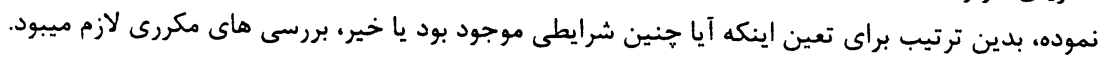

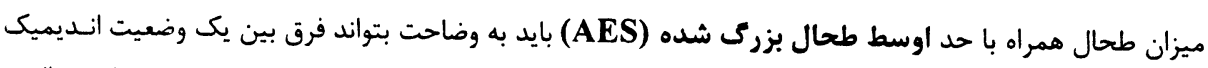

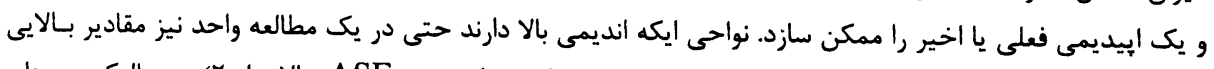

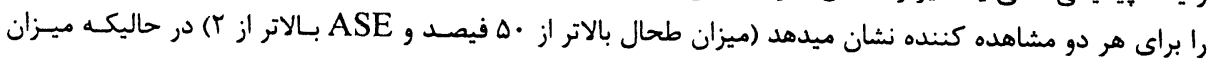

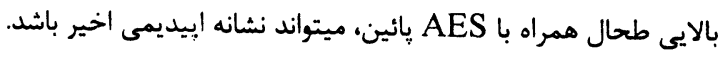

حتى اكر بزركى طحال در نواحى ايكه ادويه ضد ملاريا به مقدار وسيع استفاده ميشوند ارزش كلى خـود را بـه عنـوان

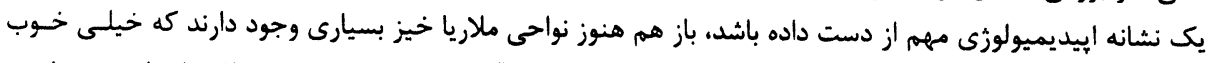

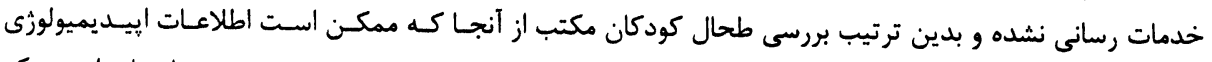

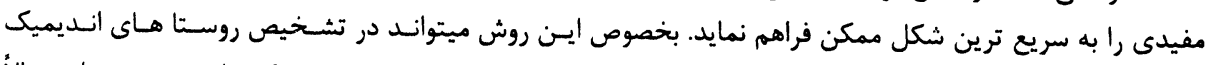

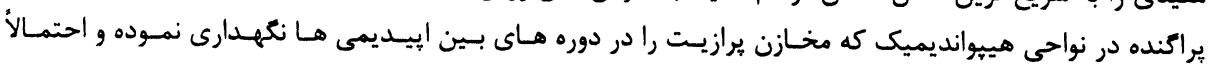

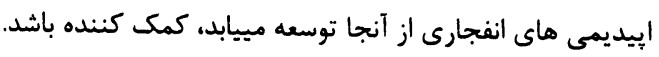

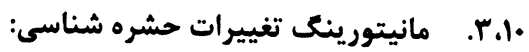

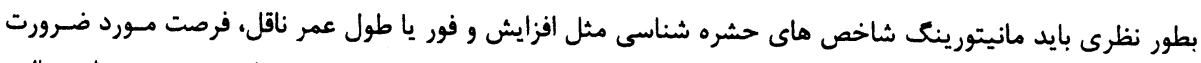

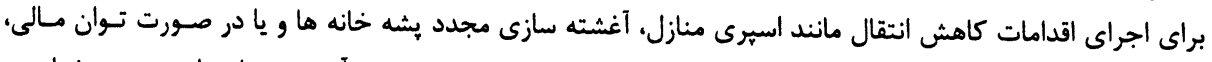

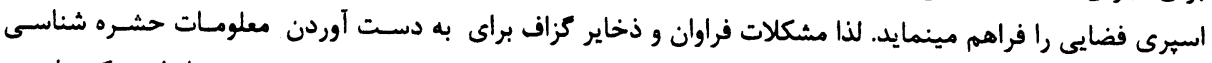

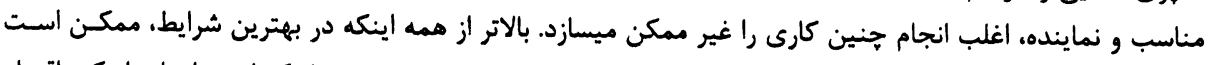

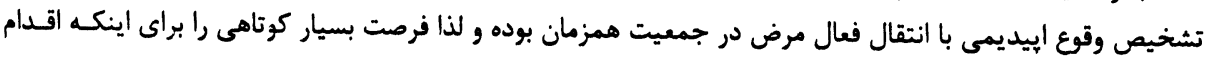
مؤثرى عليه آن برداشته شودو باقى كزارد.

يا ميزان تلقيع حشره شناسى به عنوان شاخص جامعى براى ارزيابى خطر ابيديمى بيشنهاد شده استـ كـه

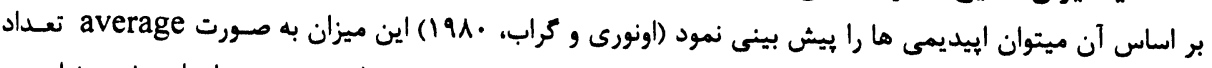

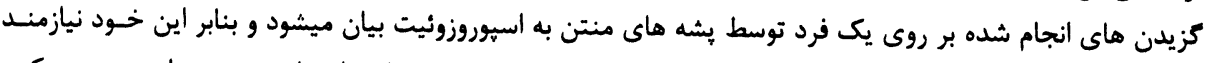

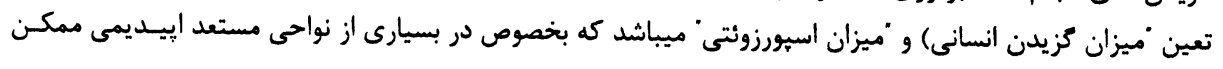

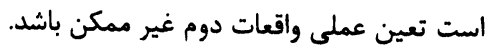

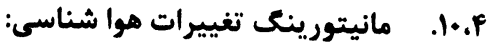

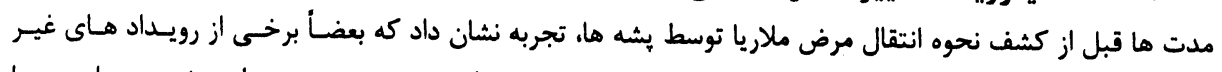

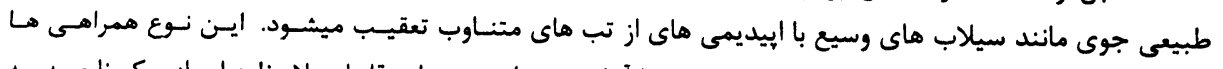

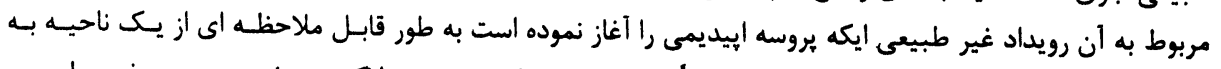

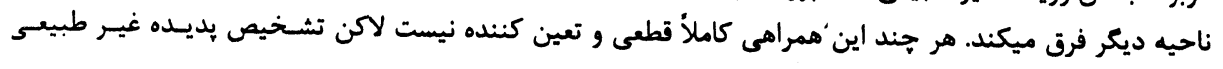




\section{WHO/MAL/98.1084}

\section{صفح 1 \&}

جوى معمولاً نسبتاً ساده بوده و لذا مورد خوبى از افزايش خطر ابيديمى را به دست خواهد داد. در دوام تغييـرات هـوا شناسى بايد تشخيص موارد ذيل مورد هدف قرار كيرد:

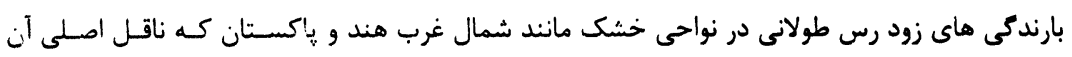

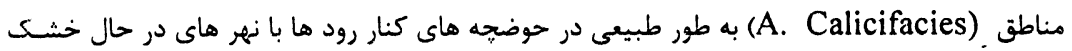

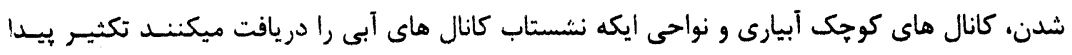

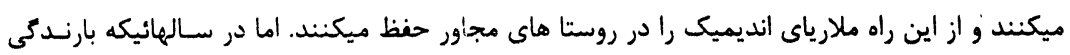

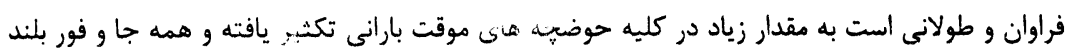

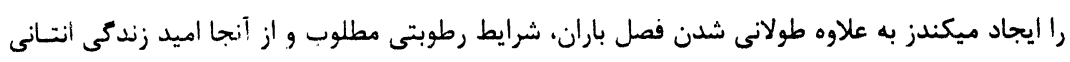

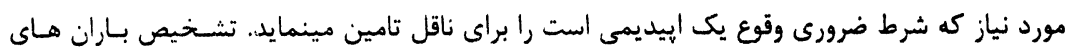

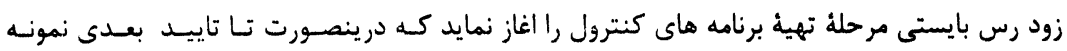

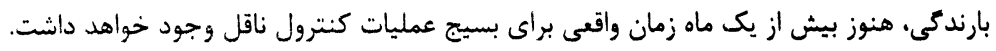

دوره هاى خشكسالى غير عادى در قسمت هاى مانند دره هاى با ارتفاع متو.سط در مناطق ميانسه (واقـع

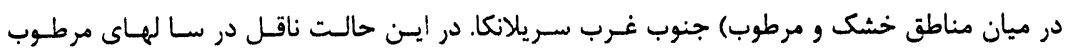

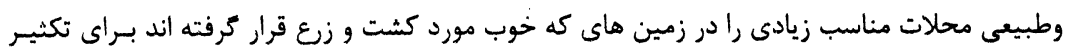

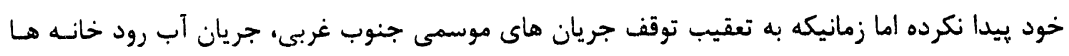

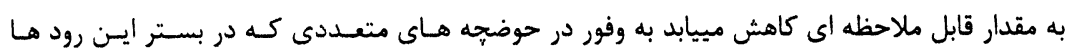

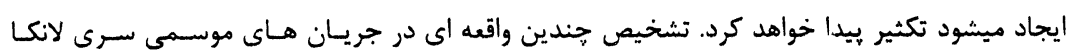

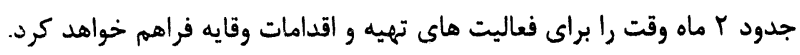

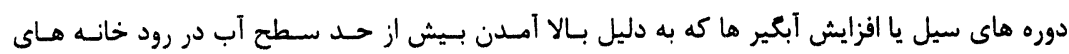

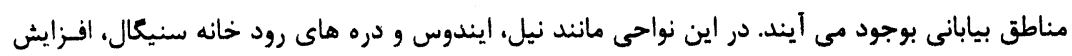

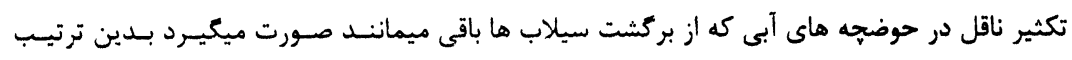

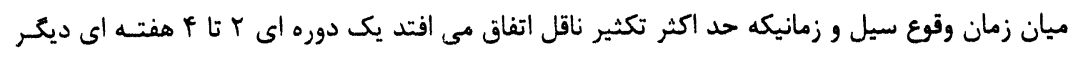

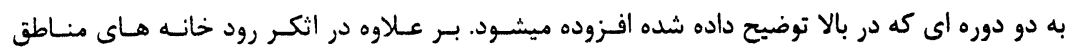

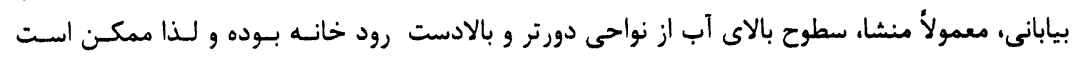

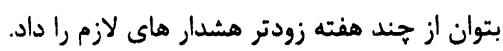

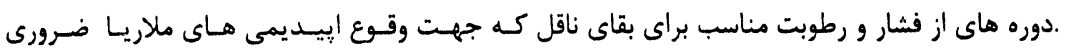

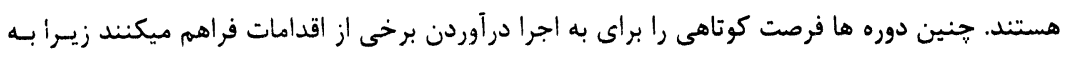

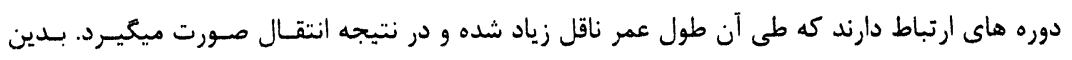

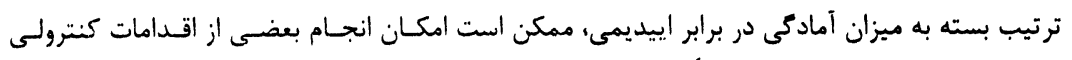

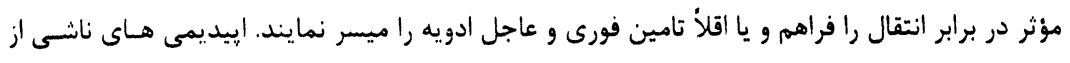

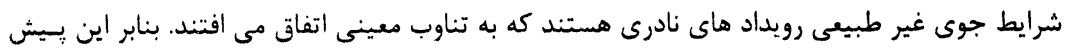

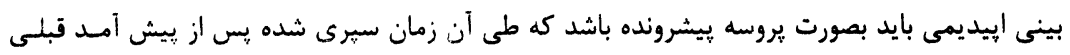

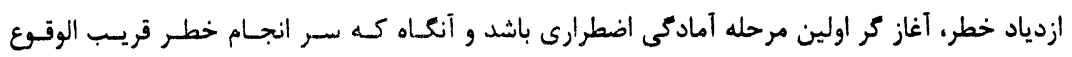




\section{WHO/MAL/98.1084}

\section{صفحس 9 9}

ايبديمى تائيد ميشود، بايد اولين اخطار از جانب سيستم مانيتورينك مـرض منجربـه تقويـت تسههيلات

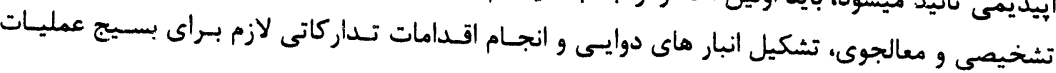
كنتروز ناقل كردد.

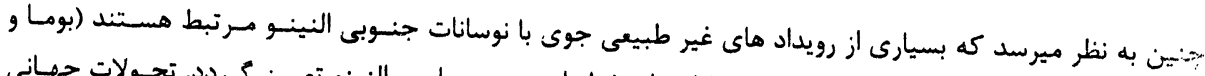

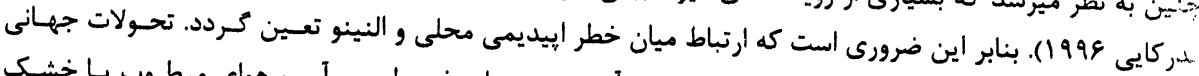

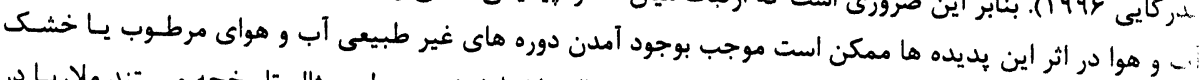

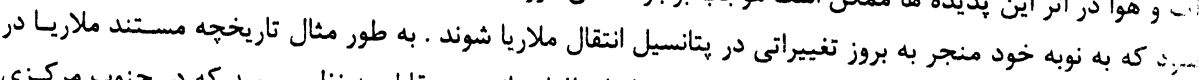

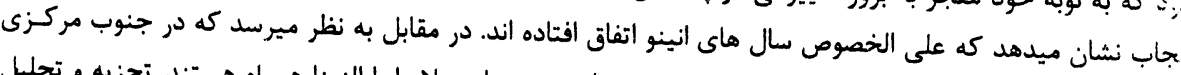

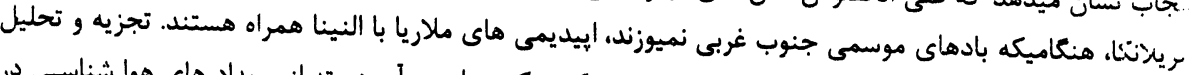

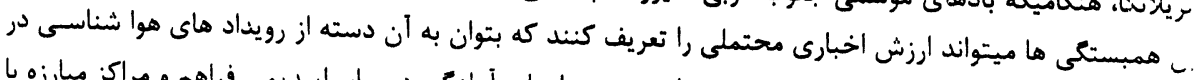

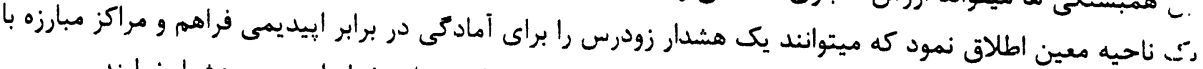
ملازيا را جهت تشديد فعاليت هاى بقا و كزارش دهى سريع شاخص هاى محلى خطر إيبديمى هشيار نمايند.

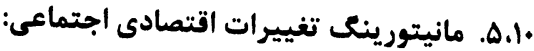

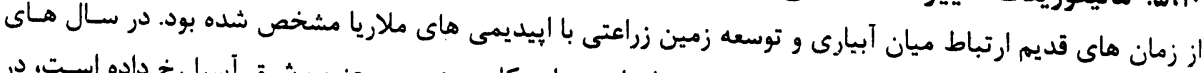

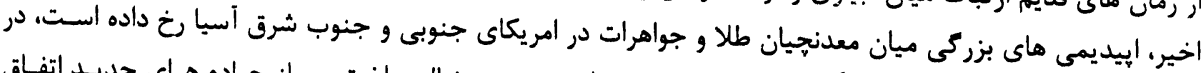

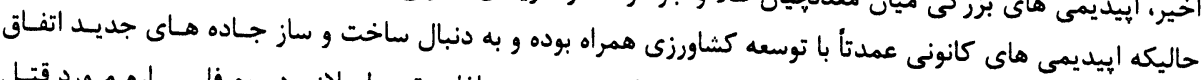

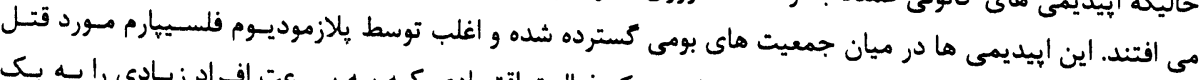

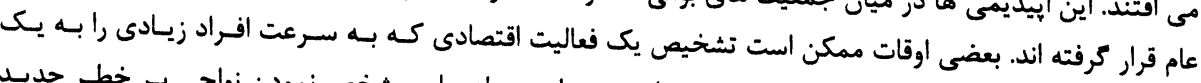

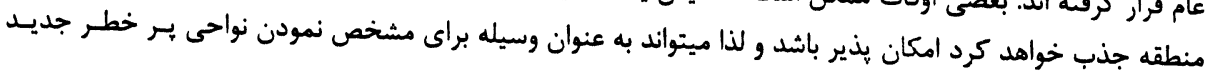

مورد منيتورينك قرار بكيرد به طور مثال:

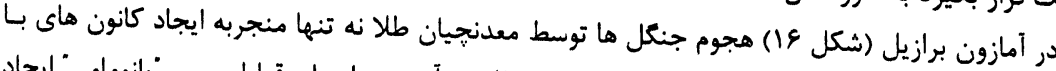

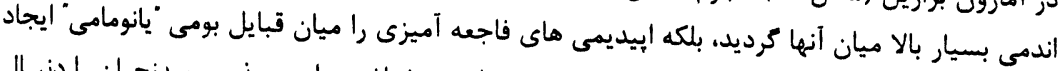

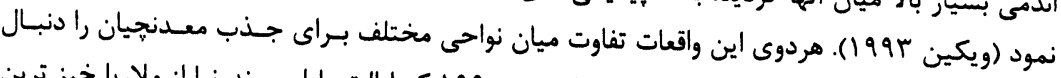

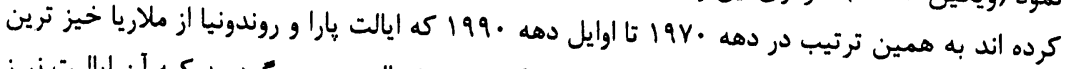

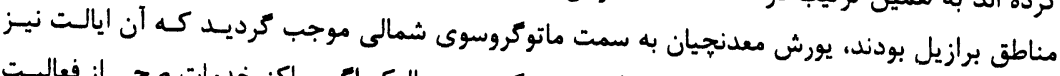

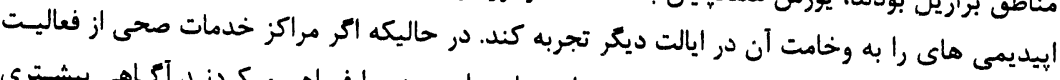

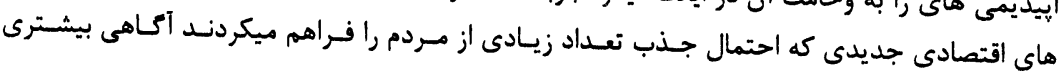

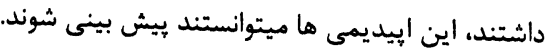


WHO/MAL/98.1084

صفحه .

كراف \&| واقعات كزارش شدة ملاريا در برازيل

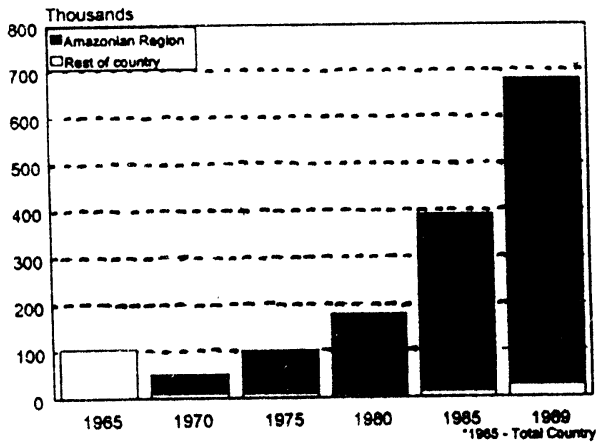

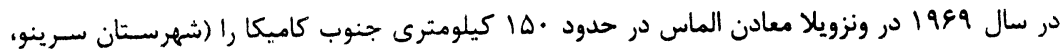

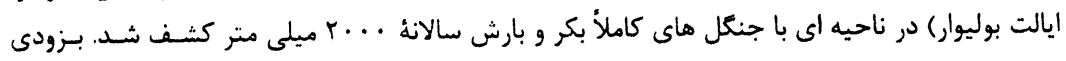

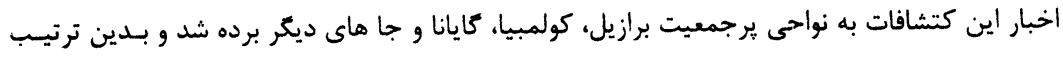

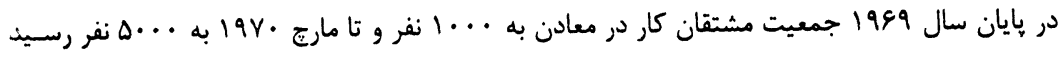

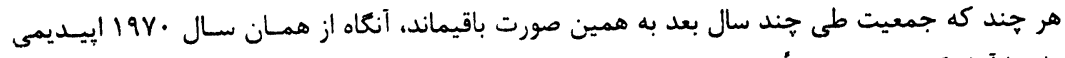

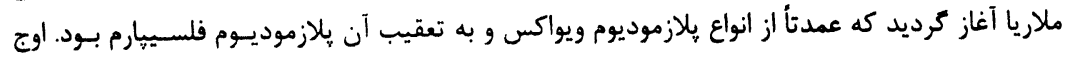

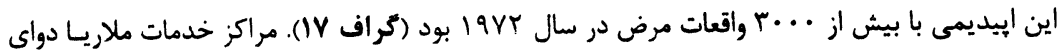

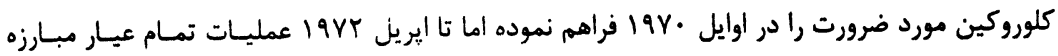

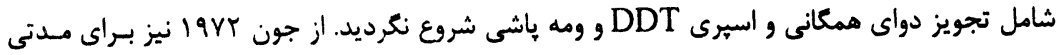

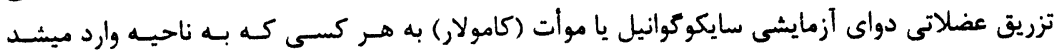

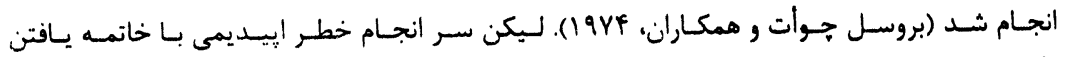
Diamond Rush

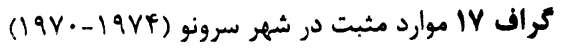

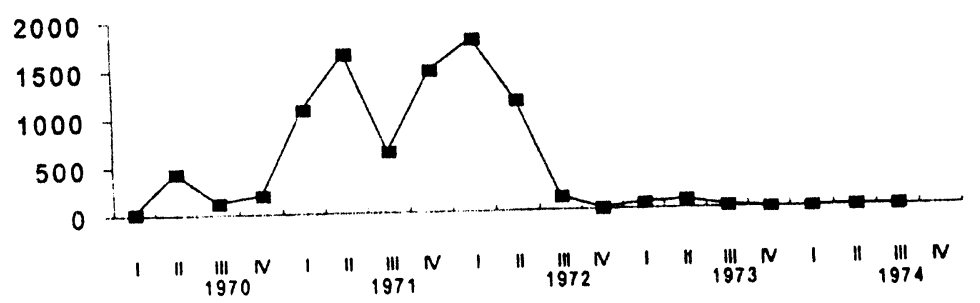

از دهه • أها در سواحل امريكاى مركزى در اوقيانوس اطلس، كنترول ملاريا در اثر آسيب بذيرى زيساد

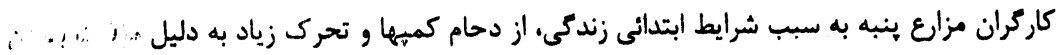




\section{WHO/MAL/98.1084}

0) صفحه

استخدام آنها دجار اشكال شد. در مقابل كنترول ملاريا در كثتزار هاى كيله در سواحل اتلانتيك بسـيار مؤثر بوده تا اينكه سقوط كشت ينبه در اوايل دهه •191 موجب اخراج وسيع كاركران مهاجرى كرديسد كه بعدأ نيروى كاركرى بسيار ارزانى را فراهم نمودند كه اجازه توسـعه كشستزار هـاى كيلـه در سـواحل اتلانتيك كوستاريكا و هند و راس را ميداد. اين موضوع از يكسو منجر بـه طفيـان هـاى كـانونى شـديد ملاريا در سواحل اتلانتيك و از سوى ديگر موفقيت كنترول ملاريا در سواحل اوقيانوس اطلسس كرديسد. اين تحولات با آمار هاى ملى ملاريا در كوستاريكا كه قبل از توسعه كشتزار هاى كيله به سطح بالايي از كنترول ملاريا دست يافت (كراف 11). در السلوادور كه سواحل اتلانتيـك نداشـت، ملاريـا بـا كـاهش كثت ينبه نايديد كرديد و در (كر اف 19) نشان داده شده اند. عـلاوه بسر تغييسرات الصـلاحى انسـان بـر محيط زيست و مهاجرى وى براى جستجوى كار، آفت اقتصادى و قحطى نيز از عوامل مهم تعين كننده

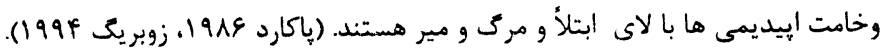

كراف 11 بروز ملارى در كوستاريكا در مقايسد با توليد كيله (199r -191)

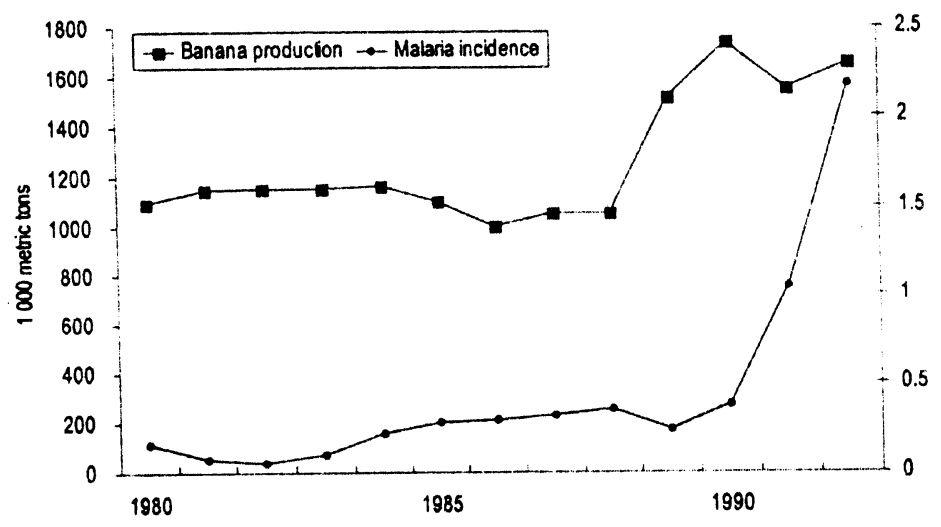

كراف 19 بروز ملاريا در السالوادور در مقايسه با توليد ينبه (•99 19191)

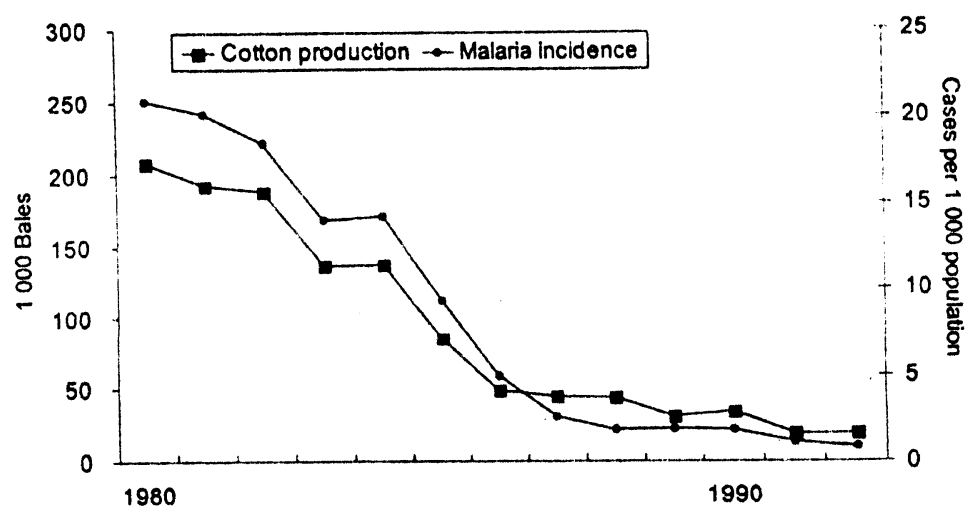




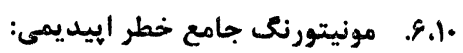

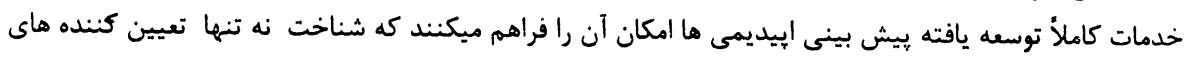

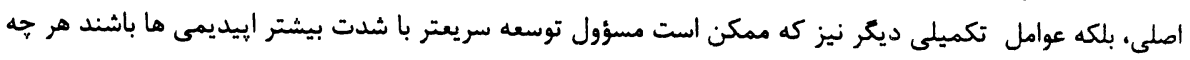
بيشتر تكامل نمايد.

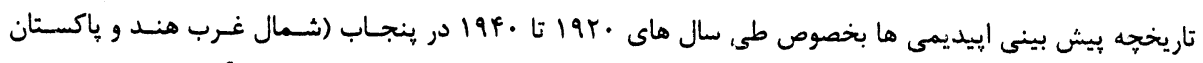

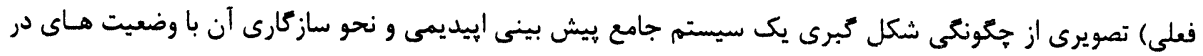

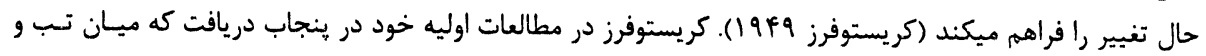

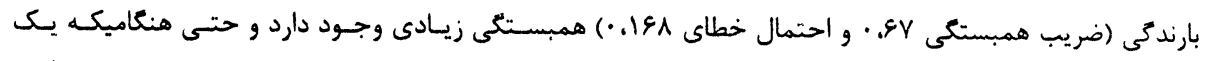

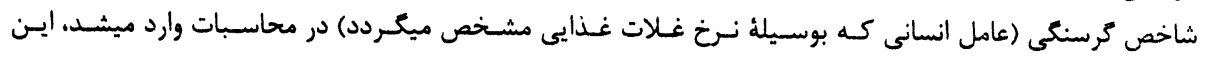

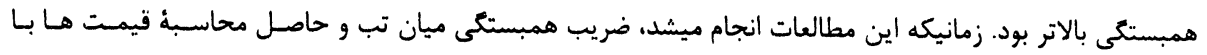

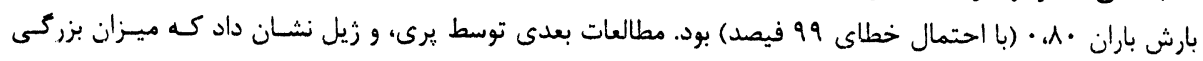

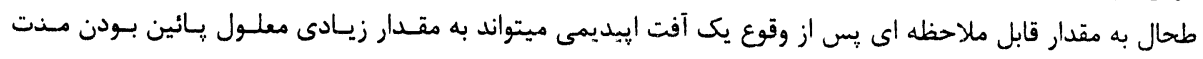

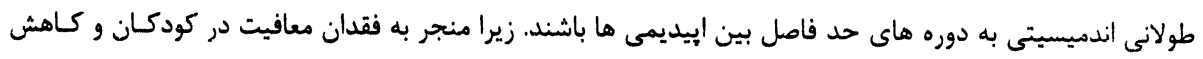

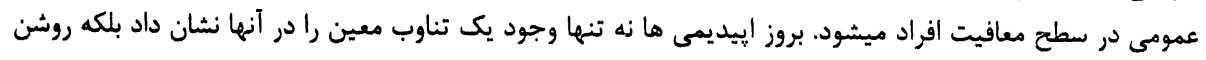

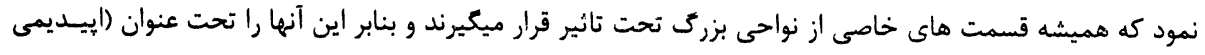

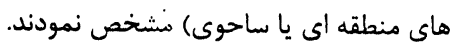

بر طبق نظريات زيل، بيش بينى اييديمى هاى ملاريا در پنجاب تا اوايل دهه • •190 بر اساس مطالعه جار فكتور ذيـل ادامه يافت:

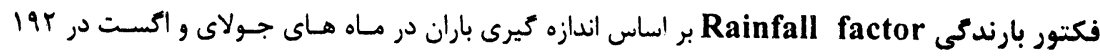

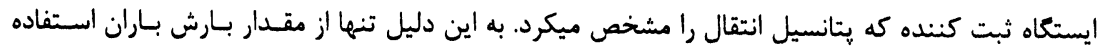

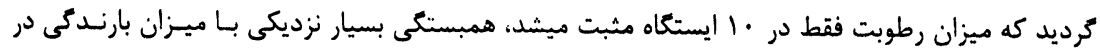

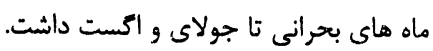
r. فكتور اندكس طحال Spleen index factor بر مبناى ميزان طحال كودكـان مدرسـه يسى، جمعبـت

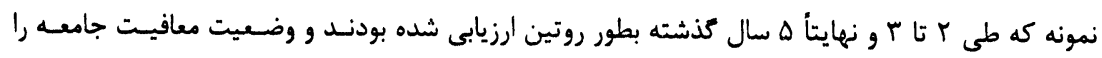

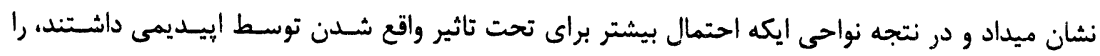
مشخص ميكرد.

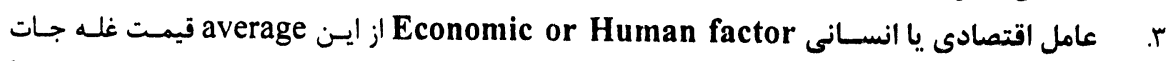
غذايى طى r سال كذشته به دست ميآمد. هر حند قحطى در فشار علل مستقيم إيديمى ها نبود امـا قويـا

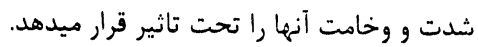

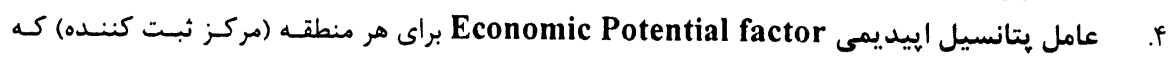

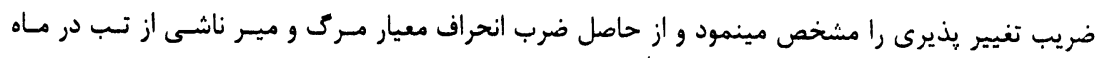

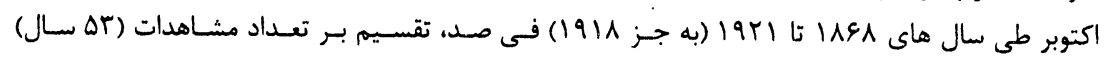

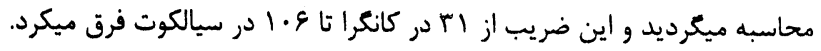


شهر ها بر حسب شدت إيديمى احير مشخص شده بودند و براى اندازه كيـرى شـدت واقعى يـك اييسديمى ععسين

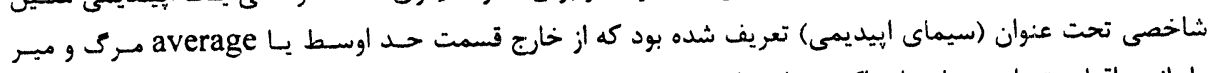

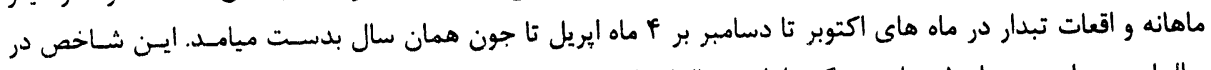

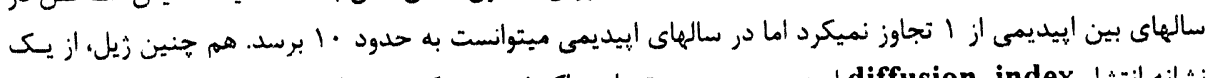

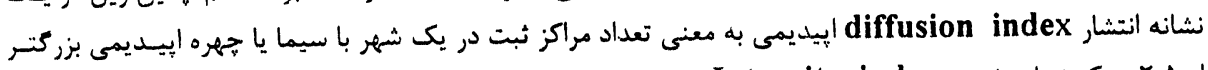

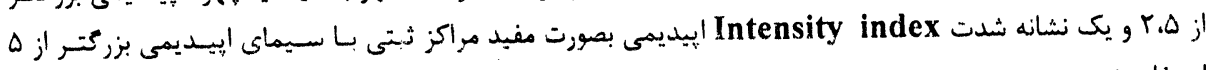
استفاده نمود.

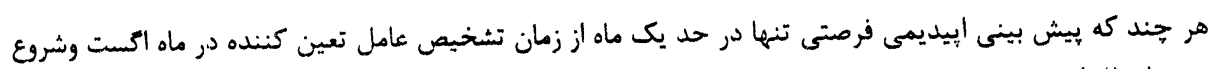

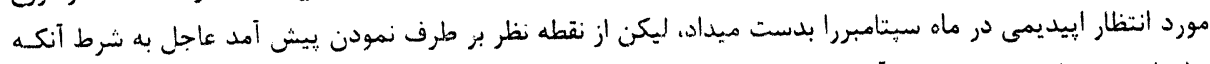

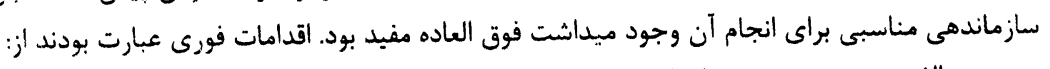

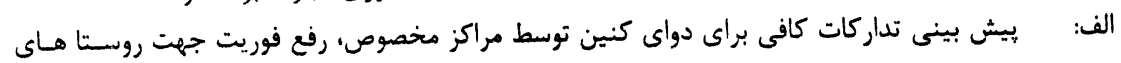

در معرض خطر

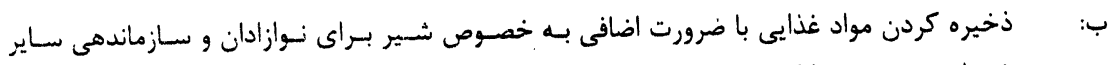

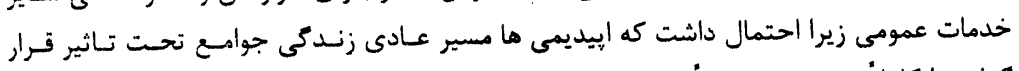

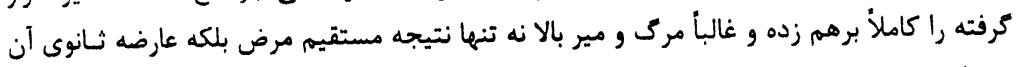
نيز باشد.

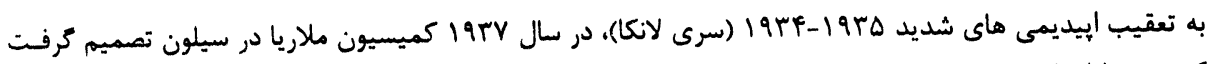

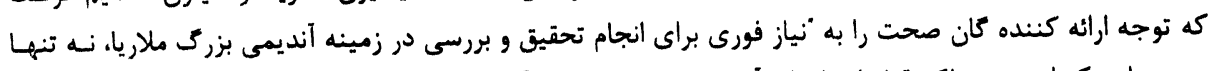

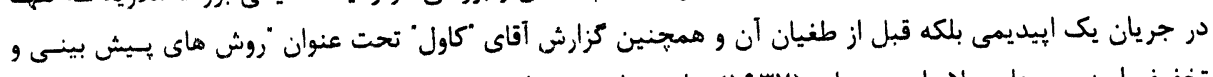

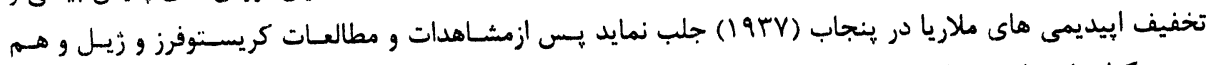

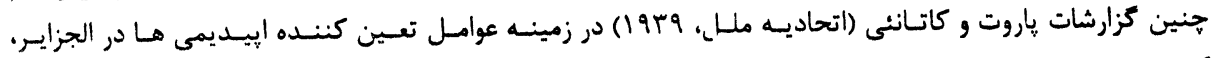

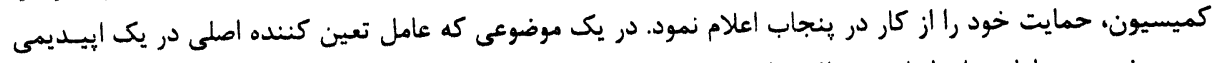

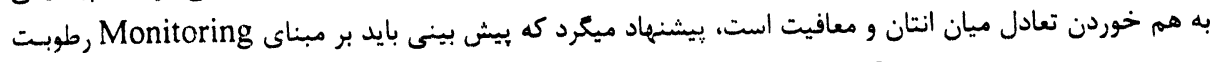

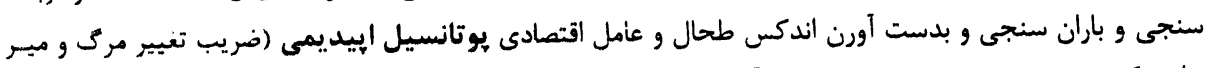

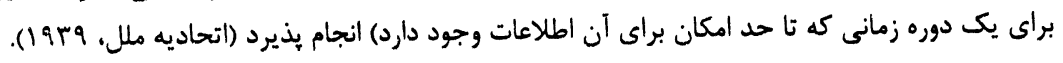

سيستم بيش بينى إييديمى در ينجاب به أرائه بيش بينى هاى مفيد خود تا زمان راه اندازي عمليات كسترد ده كنترول

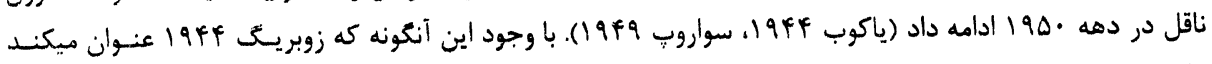

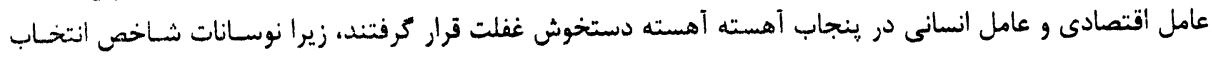

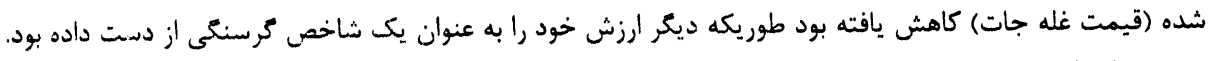

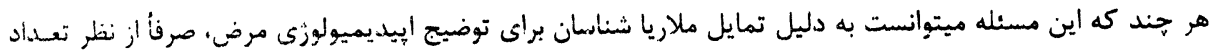

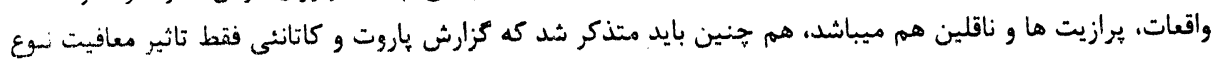


WHO/MAL/98.1084

صفr \&

ر ا بحث مينمود. مطالعه تفصيلى كاول و بيلى Premunition 19r9 حتى عامل انسانى را نيز ذكر نميكرد.

11. آمادكى فورىى و وقايه از الييديمى Emergency Preparedness and Epidemic Prevention)

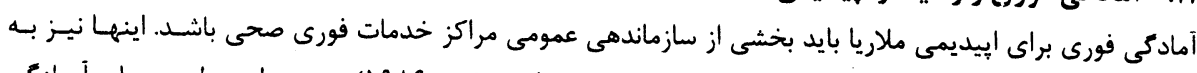

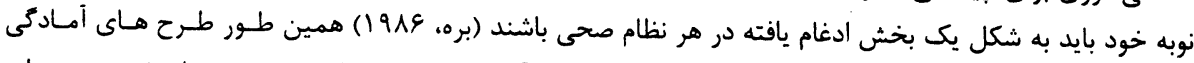

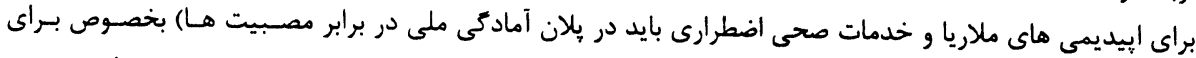

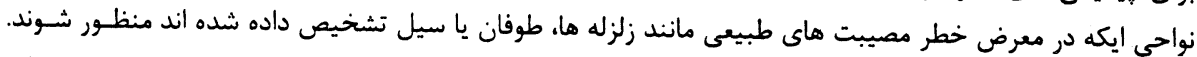

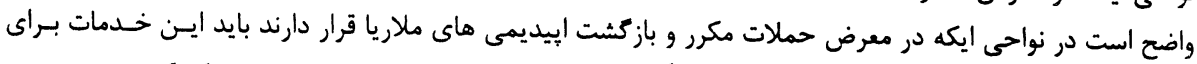

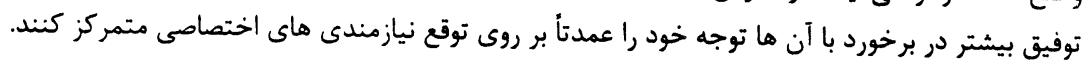

اصولا آمادكى براى اييديمى ملاريا بايد بر مبناى يكى درك إيديميولوزى از ملاريا و يا عوامل خطر اييديمى باشد. هـر

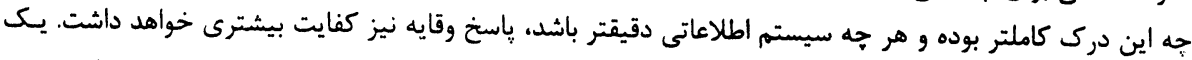

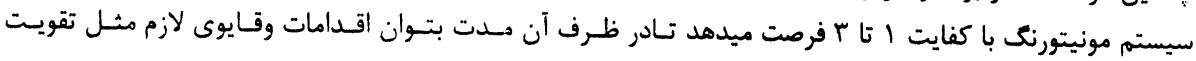

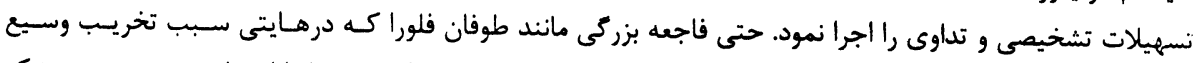

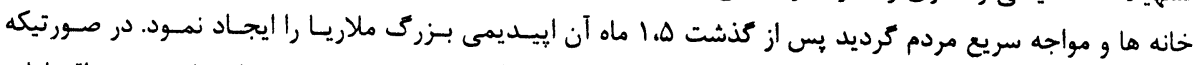

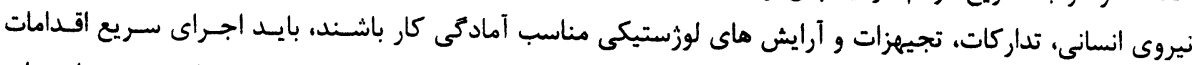

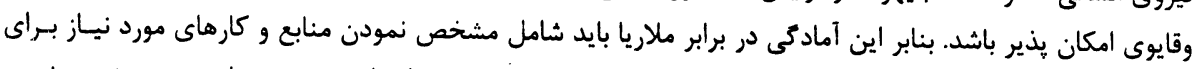

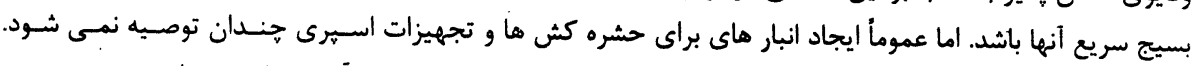

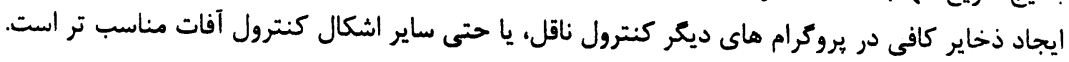

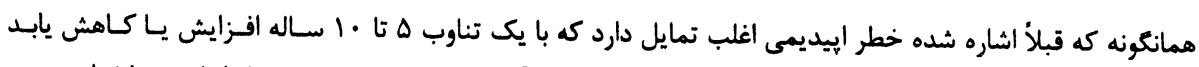

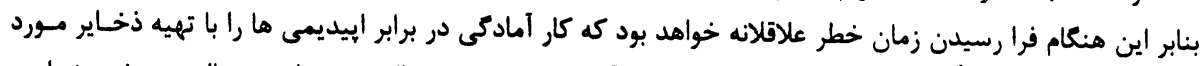

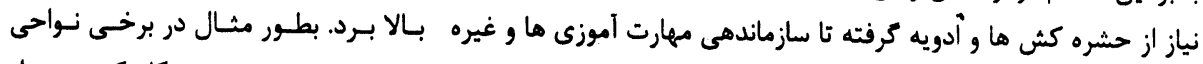

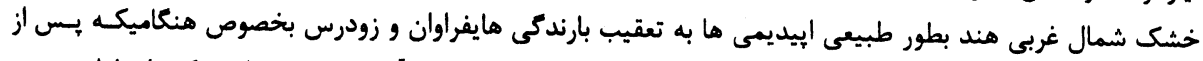

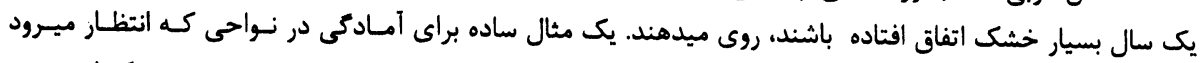

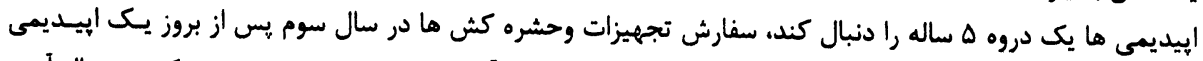

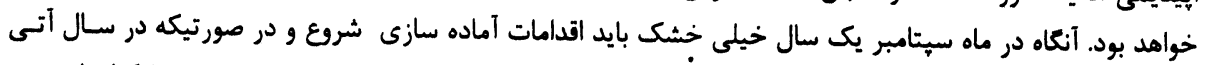

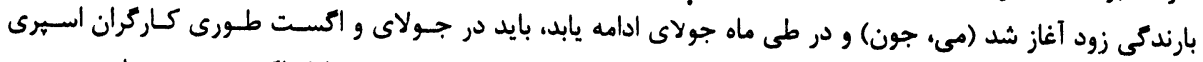

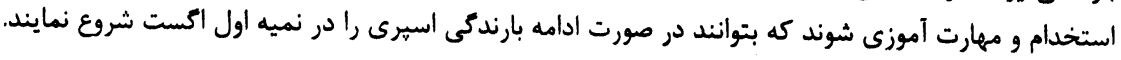

(11.11 اقدامات وقايوى:

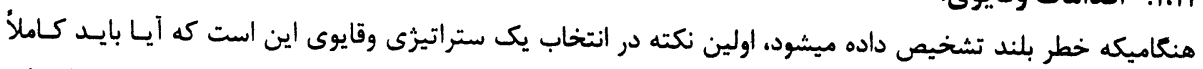

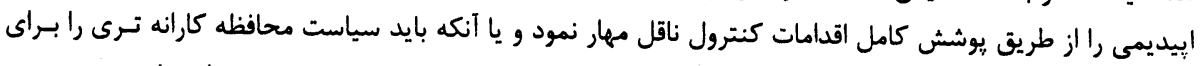

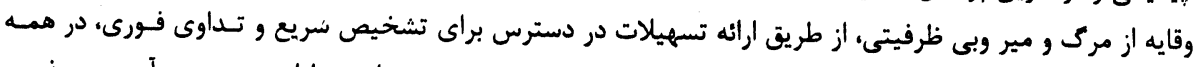

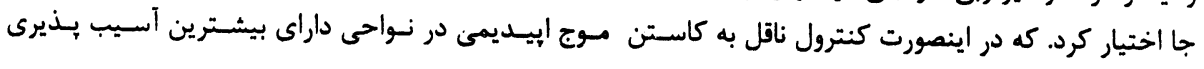




\section{WHO/MAL/98.1084}

\section{صفحه}

محدود خواهد كرديد. در انتخاب اين سياست ها يا هر نوع تركيب ديكرى از آنها در نواحى مختلف، بايـد مـوارد ذيـل مورد توجه قرار بكيرد:

$$
\begin{aligned}
& \text { يلازموديوم فلسيهارم، مقاومت دوايى وغيره } \\
& \text { • عملى بودن اجراى موفق راه هاى مختلف } \\
& \text { امكان ظرفيت موجوده براى وقايه از موج هاى آينده مودي موندي }
\end{aligned}
$$

هر جه كه وقايه كامل يك إيديمى بيشتر مورد نظر باشد، اغلب منجر به انتخاب جنان عمليات كنترول ناقل شده كـه

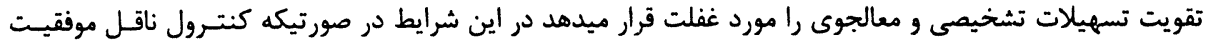

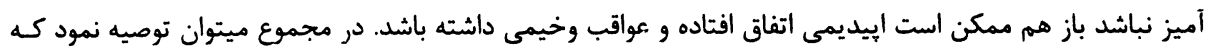

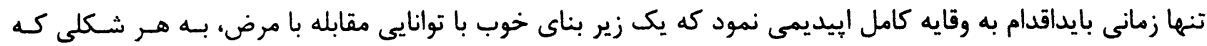

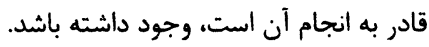

ازز لحاظ فنى، اقدامات وقايوى همان هاى خواهند بود كه در بخش كنترول إيبديمى بحث شدند اما اين امكسان وجـود

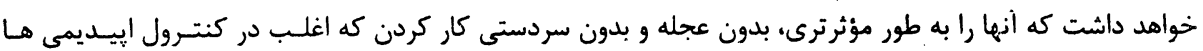
ديده ميشود، يلان اجرا نمود.

در مورد إيديمى هاى يلازموديوم ويواكس توصيه ديشود كه در زمستان يا اوايل بهار تداوى همكانى ضـد عـود بــاي

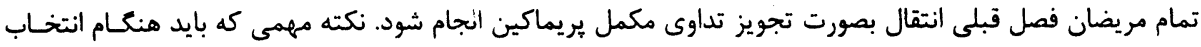

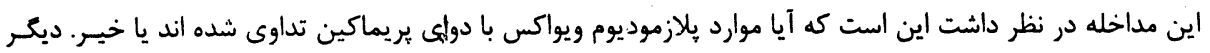

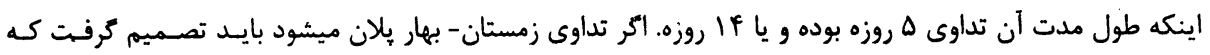

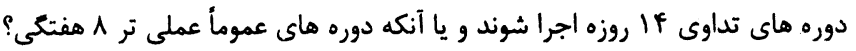

همانطوريكه در بالا اشاره شد، اقدامات وقايه مربوط به درجه آمادكى و فاصلة زمانى ميان تشخيص خطر تا آغاز مـورد

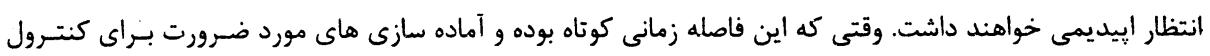

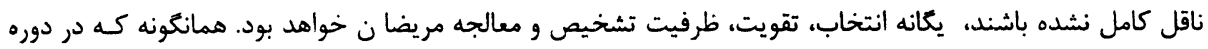

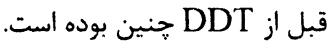


WHO/MAL/98.1084

صفح 


\section{References}

A.C.I.S. (1950). Statistical data on malaria morbidity and mortality provided to WHO.

Baptista, J.L. (1996). Subsidio para a historia do paludismo em S. Tome. Consideracoes sobre uma epidemia. Acta Medica portuguesa, 9, (7-9): 259-65.

BENN. E. C. (1947). Historical report of the Health division part II, A: Malaria Control programs. UNRRA, Italian Mission.

BINOL. K. (1983). Transmigration and health in connection with tropical disease in Indonesia. Southeast Asian journal of tropical Medicine and Hygiene, 14: 58-63.

BOUMA. M.J.. VAN DER KAAY, H.J. (1996). The EL Nino Southern Oscillation and the historic malaria epidemics on the Indian subcontinent and Sri Lanka: an early warning system for future epidemics? Tropical Medicine and International Health, 1, (1): 86-96.

BOWN, D.N., KNUDSEN, A.B., CHUKWUMA, F.O., ARATA, A.A., EZIKE, V.I., IWUALA, M.O.E.. BANG., Y.H. (1981). Indoor and outdoor ULV application of malathion for the extended control of anopheles and Aedes species in wooded rural communities in Easiern Nigeria. Mosquito News, $41: 136-42$.

BRES. P. (1986). Public Health Action in Emergencies Caused by Epidemics. A Practical guide. World Health Organization, Geneva.

BRUCE-CHWATT, L.J. (1973). Resurgence of Malaria and its Control. Journal of Tropical Medicine and Hygiene, 77, (4, suppl.): 62-6.

BRUCE-CHWATT, L.J. (1985). Essenial Malariology (second edition), William Heinemann Medical Books Ltd., London.

BRUCE-CHWATT, L.J., CLYDE, D.F., HAMON, J., NOGUER, A., LIANG, K.C., NAJERA, J.A. (1974). Report on Malaria Eradication in Venezuela. (October-November, 1974). PAHO/WHO mimeographed document, Washington, D.C.

CHAVASSE, D.C. \& YAP, H.H., eds. (1997). Chemical methods for the control of vectors and pests of public health importance. WHO unpublished documents, WHO/CTD/WHOPES/97.2.

CHRISTOPHERS, R. \& BENTLEY, C.A. (1908). Blacwater Fever. Sc. Mem. By Off. Of the Med. And San. Dept. Government of India. N.s. No. 35, [quouted in Christophers (1949)].

CHRISTOPHERS, R. \& BENTLEY, C.A. (1908). Blackwater Fever. Sc. Mem. By Off. Of the Med. And San. Dept., Government of India, n.s. No. 35, [quoted in Christophers (1949].

COLUZZI, A. (1961. L'eradicazione della malaria. Una sfida al mondo. Annali della sanita pubblica, 22: 241-53.

COVELL, G. \& BAILY, J.D. (1932). The study of a regional epidemic of malaria in Northern Sind. Records Malaria Survey of India, 3, (2): 279-322. 
CRUZ MARQUES, A. (1987). Human migration and the spread of malaria in Brazil. Parasitology Today, 3, (6): 166-70.

CULLEN, J.R., CHITPRAROP, U., DOBERSTYN, E.B., SOMBATWATTANANGKULK, (1948) An epidemiological early warning system for malaria control in Northern Thailand. Bulletin of the World Health Organization, 62, (1): 107-14.

DAGGY, R.H. (1059). Malaria in Oases of Estern Saudi Arabia. American Journal of Tropical Medicine and Hygiene, 8, (2, part 2): 223-91.

DE BEER, P., EL HARITH, A., DENG, L.L., SEMIAO SANTOS, S.J., CHANTAL, B., VAN GROOTHEEST, M. (1991). A Killing disease epidemic among displaced Sudanese population identified as visceral leishmaniasis. American Journal of Tropical Medicine and Hygiene, 44, (3): 283-9.

DELACOLLETTE, C., VAN DER STUYFT, P.. MOLIMA, K. (1996) Using community health workers for malaria control: Experience in Zaire. Bulletin of the world Health organization, $74,(4)$ : 423-30.

EDITORIAL (1996). Community financing or cost recovery: Empowerment or social dumping? Tropical Medicine and International Health, 1, (3): 281-2.

GABALDON, A. (1946). Las razones de endemicidad y de epidemicidad: dos nuevas medidas de interes malarimetrico. Tijeretazos sobre malaria, 10:19.

GILL, C.A. (1923). The prediction of malaria epidemics, with special reference to an actual forecast in 1921, Indian journal of Medical Research, 10: 1136-43.

GILL, C.A. (1928). The Genesis of Epidemics and the Natural History of Disease. Bailliere, Tindall and Cox, London.

GILLES, H.M. (1991). Management of severe and complicated malaria. A practical handbook. World Health Organization, Geneva.

HACKETT, L.W. (1949). Distribution of Malaria. In: Boyd, M.F. Malariology. W.B. Saunders Company, Philadelphia \& London. Pp. 722.48.

JENKINS, C.L. (1988). Health in the early contact period: A contemporary example from Papua New Guinea. Social Science and Medicine, 26, (10): 997-1006.

JULVEZ, J., MOUCHET, J., RAGAVOODOO, C. (1990). Epidemiologie historique du paludisme dans $\mathrm{I}^{\prime}$ achipel des mascareignes (Ocean indien). Annales de la societe belge de medicien Tropicale, 70, (4): 249-61.

KLIGLER, I. (1930). The epidemiology and control of malaria in palestine. The university of Chicago Press, Chicago. 
KROGSTAD, D.J., JOSEPH, V.R., NEWTON, L.H. (1975) . A prospective study of the effects of ultralow vouime (ULV) aerial application of malathion on epidemic Plasmodium falciparum malaria. IV. Epidemiologic aspects. Amierican Journal of Tropical Medicine and Hygiene, 24, (2): 199-205.

KONDRASHIN, A.V. (1987). Practical implications of population movements on epidemiology of malaria in South East Asia. Journal of communicable Diseases, 19:81-5.

KOUZNETSOV, R.L. (1989). Problems experienced in the recognition and management of recent malaria epidemics. WHO mimeographed document. MAL/EC19/89.14.

LEAGUE OF NATIONAS (1938). Methods of forecasting and mitigating malaria epidemics in India. Malaria Commission mimeographed document. No. C.H./Malaria/ 257 and C.H./Malaria/258.

LEAGUE OF NATIONS (1939). Factors connected with the outbreak of malaria epidemics in Algeria. Malaria commission mimeographed document. No. CH./Malaria/270.

LEPERS, J.P., DELORON, P., ANDRIAMAGATIANA-RASON, M.D., RAMANAMIRIJA, J.A., COULANGES, P. (1990a). Newly transmitted Plasmodium falciparum malaria in the central highland plateaux of Madagascar: assessment of Clinical impact in a rural community. Bulletin of the World Health Organization, 68, (2) 217-22.

LEPERS, J.P., FONTENILLE, D., ANDRIAMAGATIANA-RASON, M.D., DELORON, P., COULANGES, P. (1990b). Facteurs ecologiques de la recrudescence du paludisme a madagascar. Bulletin de la Societe de pathologie Exotique, 83, (3) 330-41.

LEPERS, J.P., FONTENILLE, D., RASON, M.D., CHOUGNET, C., ASTAGNEAU, P., COULANGES, P., DELORON, P. (1991). Transmission and epidemiology of newly transmitted falciparum malaria in the central highland plateaux of Madagascar. Annals of Tropical Medicine and Parasitology, 85, (3): 297-304.

MACODONALD. G. (1957). The epidemiology and control of malaria. Oxford University Press, London, New York, Toronto.

MADELEY, J. (1988). Malaria in the Solomons. World Health, June 1988: 14-5.

MAHESWARY, N.P., KHAN Z., MOLLA, F.R., HAQ, M.I. (1993). Incrimination of Anopheles annularis van der Wulp-1854 as an epidemic malaria vector in Bangladesh. Southeast Asian Journal of tropial Medicine and Public Health, 24, (4): 776-8.

MARIMBU, J., NDAYIRAGIJE, A., LE BRAS, M., CHAPERON, J. (1993). Evironnement et paludisme au burundi. A propos d'une epidemie de paludisme dans une region montagneuse non endemique. Bulletin de la societe de pathologie Exotique, 86, (5 part 2): $399-401$.

MASON, J., CAVALIE, P. (1965). Malaria epidemic in Haiti following a hurricane. American Journal of tropical medicine and Hygiene, 14, (4): 533-9. 
7. صفحه

MATHUR, K.K., HARPALANI, G., KALRA, N.L., MURTHY, G.G.K., NARASIMHAM, M.V.V.L. (1992). Epidemic of Malaria in Barmer District (Thar Desert) of Rajasthan during 1990. Inđian Journal of Malariology, 29: 1-10.

MATOLA, Y.G., WHITE, G.B., MAGAYUKA, S.A. (1987). The changed pattern of malaria endemicity and transmission at Amani in the Eastern Usambara mountains, North-eastern Tanzania. Journal of Tropical Medicine and Hygiene, 90: 127-34.

MISSIROLI, A. (1934). Lezioni sulla epidemiologia e profilassi della Malaria. Libraria Luigi Pozzi. Roma.

NAJERA, J.A. (1993). Tropical diseases, environment and development (with special reference to malaria and its control). X Giornata dell' Ambiente: Ambiente, Salute e Sviluppo (Roma, 5 giugno 1992), Rend. Acc. Naz. Lincei, 102: 65-83.

NARANJO, P. (1992). Epidemic hecatomb in the New World. Allergy Proceedings, 13, (5): 237-41.

ONORI, E., GRAB, B. (1980). Indicators for the forecasting of malaria epidemics. Bulletin of the World Health Organization, 58, (1): 91-8.

ONUIGBO, M.A.C. (1990). Diagnosis of typhoid fever in Nigeria: misuse of the widal test. . Transactions of the Royal Society of Tropical Medicine Hygiene, 84:129-31.

PACKARD, R.M. (1986). Agricultural development, migrant labor and the resurgence of malaria in Swaziland. Social Science and Medicine, 22, (8): 861-7.

PAHO/WHO (1993) Status of malaria Programs in the Americas, XLI Report, Washington, DC. Document CD37/INF/2 (Eng.) 16.8.93.

PAHO/WHO (1994) Status of malaria Programs in the Americas, XLII Report, Washington, DC. Document CSP24/INF/2 (Eng.) 30.8.94.

PARROT, L. \& CATANEI, A. (1939). Les Facteurs d' Apparition des Epidemies de Paludisme en Algerie. League of Nations mimeographed document reference (C.H./Malaria/270).

PINIKAHANA. J. \& DIXON, R. A. (1993). Trends in Malaria morbidity and mortality in Sri Lanka. Indian Journal of Malariology, 30, (2): 51-5.

PRASAD, R.N., VIRK, K.J., SHARMA, T., DUTTA, G.D. (1992). Malaria epidemic in Baniyani village, District Farrukhabad (U.P.) Indian Journal of Malariology, 29, (4): 219-24.

RAFFAELE, G., COLUZZI, A. (1949). Relazione sulla malaria nella provincia di Frosinone negli anni 1945-1948. L'epidemia malarica di Cassino. Rivista di Malariolgia, 28, (2): 61 106.

RAFFAELE, G., COLUZZI, A. (1953). Esperimenti d' interrzione della lotta antianofelica in alcune zone malariche. Rivista di Malariologia, 32, (4-6): 203-12. 
صنحه

RAZANAMPARANY, M., BOSMAN, A., RAVELMANANA, N., RANDRIAMIHARISOA, F., RAZAFIMANTSOA, L. (1989). The Malaria epidemic in Antananarivo observed from pediatric service "A" of the Befelatanana General Hospital, Parassitologia, 31: 89-99.

RICO-AVELLO Y RICO, C. (1950) La epidemia de paludismo de la postguerra Revista de Sanidad e Higiene Publica (Madrid), 24: 701-37.

ROSENBERG, R., MAHESWARY, N.P. (1982). Forest malaria in Bangladesh II. Transmission by Anopheles dirus. Am. J. Trop. Med. Hyg., 31: 189-91.

SAWYER, D. (1993). Economic and social consequences of malaria in new colonization project in Brazil. Soc. Sci. Med., 37, (9) 1131-6.

SHARMA, V.P \& MEHROTRA, K.N. (1986). Malaria resurgence in India: a critical study. Social Seience and Medicine, 22, (18): 835-45

SHARMA, Y.D., BISWAS. S., PILlAI, C.R., ANSARI, M.A., ADAK, T., DEVI, C.U. (1996). High prevalence of choroquine resistant Plasmodium Falciparm infection in Rajasthan epidemic. Acta Tropica, 62, (3): 135-41.

SHOUSHA, A.T. (1948). L'extermination d'une espece. Destruction de Anopheles gambiae en Haute-Egypte 1942-1945. Bulletin of the World Health Organization, 1, (2): 344-90.

SIVAGUANASUNDRAM, C., (1973). Reproduction rates of infection during the 1967-1968 $P$. vivax Malaria epidemic in Sri Lanka (Ceylon). Journal of Tropical Medicine and Hygiene, 76, (4): 83-6,

SMILLIE, W.G. (1927). Epidemic of malaria at Gantt impounded area, Covington County, Alabama, American Journal of Hygiene, 7: 40-72.

SMILLIE, W.G. (1927). Further studies of impounded area at Gantt, Albama. Southern Medical Journal, 20: 475-80.

SOPER, F.L. \& WILSON, D.B. (1943). Anopheles gambiae in Brazil, 1930 to 1940. The Rockefeller Foundation, New Yark.

SWAROOP, S. (1949) Forecasting of epdemic malaria in the Punjab, India. American Journal of Tropical Medicine, 29, (1): 1-17.

TAYLOR, R.T., SOLIS, M., WEATHERS, D.B., TAYLOR, J.W. (1975). A Prospective study of the effects of ultralow volume (ULV) aerial application of malathion on epidemic Plasmodium falciparm malaria. II Emtomologic and operational aspects. American Journal of Tropical Medicine and Hygiene, 24, (2): 188-92.

THOMSON, M.C., CO` NOR, S.J., MILLIGAN, P.J., FLASSE, S.P. (1996). The ecology of malaria - as seen from Earth-observation stellites. Annals of tropical Medicine and parasitology, 90, (3): 243-64. 
TIKASINGH, E., EDWARDS, C., HAMILTON, P.J., COMMISSIONG, L.M., DRAPER, C.C. (1980). A malaria outbread due to Plasmodium malariae on the Island of Grenda, Americañ Journal of Tropical Medicine and Hygiene, 29, (5): 715-9.

TUN-LIN, W., HTAY-AUNG, MOE-MOE, Sebastian, A., MYO-PAING, Myat-Myat-Thu (1987). Some environmental factors influencing the breeding of Anopheles balabacensis complex (dirus) in domestic wells in Burma. Journal of Communicable diseases, 19, (4): 291 9.

VEEKEN, H. (1993) Malaria and gold fever. British Medical Journal, 307, (Aug 14): 433-4.

VERDRAGER, J. (1995). Localized permanent epidmics: the genesis of chloroquine resistance in Plamodium falciparm. Souteast Asian. Journal of Tropical Medicine and public Health. 26, (1): 23-8.

VERLE, P., BINH, L.N., LIEU, T.T., YEN, P.T., COOSEMANS, M. (1996). Para Sight-F test to diagnose malaria in hypo-endemic and epidemic prone regions of Vietnam. Tropical Medicine and Parasitology, 1, (6): 794-6.

VILLALBA, J. de (1902). Epidemiologia espanola: o historia cronologica de las pestes contagios, epidemias y epizootias que han acacido en Espana desde la venida de los cartagineses hasta el ano 1801. Impernta de Don Mateo Repulles, Madrid.

WARSAME, M., WERNSDORFER, W.H., HULDT, G., BJORKMAN, A. (1995). An epidemic of plamodium falciparum Malaria in Balcad, Somalia, and its causation, Transactions of the Royal Society of Tropical medicine and Hygiene, 89: 142-5.

WIJESUNDERA, M.S (1988). Malaria Outbreaks in new foci in Sri Lanka. Parasitology Today. 4, (5): 147-50.

WORLD HEALTH ORGANIZATION (1951). Malaria conference in Equatorial Africa. WHO Technical Report Series, No. 38.

WORLD HEALTH ORGANIZATION (1974). WHO Expert Committee on Malaria. Sixteenth Report. Geneva, World Health organization. WHO Technical Report Series, No. 549.

WORLD HEALTH ORGANIZATION (1992). Global malaria control Strategy. Ministerial Conference on Malaria, Amsterdam, 26-27 October 1992. Document CTD/MCM/IM/92.3.

WORLD HEALTH ORGANIZATION (1995a). Management of childhood illness training course. WHO documents WHO/CDR/95.14 A to L.

WORLD HEALTH ORGANIZATION (1995b). Vector control for malaria and other mosquito-borne disease. Report of a WHO study Group. Geneva. WHO Technical Report Series, No. 857.

WHO/UNEP/ILO (1994). The WHO recommended classification of pesticides by hazard and guidelines to classification 1994-1995. WHO document WHO/PCS/94.2. 
WHO/MAL/98.1084

صفح 1 \%

YACOB, M., SWAROOP, S. (1944). The forecasting of epidemic malaria in the Punjab. Journal of the malaria Institute of India 5:319-35.

ZUBBRIGG, S. (1994). Re-thinking the "human factor" in malaria mortality: the case of Punjab, 1868-1840. Parassitologia, 36, (1-2): 121-33. 


\section{WHO/MAL/98.1084}

\section{ضمايم}

جدول الف: إييديمى هاى حقيقى

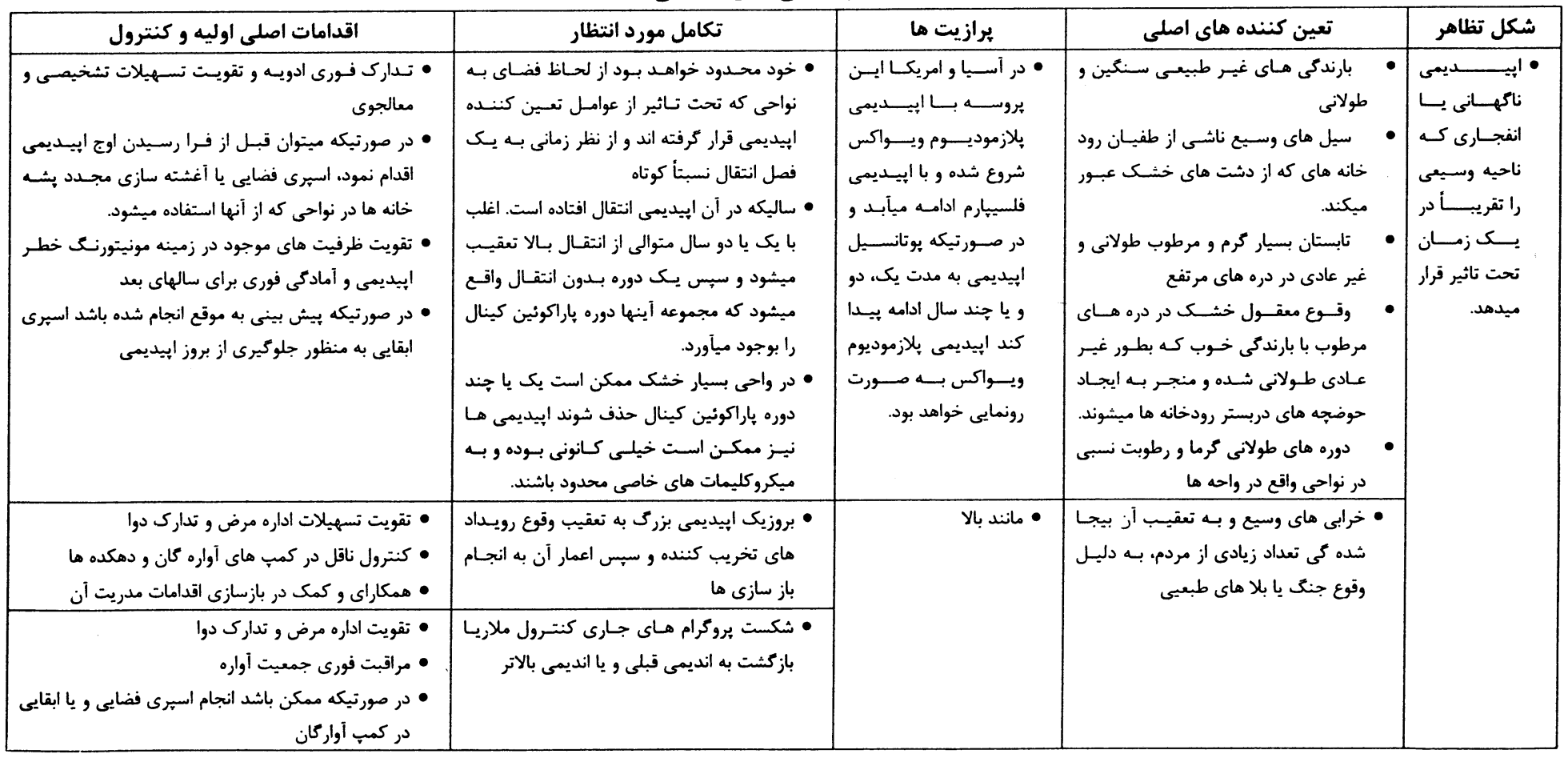




\section{WHO/MAL/98.1084}

\section{0}

\begin{tabular}{|c|c|c|c|c|}
\hline اقدامات اصلى اوليه و كنترول & تكامل مورد انتظار & ميرازيت ها & تعين كننده هاى اصلى & شكل تظاهر \\
\hline 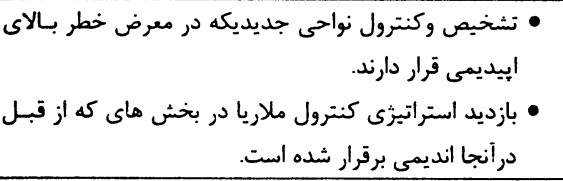 & 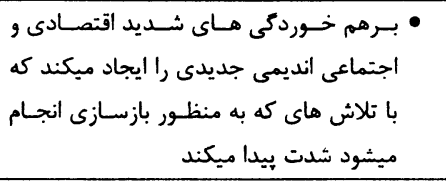 & . & & 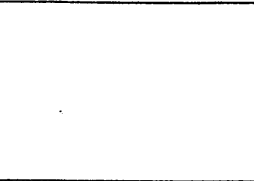 \\
\hline 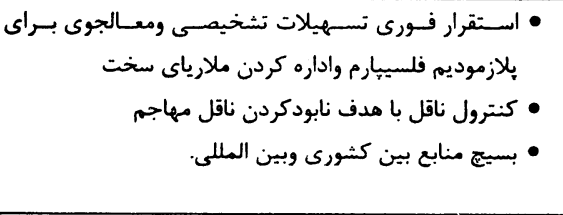 & 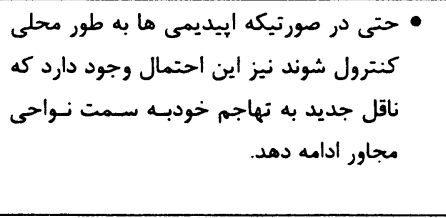 & 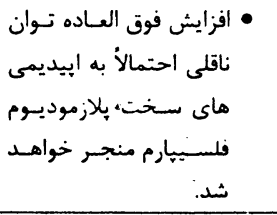 & 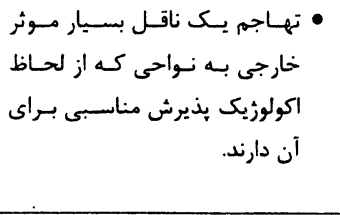 & \multirow{3}{*}{ 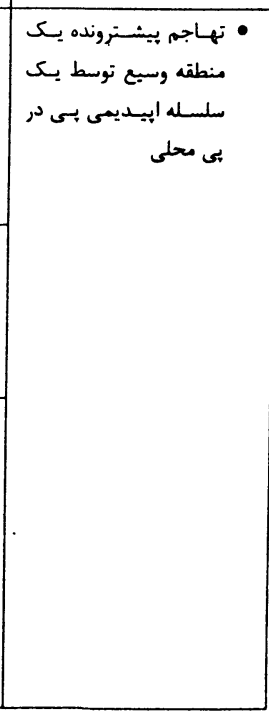 } \\
\hline 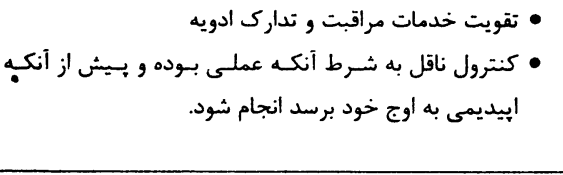 & • • دوره هاى دوره الى يك تا سه ساله آبيديمى & 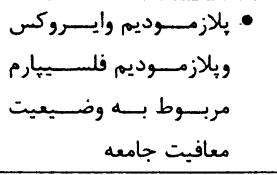 & 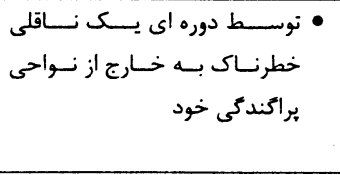 & \\
\hline 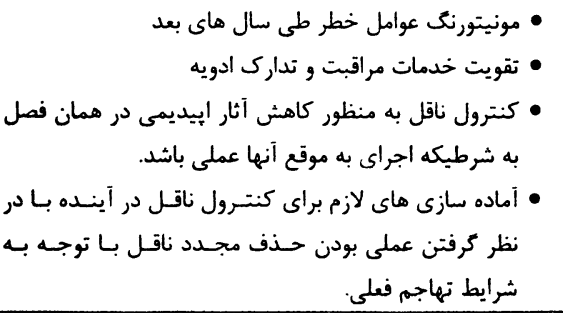 & 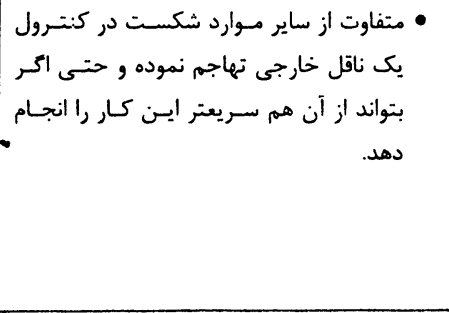 & 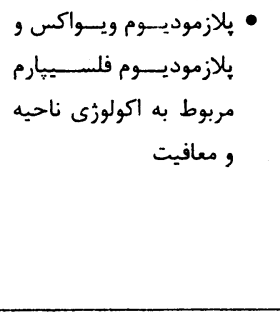 & 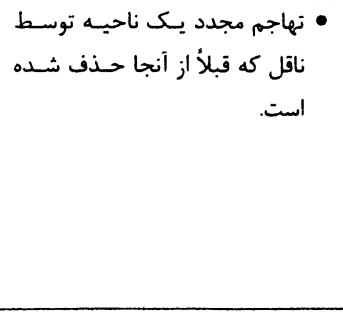 & \\
\hline
\end{tabular}




\section{WHO/MAL/98.1084}

77

\begin{tabular}{|c|c|c|c|c|}
\hline \multicolumn{5}{|r|}{ ادامه از صفحه قبل } \\
\hline اقدامات اصلى اوليه و كنترول & تكامل مورد انتظار & 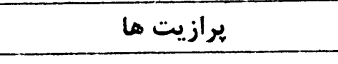 & تعين كننده هاى اصلى & شكل تظاهر \\
\hline • • كنترول ناقل : شيمويروفيلاكسى كمب هاى كار كرى & • • طفيله هاى محود ميان كاركران بـروزه هـاى & 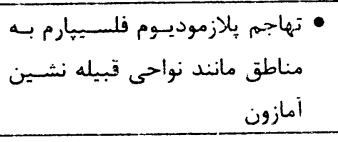 & & \\
\hline 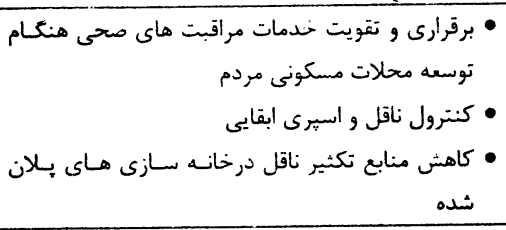 & • أسكان دهى جيديدى هاى مرتبط با هـم بـه دنبـال & & & \\
\hline 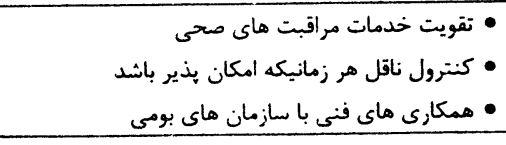 & • جمعيت بصاى اوليه البـديمى هـاى شـديد در بـين & & & \\
\hline 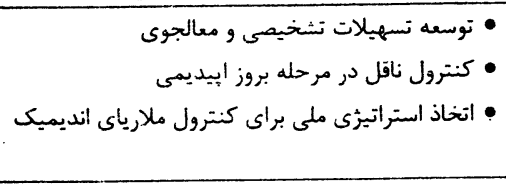 & 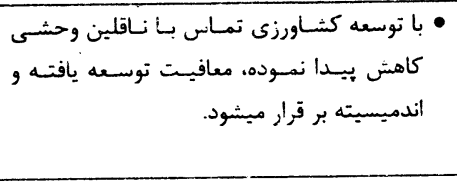 & 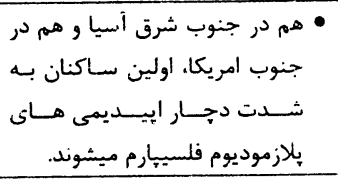 & • • ساكن شدن كشاورزان در نسواحى & 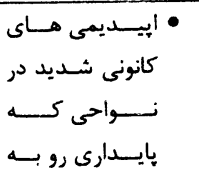 \\
\hline • ماند بالا & 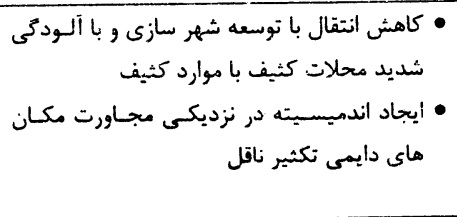 & 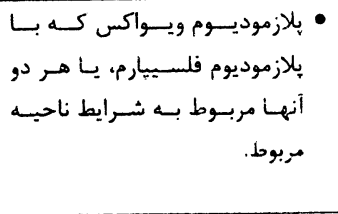 & 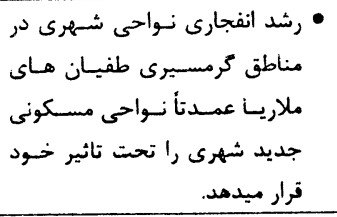 & افزايش است. \\
\hline
\end{tabular}




\section{WHO/MAL/98.1084}

iv

\begin{tabular}{|c|c|c|c|c|}
\hline 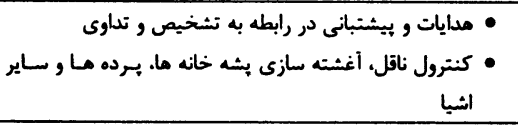 & 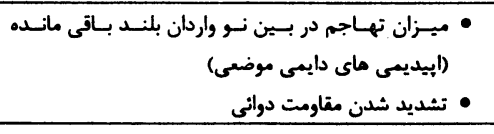 & 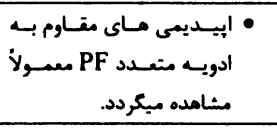 & 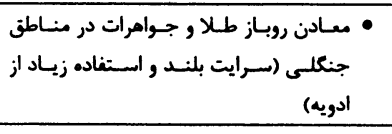 & 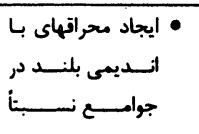 \\
\hline 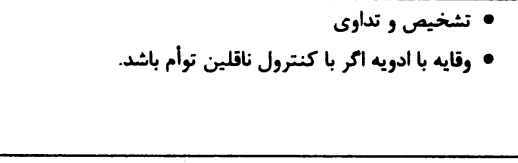 & • بودن فشار دوانى التخاب مقاومت دوائى كمتر به دليل بائين & 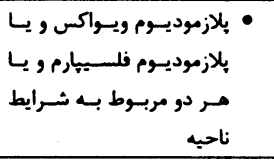 & • • كميهاى كساركرى (تحمبـات كرمستسيرى & 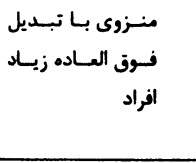 \\
\hline
\end{tabular}




\section{WHO/MAL/98.1084}

หง

جدول بازكشت يا شكست كنترول

\begin{tabular}{|c|c|c|c|c|}
\hline اقدامات اصلى اوليه و كنترول & تكامل مورد انتظار & هرازيت ها & تعين كننده هاى اصلى & شكل تظاهر \\
\hline • • • كنترول ناقل قبل از اوج فصـل انتقـال بـه منظـور كـاهـ & 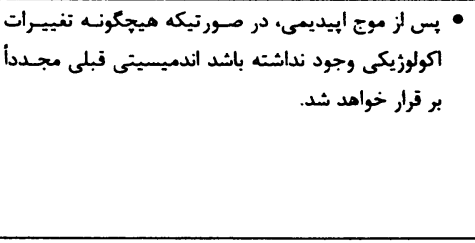 & 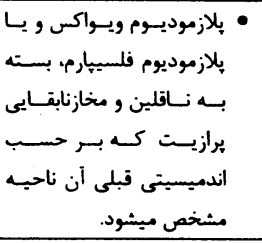 & 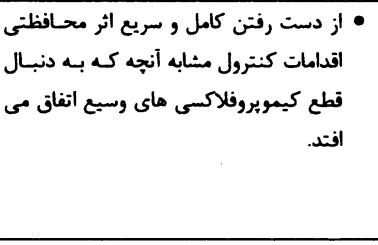 & \multirow[t]{2}{*}{ • • ن انتـــروع انفجــارى } \\
\hline 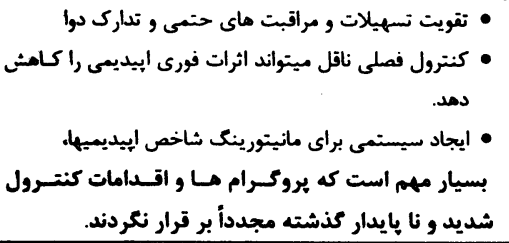 & 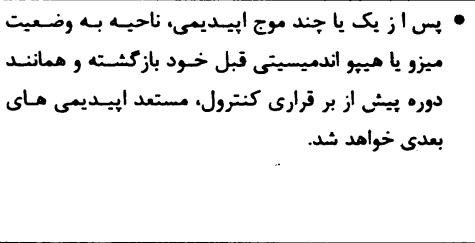 & 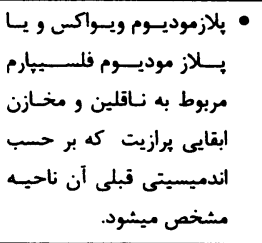 & 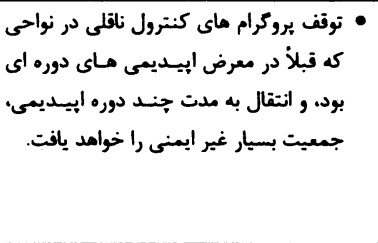 & \\
\hline 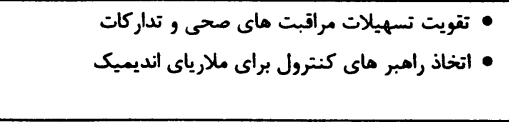 & 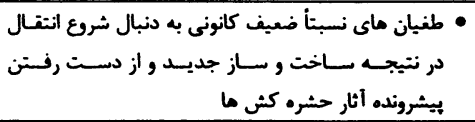 & • ماند بالا & 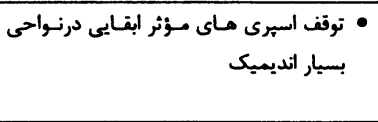 & • ب بر كثيت بيشـرونده \\
\hline
\end{tabular}

